University of Nebraska - Lincoln

DigitalCommons@University of Nebraska - Lincoln

USDA Forest Service / UNL Faculty Publications U.S. Department of Agriculture: Forest Service -National Agroforestry Center

2012

\title{
Interactive influences of ozone and climate on streamflow of forested watersheds
}

\author{
Ge Sun \\ USDA Forest Service, ge_sun@ncsu.edu \\ Samuel B. Mclaughlin \\ Oak Ridge National Laboratory \\ John H. Porter \\ University of Virginia, jporter@lternet.edu \\ Johan Uddling \\ University of Gothenburg, johan.uddling@bioenv.gu.se \\ Patrick J. Mulholland \\ Oak Ridge National Laboratory, mulhollandpj@ornl.gov \\ See next page for additional authors
}

Follow this and additional works at: https://digitalcommons.unl.edu/usdafsfacpub

Sun, Ge; Mclaughlin, Samuel B.; Porter, John H.; Uddling, Johan; Mulholland, Patrick J.; Adams, Mary B.; and Pederson, Neil, "Interactive influences of ozone and climate on streamflow of forested watersheds" (2012). USDA Forest Service / UNL Faculty Publications. 232.

https://digitalcommons.unl.edu/usdafsfacpub/232

This Article is brought to you for free and open access by the U.S. Department of Agriculture: Forest Service -National Agroforestry Center at DigitalCommons@University of Nebraska - Lincoln. It has been accepted for inclusion in USDA Forest Service / UNL Faculty Publications by an authorized administrator of DigitalCommons@University of Nebraska - Lincoln. 


\section{Authors}

Ge Sun, Samuel B. Mclaughlin, John H. Porter, Johan Uddling, Patrick J. Mulholland, Mary B. Adams, and Neil Pederson 


\title{
Interactive influences of ozone and climate on streamflow of forested watersheds
}

\author{
GESUN*,SAMUELB. MCLAUGHLIN†,JOHN H. PORTER+,JOHAN UDDLINGई, \\ PATRICK J. MULHOLLAND ${ }^{1}{ }^{2}$, MARY B. ADAMS $\uparrow$ and NEIL PEDERSON\| \\ *Eastern Forest Environmental Threat Assessment Center, USDA Forest Service, Venture II, Suite 300, Raleigh, NC 27606, USA, \\ †Oak Ridge National Laboratory, P O Box 2008, Oak Ridge, TN 37831, USA, †Department of Environmental Sciences, \\ University of Virginia, Charlottesville, VA 22903, USA, §Department of Biological and Environmental Sciences, University of \\ Gothenburg, Gothenburg, P O Box 461, SE 405 30, Sweden, ๆUSDA Forest Service, Northern Research Station, 241 Mercer \\ Springs Road, Princeton, WV 24740, USA, \|Tree Ring Laboratory, Lamont-Doherty Earth Observatory, Columbia University, 61 \\ Rt 9W, Palisades, NY 10964, USA
}

\begin{abstract}
The capacity of forests to mitigate global climate change can be negatively influenced by tropospheric ozone that impairs both photosynthesis and stomatal control of plant transpiration, thus affecting ecosystem productivity and watershed hydrology. We have evaluated individual and interactive effects of ozone and climate on late season streamflow for six forested watersheds (38-970 000 ha) located in the Southeastern United States. Models were based on 18-26 year data records for each watershed and involved multivariate analysis of interannual variability of late season streamflow in response to physical and chemical climate during the growing season. In all cases, some combination of ozone variables significantly improved model performance over climate-only models. Effects of ozone and ozone $\times$ climate interactions were also consistently negative and were proportional to variations in actual ozone exposures, both spatially across the region and over time. Conservative estimates of the influence of ozone on the variability $\left(R^{2}\right)$ of observed flow ranged from $7 \%$ in the area of lowest ozone exposure in West Virginia to 23\% in the areas of highest exposure in Tennessee. Our results are supported by a controlled field study using free-air concentration enrichment methodology which indicated progressive ozone-induced loss of stomatal control over tree transpiration during the summer in mixed aspen-birch stands. Despite the frequent assumption that ozone reduces tree water loss, our findings support increasing evidence that ozone at near ambient concentrations can reduce stomatal control of leaf transpiration, and increase water use. Increases in evapotranspiration and associated streamflow reductions in response to ambient ozone exposures are expected to episodically increase the frequency and severity of drought and affect flow-dependent aquatic biota in forested watersheds. Regional and global models of hydrologic cycles and related ecosystem functions should consider potential interactions of ozone with climate under both current and future warmer and ozone-enriched climatic conditions.
\end{abstract}

Keywords: climate, drought enhancement, forest water use, ozone, streamflow

Received 1 May 2012 and accepted 21 June 2012

\section{Introduction}

Forests cover $30 \%$ of the world's land surfaces, generate $50 \%$ of global net primary productivity, and play a significant role in sequestering atmospheric $\mathrm{CO}_{2}$ and regulating water supply (Bonan, 2008). Forests influence energy redistribution (Ryan et al., 2010) and evapotranspiration (Sun et al., 2011a,b), thus play a key role in the global hydrologic cycle (Jung, 2010). Studies have projected that increasing $\mathrm{CO}_{2}$ fertilization will

\footnotetext{
${ }^{1}$ Deceased.

Present address: S. B. McLaughlin, 76 Briar Patch Ln, Raphine, VA 24472, USA.

Correspondence: Dr. Ge Sun, tel. + 99515 9498, fax + 9195132 978, e-mail:ge_sun@ncsu.edu
}

increase water use efficiency and thus has the potential to increase ecosystem productivity and streamflow (Gedney, 2006). However, both carbon assimilation and forest water use efficiency can be negatively impacted by tropospheric ozone. Ozone is a very important global scale pollutant (The Royal Society, 2008) that acts both as greenhouse gas that contributes to global warming (Alley, 2007) and a phytotoxic pollutant that affects many interrelated forest physiological processes (Skarby et al., 1998; McLaughlin \& Percy, 1999; Samuelson \& Kelly, 2001). Tropospheric concentrations of ozone have doubled in the past century and are projected to follow increases in $\mathrm{NO}_{\mathrm{X}}$ emissions in the 21st century (Vingarzan, 2004). The proportion of the world' forests that experience phytotoxic levels of ozone ( $\geq 60 \mathrm{nl} \mathrm{l}^{-1} \mathrm{~h}$ ) is expected to increase from $24 \%$ in 1990 to $50 \%$ by 2100 (Fowler, 1999). Both empirical and mod- 
eling studies also show that tropospheric ozone can have negative impacts on carbon assimilation and growth and thus may limit the capacity of terrestrial vegetation to attenuate rising $\mathrm{CO}_{2}$ levels (Ollinger et al., 2002; Hanson et al., 2005; Friedlingstein, 2006; McLaughlin et al., 2007a,b; Noormets et al., 2010; Ren et al., 2011).

Although the capacity of ozone at ambient levels to reduce photosynthesis and growth of forest trees through internal biochemical changes is well documented (Skarby et al., 1998; McLaughlin \& Percy, 1999), reported ozone effects on stomatal conductance $\left(g_{\mathrm{s}}\right)$ have been much more variable in both direction and magnitude of change (Mansfield, 1998). Although reduced $g_{\mathrm{s}}$ has typically been observed in many controlled experiments with tree seedlings and saplings (Wittig et al., 2007), the relatively high ozone concentrations used, effects of containment and exposure of plants in chambers, and the relatively short duration of most experiments and measures of response necessarily limit the relevance of such studies for large trees in a forest environment. In addition, ozone has been found to increase $g_{s}$ and/or impair stomatal responsiveness and closure in response to a variety of environmental variables including drought (McAinsh et al., 2002; Pearson \& Mansfield, 1993), vapor pressure deficit (Grulke et al., 2007a,b; Maier-Maercker, 1999; MaierMaercker \& Koch, 1991; Uddling et al., 2009), light (Barnes and Brown, 1990; Reiling \& Davison, 1995; Grulke et al., 2002, 2004, 2007a,b; Paoletti \& Grulke, 2010), and $\mathrm{CO}_{2}$ concentration (Onandia et al., 2011). The consequences of such stomatal sluggishness can be increasing $g_{\mathrm{s}}$ and increased water use under conditions which normally induce stomatal closure (e.g. drought, high vapor pressure deficit and low light).

Recent studies with grassland species (Mills et al., 2009; Wilkinson \& Davies, 2009, 2010) have also shown ozone-induced increases in stomatal conductance even under reduced water supply (Wilkinson \& Davies, 2009; Hayes et al., 2012). An important mechanism for these responses is ozone-induced reduction in stomatal sensitivity to abscissic acid (ABA), a plant hormone stimulating stomatal closure under drought conditions. Reduced stomatal sensitivity to ABA has occurred in association with increased ethylene production, which is stimulated by ozone exposure (Wilkinson \& Davies, 2009, 2010).

Leaf gas exchange models currently employed in ecosystem models (Morales et al., 2005), as well as in dynamic global vegetation models (DGVM; Prentice et al., 2007) and general circulation models (GCM; Sellers et al., 1996; Pitman, 2003) assume a tight link between $g_{\mathrm{s}}$ and photosynthesis that acts to maintain an approximately constant intercellular to ambient $\mathrm{CO}_{2}$ concentration ratio (Ball et al., 1987; Lening, 1995).
These combined stomatal-photosynthesis models predict photosynthesis-mediated reduction in $g_{\mathrm{s}}$ by ozone, but do not account for direct effects of ozone on stomatal responsiveness to other environmental variables. They may thus be in error estimating the effects of ozone on plant water use, especially under conditions with limited soil water availability (e.g. Hayes et al., 2012). Importantly, impairment of stomatal responsiveness to environmental variables may occur at moderately elevated ozone concentrations and in the absence of negative effects on photosynthesis (Onandia et al., 2011).

Chronic and episodic droughts that affect soil water availability mediate plant-soil and plant-plant interactions on a worldwide basis (Schulze et al., 1987), and potential changes in drought frequency and severity have been considered a key scenario in projecting the ecological consequences of future climate change (Wigley et al., 1984; Zhao \& Running, 2010). Thus, possible increases in plant water use under current and/or future higher regional ozone concentrations are of particular concern for ecosystem hydrology and productivity under current warming trends.

Our previous studies detected ozone-induced amplification of drought effects on stem growth of mature loblolly pine trees (McLaughlin \& Downing, 1995). In subsequent studies in a mixed deciduous forest in East Tennessee (McLaughlin et al., 2007a,b) peak hourly ozone exposures per day averaged over days to weeks were found to play a significant role in reducing stem growth, stimulating sapflow (a measure of whole tree water use) increasing soil drying rate, and, over longer time frames, reducing streamflow of a nearby experimental watershed (McLaughlin et al., 2007b). Observed linkages between process level responses to ozone at the tree, stand, and watershed levels led to the present study to explore the magnitude and consistency of these relationships across forested watersheds at a regional scale. Our working hypothesis was that episodic increases in ambient ozone concentrations in the southeastern US study region would lead to increases in forest leaf canopy conductance, increases in ecosystem-level evapotranspiration, reduced soil moisture, and ultimately reduced late season (August-October) streamflow.

\section{Materials and methods}

In the present study, we have analyzed hydrologic response to ozone and climate variables over time periods of 18-26 years for six watersheds located in the Appalachian states of Tennessee (Walker Branch and Little River), North Carolina (Cataloochee Creek), Virginia (James River and New River), and West Virginia (Fernow Experimental Watershed; Fig. 1). All watersheds were predominantly forested with mixed deciduous forests and catchment size ranging from 38 ha (Walker Branch Watershed in Oak Ridge, Tennessee) to 


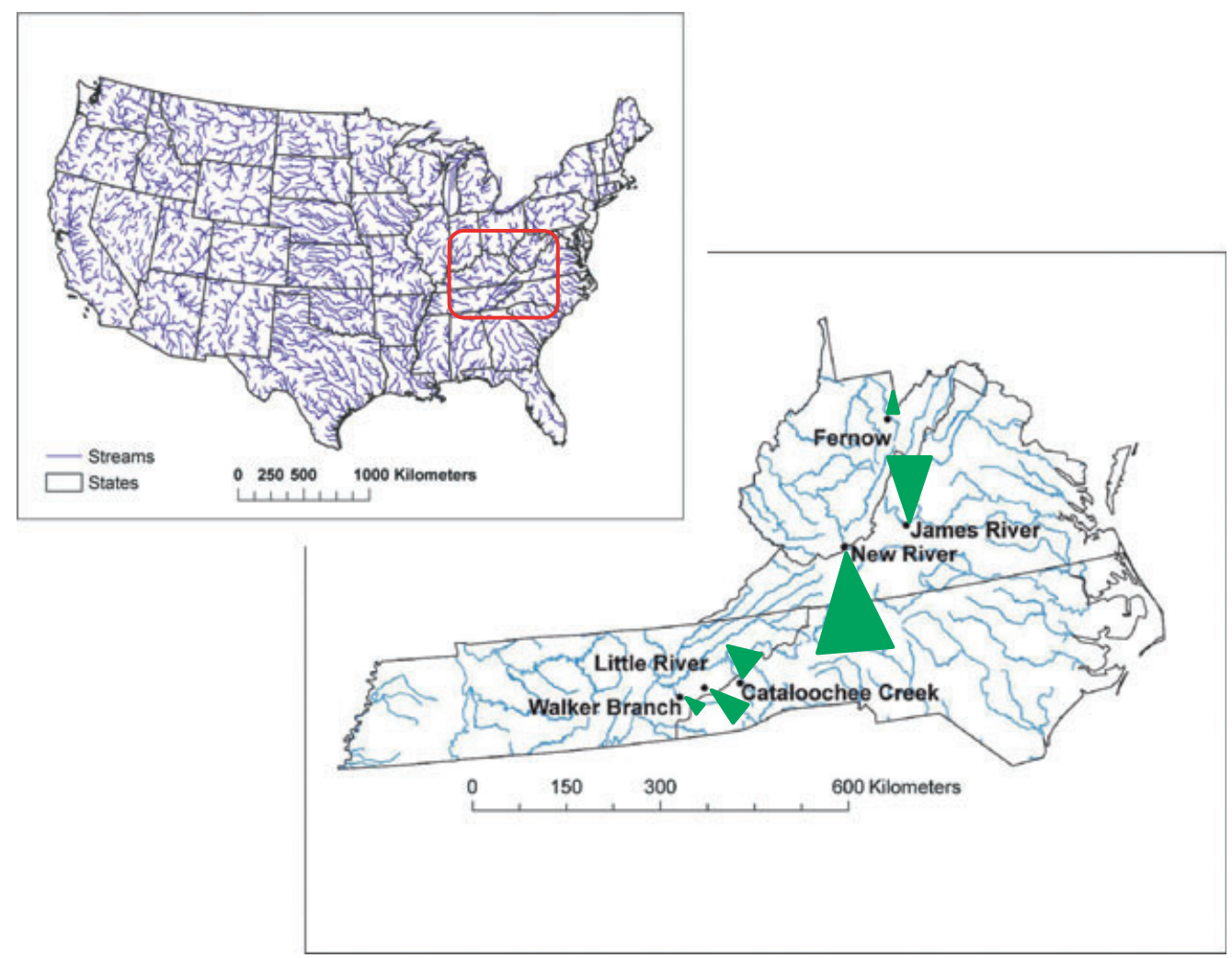

Fig. 1 Watershed locations in the southern Appalachian states of Tennessee, North Carolina, Virginia, and West Virginia.

970000 ha (New River watershed [NRWS] in Virginia and West Virginia. See Data S1 and Table S1 (Supporting information) for more detailed watershed descriptions, sources of climate and ozone data and a summary of environmental data for each watershed. We have used average monthly flow over the interval August through October, to represent the seasonal low flow conditions (Smakhtin, 2001) for the study region. The August through October streamflow was the focus of these analyses because it is a period of low rainfall when streamflow is most sensitive to tree transpiration, a major part of total watershed evapotranspiration. During this time, soil moisture and groundwater are primary sources of streamflow and both are responsive to cumulative tree water use over the entire growing season. Several other flow intervals, ranging from minimum weekly flow to growing season (April through October) flow were examined and found to be useful indicators, but are not reported here.

\section{Model development}

We have developed multivariate linear regression models to systematically analyze annual variations in late season streamflow in response to typically 7-11 environmental variables. We used 'best subset regression' techniques (Kleinbaum et al., 1998) to evaluate combinations of both ozone and climate variables and precedent time intervals as predictors of annual late season streamflow. Exploratory analyses indicated that neither nonlinear models nor Principal Components Analysis improved the detection and partitioning of environmental effects in the linear regression models we present here. Best Regression analysis examines model structure and associated performance at successively more complex levels $(n=1$ to $n=\mathrm{x})$ to identify the strongest combination of predictor variables for describing annual streamflow for each watershed over time. In our analyses we started with the single best $(n=1)$ predictor variable and then defined the best possible combinations of variables (and models) as $N$ was increased to a level at which model fit was no longer improved by further addition of candidates from the available predictor variable pool. The selection process minimizes covariance among selected variables by using 'strongest predictive gain' as the criterion for including each new variable in the current mix of variables included with each successive increase in model complexity.

The candidate environmental variables considered in these analyses were developed to describe potentially relevant combinations of physical and chemical climate and seasonal phenology of forests across the region. Climatic variables included monthly values of temperature, precipitation, ozone exposure, and Palmer Drought Severity Index (PDSI; Table 1). Both the timing and duration of forest canopy development were also considered in selecting the most appropriate time intervals for influencing streamflow. The most frequent intervals examined included April through October (the interval of active canopy retention), July through September, and August through October. PDSI, a hybrid index based on antecedent precipitation, temperature, and potential evapotranspiration demand, was included as it is a well-established indicator of 
Table 1 Definition and nomenclature of terms in watershed models

\begin{tabular}{|c|c|c|}
\hline Parameter & & Units \\
\hline \multicolumn{3}{|l|}{ Streamflow } \\
\hline F810 & Mean monthly stream flow from August to October & $\left(\mathrm{mm} \mathrm{month}{ }^{-1}\right.$ \\
\hline \multicolumn{3}{|l|}{ Ozone exposure } \\
\hline $\mathrm{O}_{3} \mathrm{MxH}$ & Monthly mean daily maximum hourly ozone concentration & $\left(\mathrm{nl} \mathrm{l}^{-1}\right)$ \\
\hline $\mathrm{O}_{3} \mathrm{AOT} 60$ & Monthly sum of hourly $\mathrm{O}_{3}$ exposures above $60 \mathrm{ppb}$ & $\left(\mu \mathrm{l}^{-1} \times \mathrm{h}\right)$ \\
\hline $\mathrm{O}_{3} \mathrm{SumO} 60$ & Monthly sum of hourly $\mathrm{O}_{3}$ exposures at or above $60 \mathrm{ppb}$ & $\left(\mu \mathrm{l}^{-1} \times \mathrm{h}\right)$ \\
\hline \multicolumn{3}{|l|}{ Temperature } \\
\hline TMP & Monthly mean daily temperature & $\left({ }^{\circ} \mathrm{C}\right)$ \\
\hline \multicolumn{3}{|l|}{ Precipitation } \\
\hline PPT & Monthly mean daily precipitation & $\left(\mathrm{mm} \mathrm{d}^{-1}\right)$ \\
\hline \multicolumn{3}{|l|}{ Drought } \\
\hline PDSI & Monthly mean Palmer Drought Severity Index & None \\
\hline WDF & Monthly mean water deficit & $\mathrm{mm}$ month $^{-1}$ \\
\hline \multicolumn{3}{|c|}{$\begin{array}{l}\text { Monthly mean is defined by the suffix with the initiating and concluding months in the series; } 410=\text { April-October, } \\
59 \text { = May-September, etc. }\end{array}$} \\
\hline \multicolumn{3}{|l|}{ Interaction terms } \\
\hline $\mathrm{O}_{3} \mathrm{M} \times \mathrm{H} \times \mathrm{PDSI}$ & Products of $\mathrm{MaxHO}_{3}$ and PDSI for intervals 410, 59, and 79 & \\
\hline SumO6 × PDSI & Product of $\mathrm{O}_{3}$ SumO60 and PDSI for interval 410 & \\
\hline
\end{tabular}

regional soil water stress in global change studies (Zhao \& Running, 2010). We also examined vapor pressure deficit and solar radiation as predictors of watershed yield at the 39-ha Fernow watershed that had complete climatic data. Neither vapor pressure deficit nor solar radiation significantly improved model performance or estimates of ozone and ozone $\times$ climate interactions of models that included PDSI for that site.

Ozone variables were derived from hourly data over the same monthly intervals as climate variables and were developed to capture three significant aspects of ozone exposure that provide indicators of potential phytotoxicity: these included summed absolute hourly values at or above $60 \mathrm{nl} \mathrm{l}^{-1}$ (SUM06); summed exceedances of a $60 \mathrm{nl} \mathrm{l}^{-1}$ threshold (AOT60); and finally averages of peak hourly concentration per day $(\mathrm{MxH})$. The values were derived for a $24 \mathrm{~h}$ day in all cases. Other ozone thresholds, including $40 \mathrm{nl}^{-1}$ were also examined and found to be useful indicators of ozone stress (see Data S1, Fig. S1, Fig. S2). In addition, four product terms were developed to evaluate the potential amplification of drought stress by ozone exposure as previously reported (McLaughlin et al., 2007a). Combinations of ozone and PDSI included in all of these interaction variables were those that were frequently related to streamflow on an individual basis. These terms were products of $\mathrm{MxHO}_{3}$ and PDSI over three time intervals (April-October, May-September, and July-September) and SUM06 (April-October).

All predictor variables were expressed as selected combinations of monthly averages for overlapping 2 to 7-month intervals during April to October. The same time intervals were used for each of the three climate and three ozone variables evaluated. The predictor variables included in each model were initially evaluated by developing the best preliminary models based on the strongest climate-based predictors of flow, and then the strongest ozone-related predictors of flow.
The capacity of added ozone terms to improve model predictive capacity of climate-only models was verified quantitatively and statistically at all stages of these analyses. The variables included in the final models were selected by best regression analyses from a list comprised of equal numbers of the strongest predictors of flow from both categories of variables. The ozone $\times$ climate variables were included in each pre-selection subset.

\section{Model validation and covariance analysis}

We have evaluated statistical integrity, strength, and consistency of all regression models developed using several criteria. First, because many of the environmental variables we used are inter-correlated through their linkages to temperature driven climate, we performed several tests to quantify and limit the influence of covariance on both model form and fit to the data. Second, to test for influences of sample size on model parameterization, we evaluated the consistency of model composition and predictive capacity when they were developed from subsets of data within the same historical record. Third, we evaluated predictive capacity of models of varying complexity to accurately fit to streamflow data from other watersheds within the study region. Finally, we used both growth patterns of mature trees and measurements of canopy water use of younger tree stands to test mechanistic aspects of the underlying hypothesis for these studies, that ambient ozone levels in the region were sufficiently high to increase forest water use, a prerequisite for reduced stream flow.

Covariance among predictor variables was addressed by statistically isolating the effects of ozone, climate, and climate $\times$ ozone interactive terms on model performance by multiple-partial correlation (MPC) analysis (Kleinbaum et al., 1998) and by assessing temporal autocorrelation that could 
lead to spurious results because of noncausative association of parallel trends. Low levels of serial autocorrelation were verified for both flow and physical climate data by testing for the correlation between actual and 1-year lagged data within each series using Pearson correlation analysis.

To ensure that we were not simply over-fitting the models, where a large pool of potential input variables and a limited number of observations could result in spurious models, we evaluated the form and strength of models developed by splitting the data into halves and evaluating the consistency of models developed from each of the two independent halves. We found a high consistency (similar $R^{2}$ and similar specific predictor variables included) of models from the split data halves, both with each other and with a model developed from the whole data set. We therefore focused our analysis on models based on the full data set for each watershed.

The influence of covariance among predictor variables in developed streamflow models was addressed by isolating and individually quantifying the unique contributions of ozone, climate, and ozone $\times$ climate interactions to overall model performance for each watershed model developed using MPC analysis (Kleinbaum et al., 1998). This technique measures predictive power lost from the complete model by subtracting the effects of each variable class (ozone or climate) from overall model performance with that class included. The significance of contributions of each variable class was then tested with a partial $F$-test for statistical significance to overall model $R^{2}$. To further isolate ozone and climate effects, partial correlation coefficients were also determined for each variable included in each watershed model. This approach evaluated influences of each variable on streamflow with all other variables held constant. Summed effects of all variables within a class, which sometimes included positive and negative coefficients for the same type of variable over time, were also determined to measure the net effect of all variables of that class on streamflow.

\section{Interregional comparisons of model performance}

In developing models of each of the six watersheds evaluated in this study, we have sought to maximize model performance by selecting the combinations of predictor variables that provided the best performance (highest $R^{2}$ adj and highest statistical significance) for each watershed. We have also evaluated how well these individual watershed models might fit the data from other watersheds within the approximate $125000 \mathrm{~km}^{2}$ area study region. To do this we used a less complex seven variable 'universal model', to assess model fit to data from other watersheds within the region. The universal model was based on definition of the strongest predictor variables derived from the Walker Branch Watershed. This model was then parameterized for each of the remaining watersheds. Parameterization involved developing a linear regression model using Walker Branch Watershed (WBWS) input variables with the actual environmental and flow data for each respective watershed.

A second method of evaluating the relative importance of climate and ozone variables as contributors to annual varia- tions in streamflow patterns involved a differential analysis of the input variables contributing most significantly to yearly differences in flow between two comparison watersheds. The two watersheds chosen were WBWS and James River Watershed (JRWS), representing, respectively, relatively higher and lower ozone exposures within the watershed set we examined. Here, the patterns of year to year differences in normalized annual flow between the two watersheds over time were analyzed using linear regression against annual differences in values of environmental input parameters between the two watersheds. Relative contributions of climate and ozone to observed flow differences were then quantified and tested statistically (See Data S1, Table S2).

\section{Cross-scale model verification with dendroecological data and FACE experiment}

Tests of interrelationships among tree and watershed responses to climate and ozone involved two approaches: (1) dendroecological analyses involving parameterization and cross comparisons of a multi-species model of annual tree growth derived from mature trees in Southwest Virginia with the streamflow data and model for the 2100 sq. mile James River watershed from the same region, and (2) measurements of seasonal patterns of canopy level water use of mixed aspenbirch stands under controlled ozone levels using free-air concentration enrichment (FACE) methodology.

Dendroecological analyses of linkages between tree growth and stream flow. The only direct role that ozone can play in affecting watershed scale streamflow is through impacts on tree water use. As a further test and validation of those relationships we examined a 20-year growth record for five tree species from an area within the regional air shed of the James River Watershed. The growth data were derived from 175 increment cores (unpublished data). Sampled trees were from high elevation sites (typically $\geq 1000 \mathrm{~m}$ ) from the Blue Ridge Mountains of Virginia and $30-60 \mathrm{~km}$ northeast of Buchanan, VA, the gauging station for the James River Watershed. The average tree age at coring was 170 years. Five species were included: red oak (Quercus rubrus), chestnut oak (Quercus prinus), pignut hickory (Carya glabra), and yellow poplar (Liriodendron tulipifera) as well as shagbark hickory (Carya ovata), Four were of the same species or genus included in our previous mechanistic study of ozone effects on tree growth and water use in Tennessee (McLaughlin et al., 2007a). The test applied in this case was development of a growth model of the five species mean growth chronology from candidate predictor variable subsets used in the development of regional streamflow models. Dendroecological analyses involved parameterization and cross comparisons of a multi-species model of annual tree growth derived from mature trees in Southwest Virginia with the streamflow data and model for the 2100 square mile James River watershed from the same region.

Ozone effects on sap flux in the Aspen FACE experiment. Responses of sap flow to ozone exposure have been derived from the Aspen FACE experiment near Rhinelander, 
Wisconsin $\left(45.6^{\circ} \mathrm{N}, 89.5^{\circ} \mathrm{W}\right.$; Uddling et al., 2008, 2009). The experiment consists of $12,30-\mathrm{m}$ diameter circular plots with three control plots and three replicate plots each receiving elevated $\mathrm{CO}_{2}$, elevated ozone, or both elevated $\mathrm{CO}_{2}$ and elevated ozone. Ozone exposure levels in the elevated ozone treatment of the Aspen FACE experiment (AOT60 $3.6 \mu \mathrm{l} \mathrm{l}^{-1} \mathrm{~h}$ over 90 days) were very similar to the 26-year mean ambient level in East Tennessee area (AOT60 $3.85 \mu \mathrm{ll}^{-1} \mathrm{~h}$ ) over the same approximate time interval. Ozone and $\mathrm{CO}_{2}$ treatments were distributed across three blocks. The experiment used 3 to 6-month-old seedlings planted at $1 \times 1 \mathrm{~m}^{2}$ spacing in July 1997 and fumigation treatments were initiated in spring 1998. Each plot is divided into three sub-plots with different tree community compositions. Here, we present data for mixed aspen-birch communities (Betula papyrifera Marsh. and Populus tremuloides Michx., clone 216) growing in control plots and elevated ozone plots in 2004, when steady state leaf area had been reached.

Sap flux of mixed aspen-birch stands was measured in 66 trees ( 33 in control +33 in elevated ozone) in 2004 and scaled to the stand level in this study as described by Uddling et al. $(2008,2009)$. Birch dominated over aspen with respect to both biomass and sap flux in ambient as well as elevated ozone stands (Kubiske et al., 2007; Uddling et al., 2008). Data were statistically tested for main effects of Ozone and Block and their interactions with Time (repeated measures) by analysis of variance using SAS PROC GLM, version 9.3.1 (SAS Institute, Cary, NC, USA).

\section{Results}

\section{Streamflow model structure and performance}

Exploratory analyses were used to define the most useful predictor variables from combinations of the three climate and three ozone predictors of streamflow over various time intervals chosen to represent the period of active forest canopy development and function. Table 2 summarizes results of model testing to determine the influence of adding terms describing the three measures of seasonal ozone exposure to the three variable models developed around the three indicators of climate. These comparisons were made over four time intervals over the growing season. Late season flow (August to October, indicated Flow $_{810}$ ) was the dependent variable and data in Table 2 compare results of model analysis for one of the smallest watersheds in a

Table 2 Summary of multiple partial correlation analysis of the importance of predictor time intervals in evaluating climate and ozone influences on late season streamflow for Walk Branch Watershed and New River Watershed. Models were developed around four Predictor Time Intervals to predict streamflow over the August-October time interval

\begin{tabular}{|c|c|c|c|c|c|}
\hline & & \multicolumn{4}{|c|}{ Monthly time interval for predictor variables ${ }^{1}$} \\
\hline & & 410 & 59 & 79 & 810 \\
\hline Model $(v)^{2}$ & & \multicolumn{4}{|c|}{ Model $R^{2}$} \\
\hline C only (3) & $R^{2}$ & 0.4 & 0.51 & 0.4 & 0.43 \\
\hline O only (3) & $R^{2}$ & 0.37 & 0.4 & 0.38 & 0.21 \\
\hline \multirow[t]{2}{*}{$\mathrm{C}+\mathrm{O}(6)^{3}$} & $R^{2}$ & 0.58 & 0.61 & 0.67 & 0.52 \\
\hline & & \multicolumn{4}{|c|}{ Partial $R^{2}$ attributable to ozone ${ }^{4}$} \\
\hline \multirow[t]{2}{*}{ Ozone contribution } & $\mathrm{P} R^{2}$ & 0.21 & 0.22 & 0.27 & 0.31 \\
\hline & $P \leq$ & 0.04 & 0.00003 & 0.007 & 0.002 \\
\hline \multirow[t]{2}{*}{ New River Watershed } & & \multicolumn{4}{|c|}{ Monthly time interval for predictor variables ${ }^{1}$} \\
\hline & & 410 & 59 & 79 & 810 \\
\hline \multicolumn{2}{|l|}{$\operatorname{Model}(v)^{2}$} & \multicolumn{4}{|c|}{ Model $R^{2}$} \\
\hline C only (3) & $R^{2}$ & 0.77 & 0.75 & 0.77 & 0.82 \\
\hline O only (3) & $R^{2}$ & 0.27 & 0.31 & 0.22 & 0.24 \\
\hline \multirow[t]{2}{*}{$\mathrm{C}+\mathrm{O}(6)^{2}$} & $R^{2}$ & 0.82 & 0.79 & 0.83 & 0.85 \\
\hline & & \multicolumn{4}{|c|}{ Partial $R^{2}$ attributable to ozone ${ }^{3}$} \\
\hline \multirow[t]{2}{*}{ Ozone contribution } & $P R^{2}$ & 0.04 & 0.04 & 0.03 & 0.04 \\
\hline & $P \leq$ & 0.07 & 0.24 & 0.13 & 0.31 \\
\hline
\end{tabular}

${ }^{1}$ Predictor time intervals are April-October (410), May-September (59), July-September (79), and August-October (810).

${ }^{2} v$ represents the number of predictor variables in each model.

${ }^{3}$ All C $+\mathrm{O}(6)$ models were significant at a $P<0.02$ level.

${ }^{4}$ Partial $R^{2}$ values were determined by multiple-partial correlation analysis. A partial F-test was used to evaluate the significance of the ozone contribution to each six variable $(3 \mathrm{C}+3 \mathrm{O})$ model. 
high ozone area, WBWS in Tennessee, with analyses from the largest watershed, NRWS, in a much lower ozone area in Southwest Virginia. Results indicated that models developed around the four time intervals were rather similar in strength, statistical significance, and provided generally similar attribution of the influences of ozone and climate across times within each watershed. The addition of ozone variables significantly improved performance of all models examined in Table 2. However, the ozone contribution for the simple six-variable models was stronger (19\% in average) and highly statistically significant for the higher ozone area in Tennessee. By contrast, overall models were stronger (higher $R^{2}$ ), but the estimated ozone signal was relatively weaker (4\%) and less significant for the NRWS.

Our primary analyses were of more complex models that included both interaction terms and multiple time intervals for predictor variables. Model $R^{2}$, significance, and estimates of the relative influences of ozone, climate, and ozone $\times$ climate interaction terms were all improved using Best Regression Analysis to identify the strongest sets of predictor variables. Ozone variables were frequently identified along with climate variables as significant contributors to variance in late season flow as the total number of predictor variables was increased from $n=3$ up to $n=11$, the maximum size included in these studies. Detection of effects on streamflow of climate, ozone, and ozone xclimate interactions and overall model fit to the streamflow data increased with increased numbers of predictor variables from $n=3$ up to $n=11$ (data not shown).

Comparative model structure and fit to the late season streamflow data for each of the six watersheds are shown in Table 3. These models typically contained at least seven predictor variables, and ozone terms were consistently represented among the most significant contributors to overall model performance. These empirical models fit the streamflow data very closely (Table 3 and Fig. 2a, b) and streamflow was strongly predicted by combined climate and ozone variables $\left(R^{2}=0.78-0.96\right)$. All models were highly statistically significant $(P<0.005)$. As noted in exploratory studies, the addition of ozone variables significantly improved the performance of all climate models. This result was consistent for watersheds from both higher and lower ends of the ozone exposure spectrum and across a 10 000-fold watershed size spectrum. Improvement in predictive capacity of flow models for both the 97 ha WBWS (Fig. 2a) in Tennessee and the 970000 ha New

Table 3 Model form and parameter values for six Appalachian Mountain Watersheds. All model terms that are not in bold, but included are significant at the $P \leq 0.05$ level

\begin{tabular}{|c|c|c|c|}
\hline Watershed & Model & $R_{\text {adj }}^{2}$ & $P$ \\
\hline $\begin{array}{l}\text { Walker Branch } \\
\text { Watershed (WBWS) }\end{array}$ & 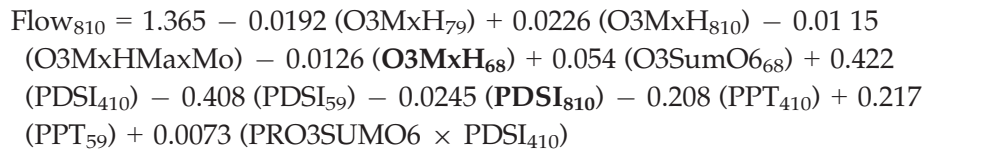 & 0.78 & $<0.0001$ \\
\hline Little River & 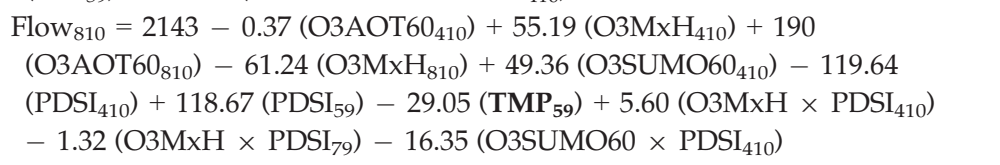 & 0.97 & $<0.0001$ \\
\hline Cataloochie Creek & 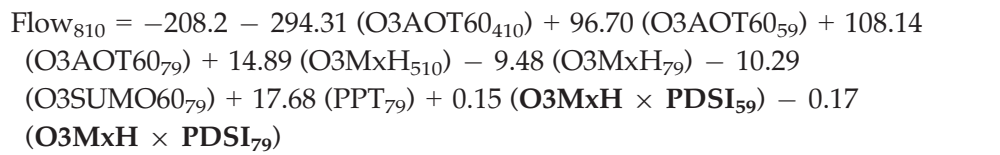 & 0.92 & $<0.0001$ \\
\hline New River & 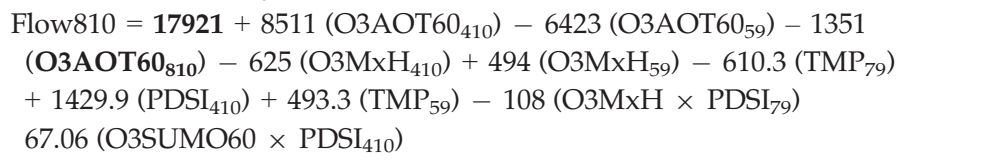 & 0.92 & $<0.0001$ \\
\hline James River (JRWS) & 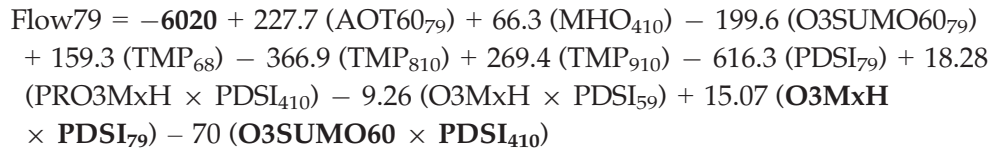 & 0.91 & $<0.0001$ \\
\hline $\begin{array}{l}\text { Fernow Experimental } \\
\text { Watershed }\end{array}$ & $\begin{array}{l}\text { Flow810 }=-\mathbf{0 . 6 5 9}+0.01\left(\mathrm{O}_{\mathrm{M}} \mathrm{H}_{810}\right)+0.287\left(\mathrm{O} 3 \mathrm{AOT} 60_{57}\right)-0.367 \\
\left(\mathrm{O}_{\mathrm{AOT}} 60_{59}\right)-0.0697\left(\mathrm{PPT}_{59}\right)-0.212\left(\mathrm{TMP}_{410}\right)+0.204\left(\mathrm{TMP}_{59}\right)-0.0162 \\
\left(\mathrm{WDF}_{410}\right)+0.0026\left(\mathrm{WDF}_{59}\right)+0.0005\left(\mathrm{O} 3 \mathrm{MxH} \times \mathrm{WDF}_{410}\right)-0.0019 \\
\left(\mathrm{O} 3 \mathrm{SUMO} \times \mathrm{WDF}_{410}\right)\end{array}$ & 0.92 & $<0.003$ \\
\hline
\end{tabular}

Unit of flow rate in this table is in cubic feet per second. 

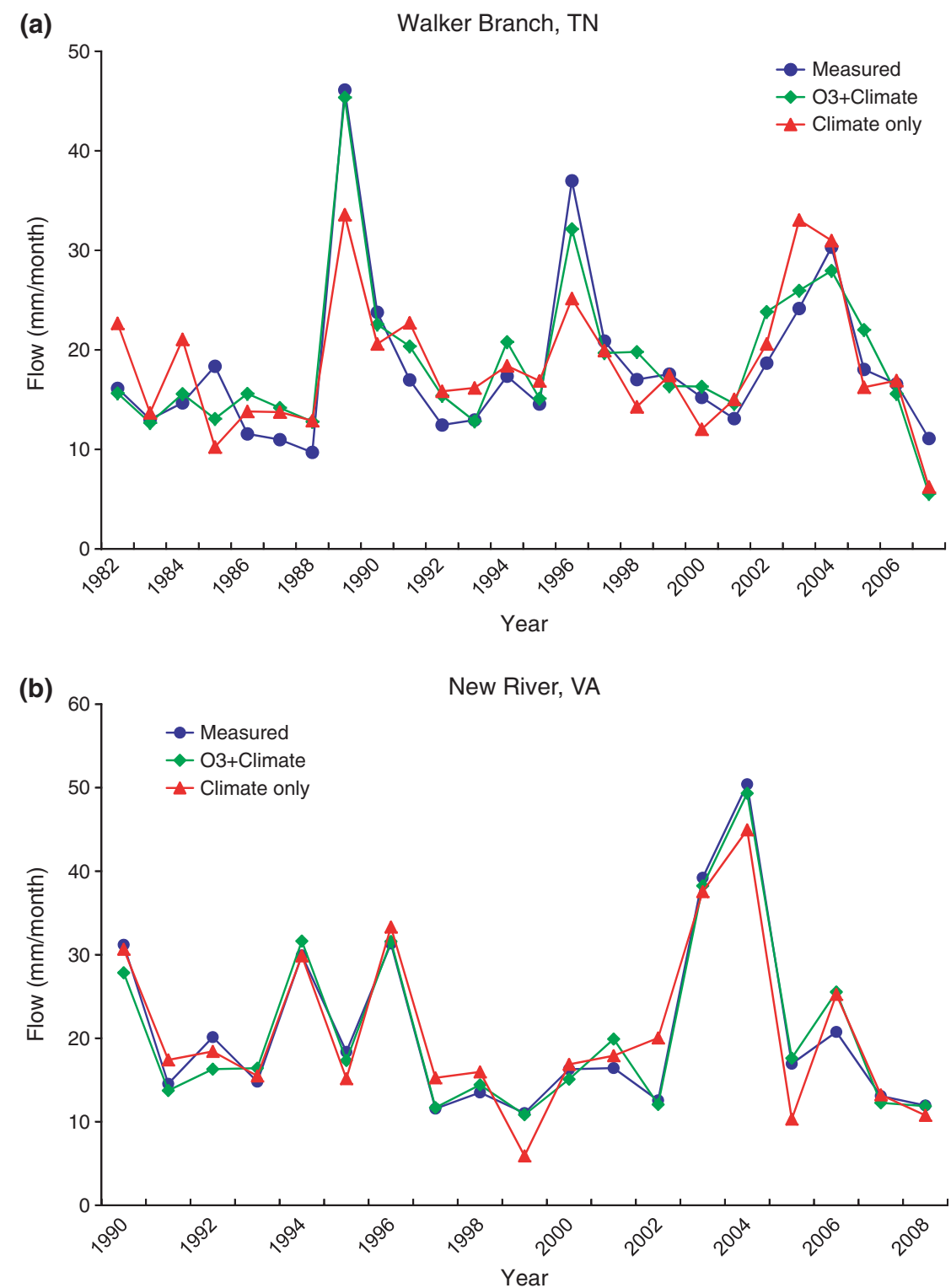

Fig. 2 Empirical models of annual variations in late season streamflow were significantly improved by including ozone and ozone $\times$ climate interactions. Comparisons include actual (solid circles) vs. predicted late season flow over 26 years with climate only (solid diamonds) and climate plus ozone (solid triangles) for both the of 94-ha Walker Branch Watershed in Tennessee (a) with climate only $R^{2}=0.51$ and climate plus ozone $R^{2}=0.78$ ) and the 970000 ha New River Watershed in Virginia (b) with climate only $R^{2}=0.75$; climate plus ozone $R^{2}=0.92$ ).

River (NR) watershed in Virginia (Fig. 2b) was substantial. The predictive $R^{2}$ for the best climate-only model improved from 0.51 to 0.78 for WBWS and from 0.78 to 0.96 for NRWS with the inclusion of ozone variables in the models.

Partitioning of model predictive capacity by MPC analysis (Kleinbaum et al., 1998) allowed us to isolate the unique contributions of each predictive variable class (predictive $R^{2}$ ) and to test the statistical significance of these contributions to overall model perfor- mance. The partitioned effects of ozone, climate, and ozone $\times$ climate interaction variables and their statistical significance as contributors to overall model fit to streamflow data are shown in Table 4. Climate and ozone effects on model fit were shown to be individually significant (typically $P<<0.02$ ) in all models. The ozone $\times$ climate interaction terms were also significant for all watersheds except Cataloochie Creek $(P<0.19)$. Ozone influences were highest (27\%) in the areas of the highest ozone exposure in Tennessee and lowest (7\%) 
Table 4 Contributions of ozone (O), climate (C), and ozone-climate interactions to explain late season flow of six forested watersheds in the southeastern United States

\begin{tabular}{|c|c|c|c|c|c|c|c|}
\hline \multirow[b]{2}{*}{ Watershed $^{2}$} & \multicolumn{7}{|c|}{ Partial $R^{2} \%$ for each model components ${ }^{1}$} \\
\hline & $\begin{array}{l}\text { Comp } \\
\text { mode }\end{array}$ & & Climate & $\mathrm{C}+\mathrm{C} \times \mathrm{O}$ & Ozone & $\mathrm{O}+\mathrm{C} \times \mathrm{O}$ & $\mathrm{C} \times \mathrm{O}$ \\
\hline Walker Branch, Oak Ridge, & $R^{2} \%$ & 88 & 23 & 52 & 27 & 27 & 7 \\
\hline TN, 98 ha, $n=26$ years & $\begin{array}{l}v^{3} \\
P<4\end{array}$ & $\begin{array}{l}11 \\
0.0001\end{array}$ & $\begin{array}{l}5 \\
0.0001\end{array}$ & $5+1$ & $\begin{array}{l}5 \\
0.0001\end{array}$ & $5+1$ & $\begin{array}{l}1 \\
0.04\end{array}$ \\
\hline Little River, GSMNP(W), TN, & $R^{2} \%$ & 99 & 1 & 53 & 18 & 34 & 15 \\
\hline 28000 ha, $n=19$ years & $\begin{array}{l}v \\
P<\end{array}$ & $\begin{array}{l}11 \\
0.0001\end{array}$ & $\begin{array}{l}3 \\
0.001\end{array}$ & $3+3$ & $\begin{array}{l}5 \\
0.02\end{array}$ & $5+3$ & $\begin{array}{l}3 \\
0.02\end{array}$ \\
\hline Cataloochie Creek, GSMNP (E), NC, & $R^{2} \%$ & 95 & 8 & 12 & 20 & 23 & 1 \\
\hline 12500 ha, $n=26$ years & $\begin{array}{l}v \\
P<\end{array}$ & $\begin{array}{l}9 \\
0.0001\end{array}$ & $\begin{array}{l}1 \\
0.0005\end{array}$ & $1+2$ & $\begin{array}{l}6 \\
0.0001\end{array}$ & $6+2$ & $\begin{array}{c}2 \\
\text { ns }(0.19)\end{array}$ \\
\hline $\begin{array}{l}\text { New River, Glen Lynn, VA, } \\
970000 \text { ha, } n=19 \text { years }\end{array}$ & $\begin{array}{l}R^{2} \% \\
v \\
P<\end{array}$ & $\begin{array}{l}96 \\
10\end{array}$ & $\begin{array}{l}17 \\
3 \\
0.0001\end{array}$ & $\begin{array}{r}61 \\
3+2\end{array}$ & $\begin{array}{l}12 \\
5 \\
0.0001\end{array}$ & $\begin{array}{r}15 \\
5+2\end{array}$ & $\begin{array}{l}7 \\
2 \\
0.005\end{array}$ \\
\hline $\begin{array}{l}\text { Parsons Branch Fernow, WV, } 38 \text { ha, } \\
n=18 \text { years }\end{array}$ & $\begin{array}{l}R^{2} \% \\
v \\
P<\end{array}$ & $\begin{array}{l}97 \\
10 \\
0.003\end{array}$ & $\begin{array}{l}20 \\
5 \\
0.0005\end{array}$ & $\begin{array}{r}61 \\
5+2\end{array}$ & $\begin{array}{l}7 \\
3 \\
0.02\end{array}$ & $\begin{array}{r}13 \\
3+2\end{array}$ & $\begin{array}{l}10 \\
2 \\
0.005\end{array}$ \\
\hline $\begin{array}{l}\text { James River, Buchanan, VA, } 550000 \text { ha, } \\
n=26 \text { years }\end{array}$ & $\begin{array}{l}R^{2} \% \\
v \\
P<\end{array}$ & $\begin{array}{l}95 \\
11 \\
0.0001\end{array}$ & $\begin{array}{l}9 \\
4 \\
0.0001\end{array}$ & $\begin{array}{r}57 \\
4+4\end{array}$ & $\begin{array}{l}8 \\
3 \\
0.0001\end{array}$ & $\begin{array}{r}12 \\
3+4\end{array}$ & $\begin{array}{l}7 \\
4 \\
0.0001\end{array}$ \\
\hline
\end{tabular}

${ }^{1}$ The percentage of total variance explained by each variable class was estimated by determining $R^{2}$ reduction realized by excluding those variables from the complete model.

${ }^{2}$ Monitoring location and watershed area are indicated. Little River and Cataloochie Creek drain the western and eastern slopes of the Great Smoky Mountains National Park (GSMNP).

${ }^{3} v$ is the number of predictor variables in each model.

${ }^{4} P$ is the probability of a greater $F$ for the effects of ozone variables in the full model.

Table 5 Partial correlation coefficients $(\mathrm{R})$ for ozone $(\mathrm{O})$ and ozone $(\mathrm{O}) \times$ climate $(\mathrm{C})$ interaction terms in watershed and tree growth models. Correlations were for measured late season stream flow or annual tree growth determined with climate held constant

\begin{tabular}{|c|c|c|}
\hline Watershed & Variable & $R$ \\
\hline Walker Branch & $\mathrm{C} \times \mathrm{O}$ & -0.62 \\
\hline Oak Ridge, TN & $\mathrm{O}+\mathrm{O} \times \mathrm{C}$ & -0.93 \\
\hline Little River & $\mathrm{C} \times \mathrm{O}$ & -0.62 \\
\hline GSMNP(W) Townsend, TN & $\mathrm{O}+\mathrm{O} \times \mathrm{C}$ & -0.99 \\
\hline Cataloochie Creek & $\mathrm{C} \times \mathrm{O}$ & -0.74 \\
\hline GSMNP (E), NC & $\mathrm{O}+\mathrm{O} \times \mathrm{C}$ & -0.68 \\
\hline New River & $\mathrm{C} \times \mathrm{O}$ & -0.84 \\
\hline Glen Lynn, VA & $\mathrm{O}+\mathrm{O} \times \mathrm{C}$ & -0.7 \\
\hline Fernow & $\mathrm{C} \times \mathrm{O}$ & -0.77 \\
\hline Parsons, WV & $\mathrm{O}+\mathrm{O} \times \mathrm{C}$ & -0.97 \\
\hline James River & $\mathrm{C} \times \mathrm{O}$ & -0.62 \\
\hline Buchanan, VA & $\mathrm{O}+\mathrm{O} \times \mathrm{C}$ & -0.92 \\
\hline Annual tree growth ${ }^{1}$ & $\mathrm{C} \times \mathrm{O} 3$ & -0.72 \\
\hline Blue Ridge Parkway, VA & $\mathrm{O}+\mathrm{O} \times \mathrm{C}$ & -0.93 \\
\hline
\end{tabular}

in West Virginia, the least industrialized area. Ozone effects identified by this process were, as expected, typically smaller than climate effects. An analysis of the variance indicated that the magnitude of ozone effects detected by the models were significantly $(P<0.05)$ related to average annual ozone levels from air quality monitoring across the region.

The addition of ozone $\times$ climate variables to the models significantly improved overall model fit to the streamflow data. Combined climate influences (Climate + ozone $\times$ climate terms) were improved more by the addition of interaction terms than were estimates of overall ozone (ozone + ozone $\times$ climate) influences (Table 4). In addition, the summed effects of ozone and ozone interaction terms, which sometimes combined positive and negative coefficients for different component time intervals (see Table 3), produced net negative effects on streamflow as evidenced by partial correlation coefficients of combined model terms summarized in Table 5. For these simple correlations, climate effects were held constant for each model system within which partial correlations were determined. 

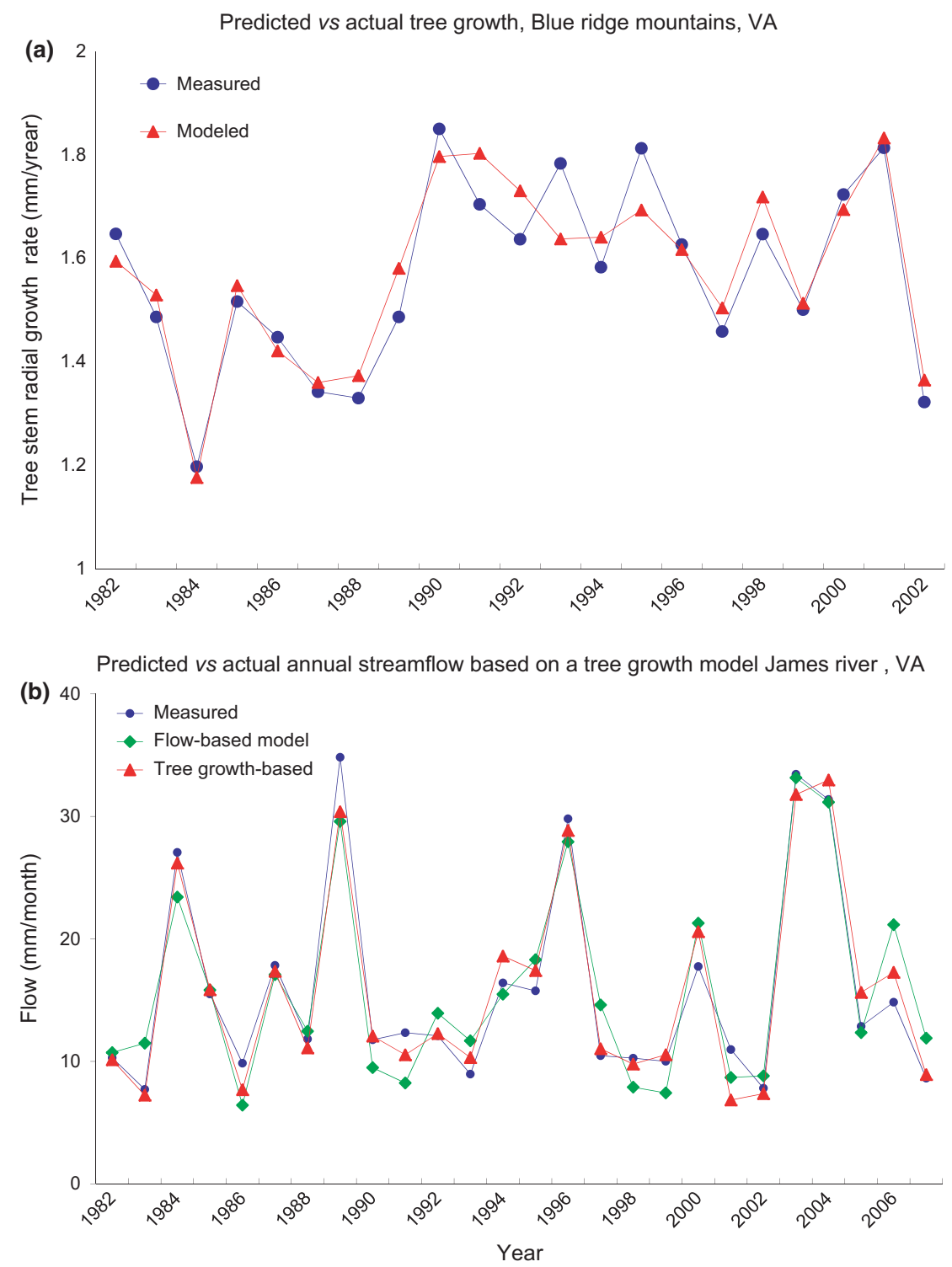

Fig. 3 Both annual variations in tree radial growth and in late season streamflow from the James River Watershed were linked to ozone and climate in similar ways. The same combinations of climate, ozone, and climate $\times$ ozone interactions selected to optimize prediction of annual tree growth of a five-species mean growth model for 175 trees shown in (a - triangles) with $R_{\text {adj }}^{2}=0.71$, also had high predictive capacity $\left(R_{\text {adj }}^{2}=0.78\right)$ in explaining annual variations in late season streamflow of the nearby James River Watershed $(b-$ triangles). Symbols are solid circles for observed tree growth (a) and streamflow rates (b). Flow predictions based on a flow-based model are also shown in

(b-diamonds).

\section{Interregional comparisons of model performance}

Tests of the predictive capability of a generalized seven-variable model developed for the WBWS $\left(R^{2}=0.74\right)$ across the larger study region indicated that the WBWS model had strong predictive capabilities at other watersheds within the region $\left(R^{2}=0.77-\right.$ 0.91 at other locations). This versatility was apparently limited to models that considered the influences of the relatively high ozone levels at the southern end of the study region as poor performance was achieved for models developed in the northern region and applied to the South. For example, the JRWS six-variable model $\left(R^{2}=0.89\right)$ that best predicted flow for this watershed did a relatively poor job of predicting WBWS flow $\left(R^{2}=0.41\right)$. Differential analysis of the influence of inter watershed differences in annual climate and ozone parameters on annual differences in flow 


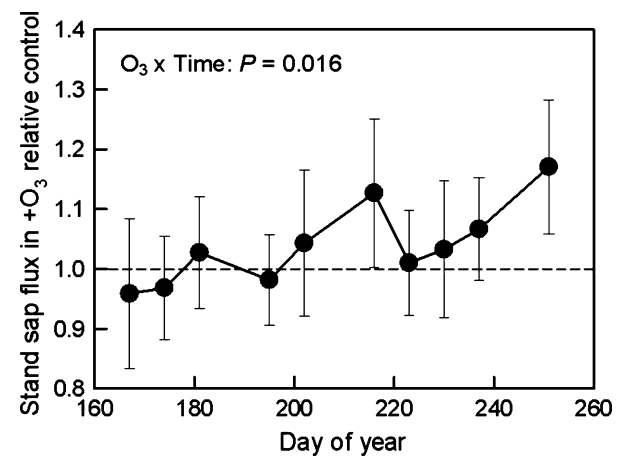

Fig. 4 The effect of elevated $\mathrm{O}_{3}\left(+\mathrm{O}_{3}\right)$ on stand sap flux (i.e. per unit ground area) of mixed aspen-birch communities in the Aspen FACE experiment at Rhinelander, WI, during the summer of 2004. The $\mathrm{O}_{3} \times$ time interaction was statistically significant $(P=0.016)$ although the main effect of elevated $\mathrm{O}_{3}$ was not $(P=0.53)$. Error bars represent standard error of the mean.

between WBWS and JRWS also supported the role of ozone in influencing differences in outflow patterns from these watersheds over time. Our analyses indicated that model input variables related to annual differences in ozone exposure and ozone $x$ climate interactions explained $46 \%$ of observed differences in annual flow between the James River and Walker Branch Watersheds over time whereas interregional differences in climate terms explained only $17 \%$ of the variability in those annual flow differences.

\section{Linkages between tree growth and watershed streamflow patterns}

To evaluate common responses to climate of mature trees and streamflow within the region, we tested a multi-species model based on annual radial tree growth as a predictor of annual streamflow patterns for the nearby James River Watershed (JRWS). The tree growth regression model, which was based on 20 years of annual growth data for 175 individual trees representing five species provided a good fit to the annual patterns in radial increment growth $\left(R^{2}=0.71\right.$ and Fig. 3a). The 11-variable tree growth model identified significant influences of PDSI (three terms), precipitation (two terms), $\mathrm{O} 3 \times$ PDSI (three terms), and Ozone alone (three terms) on annual tree growth patterns. Partial $\mathrm{F}$ analysis of the tree growth model provided estimates of the influence of climate alone $(50 \%), \mathrm{O}_{3}$ alone $(15 \%)$, and ozone $\times$ drought $\left(\mathrm{O}_{3} \times\right.$ PDSI; $\left.47 \%\right)$ on the variability $\left(R^{2}\right)$ in annual tree growth patterns. Both climate/ozone parameters and time intervals identified as significant by the tree growth model also provided strong prediction of late season flows of the nearby 525000 ha James River Watershed $\left(R^{2}=0.78\right.$ and Fig. 3b). MPC analysis indicated that detection sensitiv- ity of the streamflow model optimized to tree growth compared to the model optimized based on streamflow was reduced for estimated influences on streamflow of climate ( $12 \%$ vs. $50 \%)$, but comparable for influences of both $\mathrm{O}_{3}$ alone ( $8 \%$ vs. $8 \%$ ) and climate $\times \mathrm{O}_{3}(7 \%$ vs. $5 \%$ ). Thus, both tree growth and streamflow appeared to be influenced significantly by the same set of environmental input variables and both tree and watershed systems responded significantly and negatively to the influence of ozone and ozone $\times$ climate variables.

\section{Ozone effects on sap flux in the Aspen FACE experiment}

The Aspen FACE experiment (Uddling et al., 2008) provided a more specific experimental test of ozoneinduced changes in forest water use based on observations of stand tree water use in mixed aspen-birch communities of 5-8 $\mathrm{m}$ tall trees and steady state leaf area index in response to free-air delivery of ozone. There was no significant main effect of ozone on stand sap flux, with reduced leaf area index being compensated for by increased sap flux per unit leaf area (Uddling et al., 2008). However, there was a statistically significant ozone $\times$ time interaction $(P=0.016)$, with stand sap flux in elevated compared to ambient ozone increasing progressively during the summer (Fig. 4). Upper soil moisture (at $0-15 \mathrm{~cm}$ ) was decreased by ozone treatment during the first half of the summer (Uddling et al., 2008). This was most likely influenced by a combination of greater understory biomass, greater incident light reaching the understory under the ozone-affected overstory (Bandeff et al., 2006), and possibly greater transpiration rate per unit leaf area of the understory, as was measured in the overstory trees, in the ozone-treated plots. The lack of differences in overstory transpiration rate per unit of plot ground area during the early season (Fig. 4) suggests that ozone treatment effects on overstory trees did not contribute directly to this observed soil moisture reduction.

Similar ozone $x$ time interactions were found in aspen-birch stands exposed to elevated $\mathrm{CO}_{2}$ (i.e. elevated $\mathrm{CO}_{2}+$ ozone plots vs. elevated $\mathrm{CO}_{2}$ plots) as well as for another year with good seasonal data capture (2006), but was not observed in the pure aspen community type. Additional evidence of stomatal loss of sensitivity in the Aspen FACE experiment was provided by observations of ozone-induced reduction in stomatal responsiveness to short-term changes in $\mathrm{CO}_{2}$ concentration in birch leaves (Onandia et al., 2011).

\section{Discussion}

The biological and conceptual foundation for these analyses was previously measured changes in tree 
growth, canopy conductance, and water use in response to ozone (McLaughlin et al., 2007a,b). Evidence that ambient ozone levels in East Tennessee were high enough to increase water use by individual trees, to reduce soil moisture in the rooting zone of those trees, and to reduce water yield of three local watersheds led to our testing the hypothesis that ozone would reduce streamflow over much larger basins across the Appalachian region.

The empirical models we have developed for six watersheds over a five-state area indicated that climate and ozone acted both individually and interactively to reduce late season streamflow during the 18-26 years examined. These responses were consistent and statistically significant across watersheds representing a wide size range (38 ha to $970000 \mathrm{ha}$ ) and over a large geographical range (430 km latitude by $340 \mathrm{~km}$ longitude). Our regression modeling results indicate that ozone effects were consistently important in improving modeling accuracy beyond levels achieved by models based on physical climate only.

Ozone and climate were found to affect streamflow interactively in these experiments; however, we were able to provide conservative estimates of their individual effects by several analytical techniques. These included the use of Best Regression Analysis in variable selection during model development, Multiple Partial Correlation analysis in evaluating unique influences of each variable class (ozone, climate, and ozone climate interactions) as they contributed to overall model performance, and Partial Correlation Analysis to evaluate the significance of each of the three variable classes with climate held constant. These tests and an additional differential analysis of the relative importance of climate and ozone input variables in explaining year to year variation in streamflow between paired watersheds, strongly support the statistical significance of ozone effects on streamflow across our region. Estimates of streamflow effects attributed to ozone in the models were also significantly related to observed differences in ozone exposure levels across the region. In addition, the form of the ozone variables determined to be significant in the present watershed-scale studies, specifically the importance of peak hourly ozone concentrations per day, was often similar to that of variables identified in previous physiologically based studies of responses of individual trees (McLaughlin et al., 2007a,b).

Our dendroecological analyses of mature forest trees in the region showed that both tree growth and streamflow were negatively affected by the same set of climate and ozone predictor variables. Ozone can affect tree growth directly by inducing cumulative loss in production of photosynthate and indirectly by increasing water stress. Secondary effects on forest growth and forest hydrology may also occur through changes in root mass and soil moisture holding capacity associated soil organic matter content. Reduced allocation of photosynthate to roots and reduced root mass has frequently been observed in controlled experiments with ozone (Cooley \& Manning, 1987). There is very limited information on changes in root mass or soil carbon accumulation in the field. At a high pollution site (both $\mathrm{O}_{3}$ and $\mathrm{NO}_{\mathrm{X}}$ ) in a ponderosa pine stand in California, Grulke et al. (1998) attributed significantly lowered root mass primarily to combined pollutant stresses. In Aspen Face studies, Loya et al. (2003) found that a 50\% increase in ambient ozone reduced both the rate of formation of stable soil carbon and increased soil carbon turnover rates compared to the effects of a $50 \% \mathrm{CO}_{2}$ enrichment alone. Reduced root growth or losses in soil carbon coupled with increased transpiration would be expected to amplify soil-plant moisture stress and growth reduction of forest trees by ozone. However more information is needed on how these stresses are developed, and compensated for by assimilate allocation processes in forest ecosystems. In our studies increases in water use, water stress, and decreases in soil moisture and streamflow represent a common linkage to ozone exposure that these dendroecological analyses infer, but cannot prove. However, these linkages were supported by measurements of concurrent influences of ozone on sap flow, moisture stress patterns, and growth of tree stems, and soil moisture availability in our precedent studies at an intensive research site in Tennessee (McLaughlin et al., 2007a,b).

Our analyses of seasonal changes in canopy transpiration in response to elevated ozone at the Aspen FACE site further support the role of ozone in potentially increasing forest water use. The progressive increase in relative water use of aspen-birch communities under continuous ozone exposure (Fig. 4) provide stand level support for the hypothesis of dose-dependent, ozoneinduced predisposition of forests to drought through reduced stomatal control of water loss (Mansfield, 1998; Maier-Maercker, 1999). The present study also adds to previous findings from many sources that moderate elevation of ozone concentrations may impair stomatal control of water loss by causing less sensitive (or 'sluggish') stomatal responses. Although very high ozone levels and drought may certainly cause stomatal closure, we expect that under moderate ozone levels found under field conditions average $g_{\text {s }}$ levels are increased, however the array of expected responses also should include: (1) a stomatal closure response to increased intercellular $\mathrm{CO}_{2}$ concentrations when photosynthesis is reduced, and (2) impairment of stomatal responsiveness to environmental variables (Uddling 
et al., 2009). Although (1) may dominate in plants with ample water supply, it is possible that (2) may be more important in water-limited environments where stomatal regulation of water losses during times of low soil water availability are critical.

Results from the Aspen FACE site are compatible with our previous findings with mature trees in several ways, including negative effects of ozone on tree growth, a progressive seasonal effect of ozone on canopy water use that was most apparent late in the growing season, and a reduction in soil moisture in the upper soil profile (McLaughlin et al., 2007a,b; Uddling et al., 2008). Because annual scale ozone effects on streamflow can come only through its effects on the rate and/or duration of transpiration during the growing season, we infer that increased plant water use, reduced soil moisture, decreased tree growth, and decreased streamflow are linked components in ozone $\times$ climate interactions contributing to the apparent changes in forest water use efficiency observed in our study.

The results of this study support our hypothesis that ambient ozone levels can interact with climate stress to increase water use by the forests in the study region. Our findings on the late season streamflow and ozone relationships and a wide range of previous field studies with forest trees using diverse experimental systems (Maier-Maercker, 1999; Grulke et al., 2002, 2004, 2007a, b; McLaughlin et al., 2007a,b; Uddling et al., 2008, 2009) challenge that the limits of the generalization derived from controlled studies that ozone typically reduces $g_{\mathrm{s}}$ (Wittig et al., 2007). Our results suggest that longer term exposure of trees to moderate ozone concentrations cause progressive loss of stomatal control over transpiration that may increase $g_{\mathrm{s}}$ and forest water use in ways not predicted by short-term exposures of smaller well-watered plants under higher ozone levels.

Ozone-induced increases in stomatal conductance have other important implications in addition to increased water use, including notably, increased fluxes of ozone to metabolically active tissues within leaves. In a grassland species, Hayes et al. (2012) measured a $30-40 \%$ increase in $\mathrm{O}_{3}$ flux due to ozone-induced increases in $g_{\mathrm{s}}$. While most efforts to understand the potential of $\mathrm{O}_{3}$ to affect $g_{\mathrm{s}}$ have understandably been directed to the dynamics of daytime fluxes, it is important to note that significant leaf gas exchange may also occur at night. Night-time transpiration is not uncommon in woody species (Dawson et al., 2007) and it can also be significantly affected by ozone exposure. Ozone induced increases in nocturnal transpiration have included reports of both delayed stomatal closure (sluggishness) and/or sustained stimulation of nighttime transpiration following controlled ozone exposure of tree saplings (Keller \& Hasler, 1984; Skarby et al., 1987; Grulke et al., 2007; Paoletti \& Grulke, 2010). For oak seedlings, nocturnal transpiration was $30 \%$ of daytime values and was stimulated $60-80 \%$ by chronic ozone exposure (Grulke et al., 2007). Grulke et al. (2004) found night-time $g_{\mathrm{s}}$ of mature for ponderosa pine trees in the field to range from $10 \%$ to $20 \%$ of daytime values and to increase across an increasing east-west $\mathrm{NO}_{\mathrm{X}}$ gradient. In controlled studies with birch cuttings, night-time $g_{\mathrm{s}}$ values as high as $50 \%$ of maximum daytime values, which in this case were not affected by $\mathrm{O}_{3}$ exposure, have been reported to significantly influence both ozone uptake and effects (Mattyssek et al., 1995). Thus the uptake and effects of future gaseous pollutant levels may be underestimated for both forests (Grulke et al., 2002, 2004, 2007) and grassland systems (Hayes et al., 2012) because existing models do not adequately consider natural or altered diurnal patterns and/or stomatal conductance responses to ambient ozone and other pollutant exposure levels.

Our study indicated that the detected increase in water use by mature forests exposed to ambient ozone levels is a generalizable property of forest ecosystems in this study region and not a response of a few species under a narrow range of conditions. Both the direction and magnitude of streamflow responses in our region suggest that ambient levels of ozone will episodically increase the frequency and duration of low flow periods. These measured effects on water use by forests are opposite to those predicted based on assumed stomatal closure induced by $\mathrm{O}_{3}$ and $\mathrm{CO}_{2}$ in most current forest ecosystem models (Felzer, 2004; Hanson et al., 2005; Gedney, 2006; Alley, 2007; Sitch et al., 2007; Ren et al., 2011). We believe that the distinction between responses of mature forests to moderate ozone concentrations in water-limited environments, as measured in the often present study, and those (i.e. reduced $g_{\mathrm{s}}$ ) typically observed with high ozone levels in wellwatered controlled experiments is important and should be considered in predicting current and future ozone effects on forest ecosystems.

Increasing evapotranspiration and reduced streamflow under regionally elevated ozone exposure have important implications for both the health and function of forest ecosystems. Results for our study region suggest that the frequency and severity of projected drought will likely be amplified by ozone-induced increases in water loss by forest transpiration. Existing ecosystem and global climate models that do not account for these climate-ozone interactions may be biased toward underestimation of ozone uptake, drought stress, and growth limitations of terrestrial ecosystems under projected future atmospheric conditions. Further evaluation of the feedbacks between current and future tropospheric 
ozone levels, a warming climate, and forest evapotranspiration in other regions is warranted.

\section{Acknowledgements}

This research was initiated in 1990 with support from the USDA Forest Service and the National Park Service. Intervening support for analysis by G. Sun was provided through the US Forest Service Eastern Forest Environmental Threat Assessment Center and for analyses by S. McLaughlin as a private initiative since 2006. Oak Ridge National Laboratory is managed by UTBattelle, LLC, for the U. S. Department of Energy under contract DE-AC05-00OR22725. Support for J. Porter was provided by NSF GRANT 0621014. The authors wish to thank Jim Renfro, Air Quality Specialist, National Park Service, Smoky Mountains National Park; Billy Pugh, Air Quality Specialist with the Tennessee Division of Environmental Quality, Nashville, Tennessee, and Carolyn Stevens, Data Analyst, Virginia Division of Environmental Quality, Richmond Virginia for their valuable assistance in acquiring historical ozone data for study sites in Tennessee and Virginia.

\section{References}

Alley R et al. (2007) Climate Change 2007: The Physical Science Basis. Summary for Policy Makers. International Panel on Climate Change. Fourth Assessment Report, IPCC Secretariat, Geneva, Switzerland.

Ball JT, Woodrow IE, Berry JA (1987) A model predicting stomatal conductance and its contribution to the control of photosynthesis under different environmental conditions. In: Progresses in Photosynthesis Research, Vol. IV (ed. Biggins I), pp. 221-224. Martinus Nijhoff Publishers, the Netherlands.

Bandeff JM, Pregitzer KS, Loya WM, Holmes WE, Zak DR (2006) Overstory community composition and elevated atmospheric $\mathrm{CO}_{2}$ and $\mathrm{O}_{3}$ modify understory biomass production and nitrogen acquisition. Plant and Soil, 282, 251-259.

Barnes JD, Brown KA (1990) The influence of ozone and acid mist on the amount and wettability of the surface waxes in Norway spruce (Picea abies [L.] Karst.). New Phytologist, 114, 531-535.

Bonan GB (2008) Forests and climate change: forcings, feedbacks, and the climate benefits of forests. Science, 320, 1444-1449.

Cooley DR, Manning WJ (1987) The impact of ozone on assimilate partitioning in plants: a review. Environmental Pollution, 47, 95-113.

Dawson TE, Burgess SSO, Tu KP et al. (2007) Nighttime transpiration in woody plants from contrasting ecosystems. Tree Physiology, 27, 561-575.

Felzer B et al. (2004) Effects of ozone on net primary production and carbon sequestration in the conterminous United States using a biogeochemistry model. Tellus, 56B, 230-248.

Fowler D (1999) The global exposure of forests to air pollution. In: Forest Growth Responses to the Pollution Climate of the 21st Century (eds Sheppard LJ, Cape JN), pp. 5-32. Kluwer Academic Publ., Lancaster.

Friedlingstein P (2006) Climate-carbon cycle feedback analysis: results from C4MIP model inter-comparison. American Meteorology Society, 19, 3337-3353.

Gedney N et al. (2006) Detection of a direct carbon dioxide effect in continental river runoff records. Nature, 439, 835-838.

Grulke NE, Andersen CP, Fenn ME, Miller PR (1998) Ozone exposure and nitrogen deposition lowers root biomass of ponderosa pine in the San Bernardino Mountains, California. Environmental Pollution, 103, 63-73.

Grulke NE, Preisler HK, Fan CC, Retzlaff WA (2002) A statistical approach to estimate $\mathrm{O}_{3}$ uptake of ponderosa pine in a mediterranean climate. Environmental Pollution, 107, 163-175

Grulke NE, Alonso R, Nguyen T, Cascio C, Dobrowolski W (2004) Stomata open at night: implications for pollutant uptake in ponderosa pine. Tree Physiology, 24, 1001-1010

Grulke NE, Paoletti E, Heath RL (2007) Chronic vs. short term acute $\mathrm{O}_{3}$ exposure effects on nocturnal transpiration in two Californian oaks. The Scientific World I, 7, 134-140.

Grulke NE, Neufeld HS, Davison AW, Roberts M, Chappelka AH (2007a) Stomatal behaviour of ozone-sensitive and -insensitive coneflowers (Rudbeckia laciniata var. digitata) in Great Smoky Mountains National Park. New Phytologist, 173, 100-109.

Grulke NE, Paoletti E, Heath RA (2007b) Comparison of calculated and direct measurements of foliar $\mathrm{O}_{3}$ uptake in crop and native tree species. Environmental Pollution, 146, 640-647.

Hanson PJ, Wullschleger SD, Norby RJ, Tschaplinski TJ, Gunderson CA (2005) Importance of changing $\mathrm{CO}_{2}$, temperature, precipitation, and ozone on carbon and water cycles of an upland-oak forest: incorporating experimental results into model simulations. Global Change Biology, 11, 1402-1423.

Hayes F, Wagg S, Mills G, Wilkinson S, Davies W (2012) Ozone effects in a drier climate: implications for stomatal fluxes of reduced stomatal sensitivity to soil drying in a typical grassland species. Global Change Biology, 18, 948-959.

Jung M et al. (2010) Recent deceleration of global land evapotranspiration due to moisture supply limitation. Nature, 467, 951-954

Keller T, Hasler R (1984) The influence of a fall fumigation with ozone on the stomatal behavior of spruce and fir. Oecologia, 64, 284-286.

Kleinbaum DG, Kupper LL, Muller KE, Nizam A (1998) Applied regression analysis and multivariable methods. (3rd edn). Duxbury, Pacific Grove, CA, pp. 139-216.

Kubiske ME, Quinn VS, Marquardt PE, Karnosky DF (2007) Effects of elevated atmospheric $\mathrm{CO}_{2}$ and/or $\mathrm{O}_{3}$ on intra-and interspecific competitive ability of Aspen Plant Biology, 9, 342-355.

Lening R (1995) A critical appraisal of a combined stomatal-photosynthesis model for C3 plants. Plant, Cell and Environment, 18, 339e355.

Loya WM, Pregitzer KS, Karberg NJ, King JS, Glardina CP (2003) Reduction of soil carbon formation by tropospheric ozone under increased carbon dioxide levels. Nature, 425, 705-706.

Maier-Maercker U (1999) Predisposition of trees to drought stress by ozone. Tree Physiology, 19, 71-78.

Maier-Maercker U, Koch W (1991) Experiments on the control capacity of stomata of Picea abies (L.) Karst. after fumigation with ozone and in environmentally damaged material. Plant, Cell and Environment, 14, 175-184.

Mansfield T (1998) Stomata and plant water relations: does air pollution create problems? Environmental Pollution, 101, 1-11.

Mattssyek R, Günthardt-Goerg MS, Maurer S, Keller T (1995) Nighttime exposure to ozone reduces whole-plant production in Betula pendula. Tree Physiology, 15, 159 165

McAinsh MR, Evans NH, Montgomery LT, North KA (2002) Calcium signalling in stomatal responses to pollutants. New Phytologist, 153, 441-447.

McLaughlin SB, Downing DJ (1995) Interactive effects of ozone and climate measured on mature forest trees. Nature, 374, 252-257.

McLaughlin SB, Percy K (1999) Forest health in North America: some perspectives on actual and potential roles of climate and air pollution. Water, Air, and Soil Pollution, 116, 151-197.

McLaughlin SB, Nosal M, Wullschleger SD, Sun G (2007a) Interactive Effects of ozone and climate on tree growth and water use in a southern Appalachian forest in the USA. New Phytologist, 174, 109-124.

McLaughlin SB, Wullschleger SD, Sun G, Nosal M (2007b) Interactive effects of ozone and climate on water use, soil moisture content, and streamflow in a Southern Appalachian Forests in the USA. New Phytologist, 174, 125-136.

Mills G, Hayes F, Wilkinson S, Davies WJ (2009) Chronic exposure to increasing background ozone impairs stomatal functioning in grassland species. Global Change Biology, 15, 1522-1533.

Morales P, Sykes MT, Prenticew IC et al. (2005) Comparing and evaluating processbased ecosystem model predictions of carbon and water fluxes in major European forest biomes. Global Change Biology, 11, 2211-2233.

Noormets A, Kull O, Sober A, Kubiske ME, Karnosky DF (2010) Elevated CO response of photosynthesis depends on ozone concentration in aspen. Environmen tal Pollution, 158, 992-999.

Ollinger SV, Aber JD, Reich PB, Freuder RA (2002) Interactive effects of nitrogen deposition, tropospheric ozone, elevated $\mathrm{CO}_{2}$, and land use history on the carbon dynamics of northern hardwood forests. Global Change Biology, 8, 545-562.

Onandia BG, Olsson AK, Barth S, King JS, Uddling J (2011) Exposure to moderate concentrations of tropospheric ozone impairs tree stomatal response to carbon dioxide. Environmental Pollution, 159, 2350-2354.

Paoletti E, Grulke NE (2010) Ozone exposure and stomatal sluggishness in different plant physiognomic classes. Environmental Pollution, 158, 2664-2671.

Pearson M, Mansfield TA (1993) Interacting effects of ozone and water stress on the stomatal resistance of beech (Fagus sylvatica L.). New Phytologist, 123, 351358

Pitman AJ (2003) The evolution of, and revolution in, land surface schemes designed for climate models. International Journal of Climatology, 23, 479-510. 
Prentice C, Bondeau A, Cramer W et al. (2007) Dynamic global vegetation modelling: quantifying terrestrial ecosystem responses to large-scale environmental change. In: Terrestrial Ecosystems in a Changing World (eds Canadell JG, Pataki D, Pitelka LF), pp. 175-192. Springer, Berlin, Germany.

Reiling K, Davison AW (1995) Effects of ozone on stomatal conductance and photosynthesis in populations of Plantago major L. New Phytologist, 129, 587-594.

Ren W, Tian H, Tao B et al. (2011) Impacts of tropospheric ozone and climate change on net primary productivity and net carbon exchange of China's forest ecosystems assessed with the dynamic land ecosystem model (DLEM). Global Ecology and Biogeogrpahy, 20, 391-406.

Ryan MG, Harmon ME, Birdsey RA et al. (2010) A synthesis of the science on forests and carbon for U.S. forests. Ecological Society of America, Issues In Ecology, $13,1-16$.

Samuelson L, Kelly JM (2001) Scaling ozone effects from seedlings to forest trees Tansley review 21. New Phytologist, 149, 21-41.

Skarby L, Troeng E, Bostrom CA (1987) Ozone uptake and effects on tran-spiration, net photosynthesis, and dark respiration in scots pine. Forest Science, 33, 801-808.

Schulze E-D, Robichaux RH, Grace J, Rundel PW, Ehlerinnger JR (1987) Plant water balance. BioScience, 37, 30-37.

Sellers PJ, Bounoua L, Collatz GJ et al. (1996) Comparison of radiative and physiological effects of doubled atmospheric $\mathrm{CO}_{2}$ on climate. Science, 271, 1402-1406.

Sitch S, Cox PM, Collins WJ, Huntingford C (2007) Indirect radiative forcing of climate change through ozone effects on the land-carbon sink. Nature, 448, 791-794.

Skarby L, Ro-Poulsen H, Wellburn FAM, Sheppard LJ (1998) Impacts of ozone on forests: a European perspective. New Phytologist., 139, 109-122

Smakhtin VU (2001) Low flow hydrology: a review. Journal of Hydrology, 240, 147-186.

Sun G, Alstad K, Chen J et al. (2011a) A general predictive model for estimating monthly ecosystem evapotranspiration. Ecohydrology, 4, 245-255.

Sun G, Caldwell P, Noormets A et al. (2011b) Upscaling key ecosystem functions across the conterminous United States by a water-centric ecosystem model. Journal of Geophysical Research, 116, G00J05.

The Royal Society (2008) Ground-Level Ozone in the 21st Century: Future Trends, Impacts and Policy Implications. The Royal Society, London, 132 p. Science Policy Report, 15/08.

Uddling J, Teclaw RM, Kubiske ME, Pregitzer KS (2008) Sap flux in pure aspen and mixed aspen-birch forests exposed to elevated concentrations of carbon dioxide and ozone. Tree Physiology, 28, 1231-1243.

Uddling J, Teclaw RM, Pregitzer KS, Ellsworth DS (2009) Leaf and canopy conductance in aspen and aspen-birch forests under free-air enrichment of carbon dioxide and ozone. Tree Physiology, 29, 1367-1380.

Vingarzan R (2004) A review of surface ozone background levels and trends Atmospheric Environment, 38, 3431-3442.
Wigley TMI, Briffa KR, Jones PD (1984) Predicting plant productivity and water resources. Nature, 312, 102-103.

Wilkinson S, Davies WJ (2009) Ozone suppresses soil drying- and abscisic acid (ABA)-induced stomatal closure via an ethylene-dependent mechanism. Plant Cell and Environment, 32, 949-959.

Wilkinson S, Davies WJ (2010) Drought, ozone, ABA and ethylene: new insights from cell to plant to community. Plant Cell and Environment, 33, 510-525.

Wittig VE, Ainsworth EA, Long SP (2007) To what extent do current and projected increases in surface ozone affect photosynthesis and stomatal conductance of trees? A meta-analytic review of the last three decades of experiments. Plant, Cell and Environment, 30, 1150-1162.

Zhao M, Running SW (2010) Drought-induced reduction in global terrestrial net primary production from 2000 through 2009. Science, 5994, 940-943.

\section{Supporting Information}

Additional Supporting Information may be found in the online version of this article:

Data S1. An overview of methods and analytical strategy.

Figure S1. Historical ozone trends for AOT6059 across the study region.

Figure S2. Historical ozone trends for hourly maximum per day across the study region.

Table S1. Mean environmental data for the six watersheds.

Table S2. Estimates of ozone effects on flow of six Appalachian watersheds based on model estimates of contributions of ozone and climate to variance in annual flow.

Please note: Wiley-Blackwell are not responsible for the content or functionality of any supporting materials supplied by the authors. Any queries (other than missing material) should be directed to the corresponding author for the article. 


\section{Supplementary Information}

\section{An Overview of Methods and Analytical Strategy}

We have included this section to expand upon both conceptual and statistical details included in the documentation of primary methods in the main text. Because this was an exploratory study we examined a diverse range of potentially useful predictor environmental variables to be used in defining factors that most strongly influenced late season streamflow. For this study late season streamflow was defined as the average monthly flow over the interval August through October. Other flow intervals were also examined, including the interval April through October, September and October, and the minimum weekly flow within the August - October interval. Similar results were found for most of these intevals. We focused on August through October as it corresponded to a period of fully mature foliage, late in the growing season, and an interval for which chonic effects from 3-4 months of previous exposure of foliage to ozone would be expected be more likely. This was based in part on our previously published studies of ozone effects on growth and water use by individual trees in Tennessee in which effects on seasonal growth patterns were more apparent late in the growing season (McLaughlin et al., 2007).

As discussed in the text, we chose as predictor environmental variables traditional measures of physical climate, temperature, PDSI, and rainfall, that were available at relevant locations across our entire study region. Ozone data were acquired from 4 regional and 1 local monitoring stations to represent the regional air quality within the airsheds in which our 6 watersheds were located. The ozone data were characterized by metrics that decades of air pollution research tell us can be important in defining potentially phytotoxic levels of exposure to ozone. They included averages of both hourly peak concentrations each day, and accumulated exposure doses at and above $60 \mathrm{nl} / \mathrm{l}$, a frequently used threshhold for phytotoxicity (Fowler, 1999),. For all environmental data we used monthly averages over intervals that would most logically influence both biological and physical limitations on water flow through hydrologic pathways from the atmosphere, through processing forests to streams. These were segmented into 2 to 7 month, sometimes overlapping, averaging intervals to capture phenotypic variations expected and found across the $430 \mathrm{~km}$ North -South latitudinal gradient encompassing the 6 study sites.

The combination of 6 primary indicators (3 physical climate and 3 ozone variables) and four product terms to capture drought (PDSI)* Ozone interactions (see SI 2.0), gave us 34 total possible environmental predictors to consider - an excessive number to test en mass with only 26 years of streamflow data. We approached this task by restricting initial analyses to predictor subsets that were determined to most closely correlate with streamflow and by initially 
analyzing ozone and climate data subsets separately to determine which sets of variables were most effective as streamflow predictors. In this process the ultimate model building was done using Best Regression Analysis (Kleinbaum et al., 1998) to identify the best combinations of predictor variables from subsets of 14 or fewer candidates. These were selected from equal numbers of candidate ozone and climate predictor variables to assure equal chances of ozone and climate variables appearing in the final model.

We have conducted numerous tests to validate the statistical validity and predictive capacity of the streamflow models we have developed in this process. The validity of the ozone signal was verified both by determining that models based solely on climate were consistently and significantly improved by the addition of ozone predictor terms and by measuring the effects of removal of ozone variables from the best models developed with both climate and ozone predictors. The Multiple-Partial Correlation Analysis by which we made separate estimates of ozone and climate signals in complete models, which had 7-11 predictor variables, was also used to estimate the influence of model size and complexity on the relative magnitude of estimates of both ozone and climate influences. For both the Walker Branch Watershed (WBWS) and the New River Watershed (NRWS), estimates of both ozone and ozone climate interactions as well as estimates of climate plus climate*ozone interactions steadily improved and stayed in the same relative ratio to eachother as overall model $\mathrm{R} 2$ improved at all levels from $\mathrm{N}=3$ to $\mathrm{N}=11$. For WBWS, estimates of the influences of $\mathrm{O}+\mathrm{O} * \mathrm{C}$ averaged $27 \%$ and increased from $25 \%$ at $\mathrm{N}=3$ to $27 \%$ at $\mathrm{N}=11$. Influences of $\mathrm{C}+\mathrm{C}^{*} \mathrm{O}$ averaged $50 \%$ of $\mathrm{R} 2$ and increased from $42 \%$ at $\mathrm{N}=3$ to $62 \%$ at $\mathrm{N}=11$. Similarly, for NRWS $\mathrm{O}+\mathrm{O}^{*} \mathrm{C}$ influences ranged from $11 \%$ at $\mathrm{N}=3$ to $15 \%$ at $\mathrm{N}=10$, while $\mathrm{C}+\mathrm{C}^{*} \mathrm{O}$ was more stable, ranging from $64 \%$ at $\mathrm{N}=3$ to $62 \%$ at $\mathrm{N}=10$. Thus estimates of contributions of climate and ozone components in the models were rather consistent across models at increasing levels of complexity.

The possibility of overfitting models was also explored by determining that models developed from subsets of the same data were consistent in form and fit to the data. In addition the consistencies in form and fit to watershed flow data across watersheds also support the strength and validity of models developed by these methods of variable definition and selection. Variable subsets identified as important at one watershed worked well at other watersheds. A separate test to estimate relative contributions of annual differences in patterns of ozone and climate to annual differences in flow between the Walker Branch and New River Watersheds identified annual differences in ozone exposure as being relatively more important than differences in climatic factors in contributing to these annual flow differences. 
More detailed descriptions of methodological procedures in these studies can be found in the following sections: Watershed Characteristics and Data Sources (SI 1.0); Intraregional Comparisons of Watershed Flow Characteristics and Environmental Data_(SI 2.0); Historical Ozone Exposures Across the Study Region (SI 3.0); and Estimating the Relative Magnitude of Ozone Effects on Streamflow (SI 4.0).

\section{SI1.0 Watershed Characteristics and Data}

The locations of all watersheds examined in these studies are noted in Figure 1 of the main text. The direction of flow is indicated by area proportional triangles with the downstream apex located at the position of the monitoring stations. The two largest watersheds examined the Upper James ( 525,000 ha) and the New River $(970,000$ ha) were estimated by land cover maps to be at least $75 \%$ in mature second growth forests. The remaining four watersheds were estimated at $>95 \%$ forest cover. All watersheds were typically forested with mixed deciduous forests typically dominated by oaks, hickories, and yellow poplar.

a. Walker Branch Watershed (WBWS), TN - Analysis interval: 26 yrs, 1982-2007. Located at Oak Ridge, Tennessee, this research watershed is comprised of a total of 98 ha of forested hills at $\mathbf{2 0 0 - 3 0 0 ~ m ~ i n ~ e l e v a t i o n . ~ T h e ~ w a t e r s h e d ~ h a s ~ b e e n ~ m a i n t a i n e d ~ a s ~ a ~ l o n g ~}$ term research facility by Oak Ridge National Laboratory (ORNL) for the Department of Energy and its predecessor agencies since 1969. Estimated forest cover is $>99 \%$. Flow, temperature, and precipitation data for 1982-2007 were acquired from the Walker Branch Watershed website: (http://walkerbranch.ornl.gov). Regional Palmer Drought Severity Index (PDSI) data were derived from National Atmospheric and Oceanic Administration (NOAA) for Tennessee Climate Division 6. Ozone data were provided for the Mascot, TN station located approximately $30 \mathrm{~km}$ East of from Oak Ridge. This station is maintained by the State of Tennessee, Division of Air Quality.

b. Little River (LR), TN - Analysis interval: 19 yrs, 1989-2007. The Little River, monitored at Townsend Tennessee, comprises over 28,000 ha (106 square miles) of forest lands located along the western slopes of the Great Smoky Mountains National Park. This watershed ranges in elevation from 200 to $2300 \mathrm{~m}$ and is fully forested. Temperature, precipitation and ozone data for 1982-2007 were provided by Jim Renfro, Air Quality Specialist with the National Park Service from a monitoring station maintained at Look Rock TN. The Look Rock Station is located at $750 \mathrm{~m}$ elevation at ridge crest approximately $30 \mathrm{~km}$ east of the Townsend, stream gauging station. Regional Palmer 
Drought Severity Index (PDSI) data were derived from NOAA for Tennessee Climate Division 6. Streamflow data were obtained from the US Geological Survey (USGS).

c. Cataloochee Creek (CC), NC-Analysis interval: 26 yrs, 1982-2007. The USGS gauging streamflow gauging station for this watershed is at latitude $35^{\circ} 40^{\prime} 02^{\prime \prime}$ and longitude $83^{\circ} 04^{\prime} 22^{\prime \prime}$. The basin drains $127 \mathrm{~km}^{2}$ of steep, mountainous fully forested terrain that ranges in elevation from $749 \mathrm{~m}$ at the gage to $1,876 \mathrm{~m}$. The main channel is perennial with a mean monthly discharge varying from $1.5 \mathrm{~m}^{3} / \mathrm{s}$ during low flow in September and October to $5.7 \mathrm{~m}^{3} / \mathrm{s}$ in March when spring rains combine with snowmelt. Average annual runoff from the basin was $78 \mathrm{~cm}$ from 1934 through 1995 (U.S. Geological Survey, Water Resources Data, North Carolina). Climate of the area is characterized by abundant precipitation and moderate temperatures. Mean monthly air temperatures range from $4^{\circ} \mathrm{C}$ in December to $23^{\circ} \mathrm{C}$ in July at an elevation of $445 \mathrm{~m}$ and $0^{\circ} \mathrm{C}$ in March to $16^{\circ} \mathrm{C}$ in July at an elevation of $1,920 \mathrm{~m}$.

d. New River (NR), VA - Analysis interval: 19 yrs, 1990-2008. The New River Watershed drains approximately 970,000 hectares ( 3768 Square miles) of predominantly forested (>80\% forest) mountain lands in Southwestern Virginia. The stream gauge is maintained by the US Geological Survey at Glen Lynn, VA near the border between Virginia and West VA and approximately $30 \mathrm{~km}$ Northeast of Bluefield, VA. Regional meteorological data for precipitation, temperature and PDSI were derived from NOAA for Virginia Climatic Division 6. Ozone monitoring data were provided for 1990-2008 by the Virginia Division of Environmental Quality (VADEQ) for a rural station near Wytheville, VA. Three sections of the New River, including a 2,212 square miles upper section monitored at Allistonia, VA, the middle section monitored near Radford Virginia (2767 square miles) and the full watershed monitored at Glen Lynn were evaluated with the same basic results regarding the importance of ozone as a contributor to late season streamflow.

e. James River (JR), VA - Analysis interval: 26 yrs, 1982-2007. The upper James River drains a 525,000 ha (2,073 square mile) sparsely populated rural and predominantly forested watershed that derives from eastern West Virginia and West-Central Virginia. The monitoring station (Latitude $37^{\circ} 31^{\prime} 50^{\prime \prime}$, Longitude $79^{\circ} 40^{\prime} 45^{\prime \prime}$ ) at Buchanan, Virginia is approximately $30 \mathrm{~km}$ East of Roanoke, VA. Regional meteorological data for precipitation, temperature and PDSI were derived from NOAA for Virginia Climatic Division 5. Ozone monitoring data were provided for 1982-2008 by the Virginia Division of Environmental Quality (VADEQ) for a rural station in Roanoke County near Roanoke, VA. 
f. Fernow Experimental Watershed (FEW), WVA - Analysis interval: 18 yrs, 1989-2006. This is a USDA Forest Service long term hydrologic research installation established in 1951. It is located in mountainous areas near Parsons, West Virginia on unglaciated Allegheny Plateau with elevations ranging from 533 to 1,112 meters above sea level. The climate is characterized as rainy and cool. Mean annual precipitation is about 1,470 $\mathrm{mm}$ per year, distributed evenly throughout the year. Mean annual temperature is $8.9^{\circ} \mathrm{C}$. Vegetation is dominated by mixed upland deciduous forests. In this study, we used Watershed 4, a small (39 ha) watershed designated as a Control watershed at Fernow. Streamflow has been monitored since 1951 using a V-notch weir. Hourly ozone data were collected on site since 1989.

\section{SI 2.0 Intraregional Comparisons of Watershed Flow Characteristics and Environmental Data}

The watersheds within the study region are linked by generally similar rolling topography, heavily forested cover, and synoptic summer weather patterns dominated by Southwest to Northeast wind flow patterns and occasional area-wide air stagnation patterns. Typical time lapses of less than a week are required for frontal movement across the region. Summer air 
stagnation patterns typically emerge several times each year and result in area wide elevation of ozone, temperature, and haze. Our analyses provided several measures of this regional homogeneity. First, analysis of historical ozone exposure patterns across the region revealed differences in levels of annual exposure at various sites, but similar patterns of fluctuation at all sites (Figure SI 3.1). Linkages of other factors influencing annual variations in flow were also apparent.

A correlation matrix of annual late-season watershed flow at the six watersheds across the common interval of 1992-2006 indicated that flows were generally well correlated across the region, particularly among the largest watersheds. Pearson correlation coefficients typically ranged from 0.49 to 0.90 among flow at larger watersheds. Among smaller watershed, flow at WBWS was well correlated with that at larger watersheds (0.26 to 0.85), while flows at Fernow, the smallest and most northerly watershed were much more weakly correlated with flow at other watersheds ( 0.13 for NR (largest) to 0.49 for WBWS(next smallest)). In general watersheds were similarly influenced by similarities in synoptic weather patterns across this region. In initial exploratory analyses, for example, specific meteorological conditions, including ozone exposure at Walker Branch Watershed (WBWS) at the southwestern end of the region were found to do a surprisingly good job of predicting flow of the 2100 square mile James River Watershed (JRWS) $\left(R^{2}=0.38, p<0.05\right)$. Prediction of flows for the JRWS were substantially improved by considering the specific annual scale meteorology and ozone exposure of that watershed $\left(R^{2}=0.92\right)$, but the significant aspects of the larger regional scale meteorological patterns influenced both watersheds in similar ways.

Table SI2.1 Mean Environmental Data for the Six Watersheds

\begin{tabular}{|c|c|c|c|c|c|c|}
\hline Comparative Environmental Data ${ }^{1}$ & WBWS & LR & $\mathrm{CC}$ & NR & $\mathbf{J R}$ & FEW \\
\hline Ozone (AOT60 in PPMH) & 1.72 & 2.6 & 1.72 & 0.82 & 0.83 & 0.74 \\
\hline Ozone (MxH in PPB) & 68.2 & 67.8 & 68.2 & 59.4 & 58.7 & 58.8 \\
\hline PDSI & 1.47 & 1.43 & -0.05 & 0.34 & 0.26 & - \\
\hline Rainfall (mm/d) & 4.45 & 4.45 & 4.91 & 4.05 & 3.97 & 4.45 \\
\hline
\end{tabular}


1.Data are averages per month for the months May through September averaged over the years; 1990-2006. A site-specific calculation of regional water deficit was used in Place of Palmer Drought Severity Index (PDSI) for Fernow Watershed.

\section{SI 3.0. Historical Ozone Exposure across the Study Region}

The ozone exposure data used in these analyses originated from five locations Look Rock, TN(for Little River); Mascot, TN (for WBWS and Cataloochie Creek): Wythville, VA (for New River); Roanoke, VA (for James River); and Fernow, WV (for the Fernow reference watershed) as described in the text. In Figure SI-3 we have plotted the historical trends in ozone exposure across the region as represented by these watersheds. The exposure metric $\mathrm{O}_{3} \mathrm{AOT} 6 \mathrm{O}_{59}$ presented was identified as' significant in 3 of the 6 watershed models. Figure SI 3 represents two important aspects of ozone exposure within the study region. First, there was a clear gradient in ozone exposure with the highest values in the southwestern region and lowest values for Fernow and the James River Watershed (JRWS). Second, despite differences in levels of exposure, the year to year patterns of relative highs and lows were very similar across the region. These patterns are driven by regional similarities in air stagnation patterns that occur with a relatively high annual frequency across the region (Korschover, 1973).

We have chosen to use an exposure threshold of $60 \mathrm{nl} \mathrm{I}^{-1}$ to represent potential ozone impacts on forest water use, but other indices such as $40 \mathrm{nl} \mathrm{l}^{-1}$, which is a frequent metric in European studies, could also have been used. For comparison purposes, within our study region the seasonal (April through October) total AOT40 and AOT60 values were $34 \mathrm{ul} \mathrm{I}^{-1} \mathrm{~h}$ and $9.6 \mathrm{ul} \mathrm{I}^{-1} \mathrm{~h}$ respectively for WBWS (Mascot, TN) and $25.7 \mathrm{ul} \mathrm{I}^{-1} \mathrm{~h}$ and $4.9 \mathrm{ul} \mathrm{I}^{-1} \mathrm{~h}$ respectively for JRWS (Roanoke, VA). 


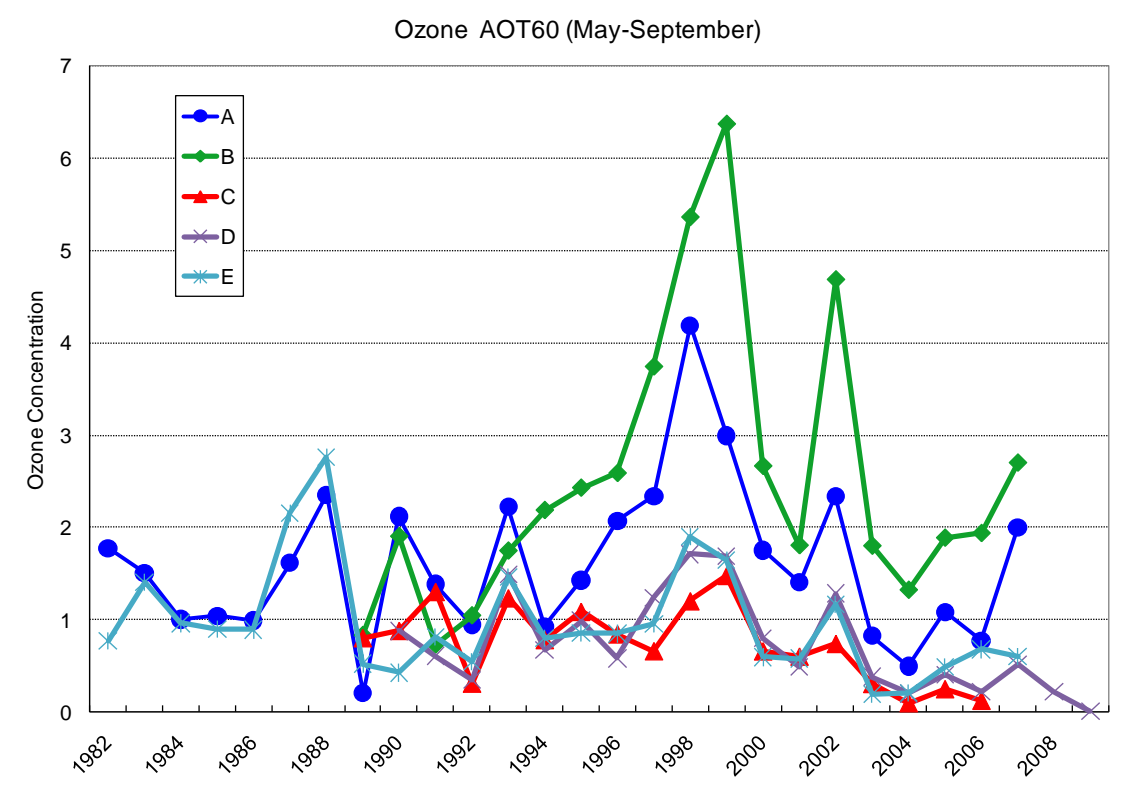

Figure SI3.1a Historical ozone trends for AOT6059 across the study region.

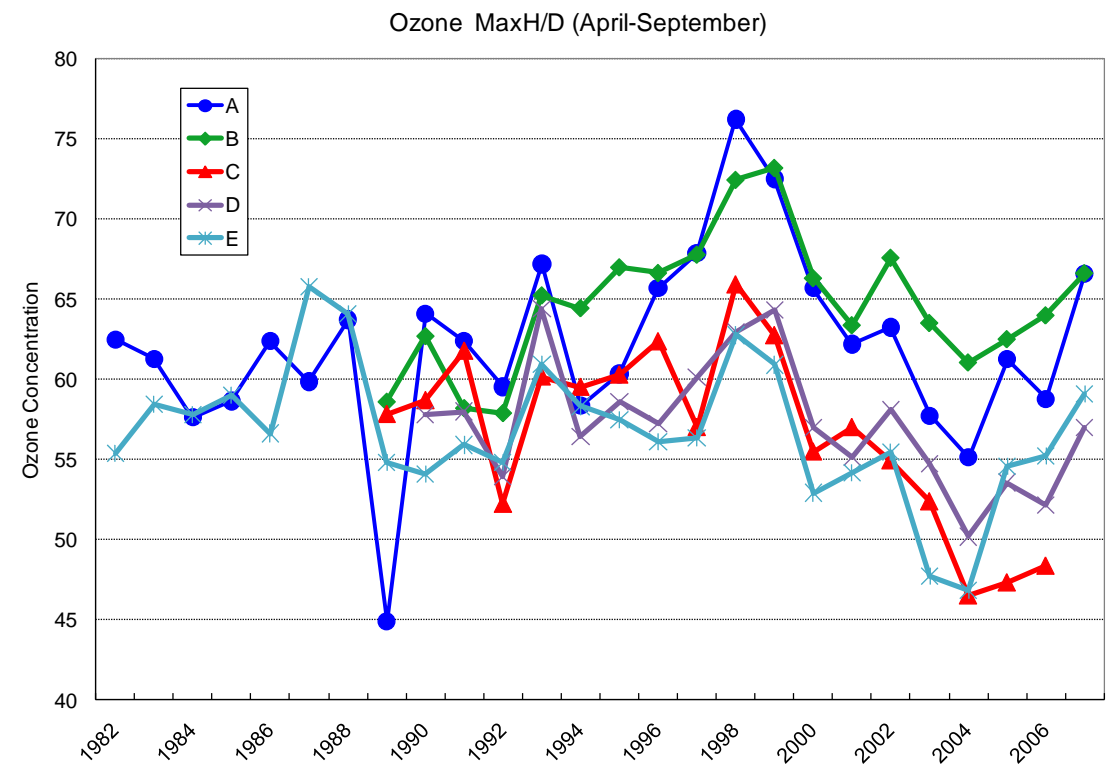

Figure SI3.1b Historical ozone trends for Hourly Maximum per Day across the study region. Where: 
$A=$ Mascot, $T N$ - source for Walker Branch Watershed and Cataloochie Creek

$B=$ Look Rock, TN - Source for the Little River at Townsend, TN

$C=$ Fernow WVA - onsite monitor for Furnow Watershed

D=Wytheville, VA - source for New River AT Gen Lyn, VA

$E=$ Roanoke, VA - source for James River at Buchanan, VA

\section{SI 4.0 Estimating the Magnitude of Ozone Effects on Relative Streamflow}

The Multiple-Partial Correlation Analysis that were presented in Table 4 of the manuscript provide conservative estimates of the percent of the long term variance in annual late-season streamflow that is contributed by annual ozone exposure or climate. The estimate is based on model predictions of actual variance.

To translate that variance into an ozone effect we have first calculated the variance of the time series of late season flow for each watershed and then translated the (\%) ozone effect into a \% of variance ( and flow in CFS).. The magnitude of that effect can then be compared to mean or minimum flow as a relative indicator of the potential of ozone to modify flow characteristics of the watershed. Thus the data shown in Table SI 4.1 combine the flow variance data for each watershed and the estimates of variance attributable to climate and ozone as derived from empirical models of historical flow for each watershed. Estimates of average effects across watersheds ranged from $15 \%-25 \%$ of mean flow for ozone and $8-44 \%$ for climate. Largest effects estimated by this method occurred at the smaller watersheds which are less "buffered" against large relative changes in flow volume by their small and less variable input catchments than larger regional watersheds. Volume flow changes of course are dependent on watershed size. Our analyses indicate that the predominant effect of ozone will be to reduce flow due to increased water use by forests. However it should be noted that in the very highest ozone years an increase in flow might occur if leaf production were reduced or leaf senescence were accelerated (See discussion by McLaughlin et al, 2007b). Nevertheless these figures provide a relative basis for comparing ozone and climate effects to each other across watersheds and over time. 
Table SI 4.1. Estimates of ozone effects on flow of six Appalachian watersheds based on model estimates of contributions of ozone and climate to variance in annual flow. Note that $C^{*} \mathrm{O}$ interactions have been omitted from the individual effects of ozone and climate presented here.

\begin{tabular}{|c|c|c|c|}
\hline Watershed & Component & $\begin{array}{l}\text { Change as a \% } \\
\text { of Mean }\end{array}$ & $\begin{array}{l}\text { Change in Flow } \\
\left(\text { feet }^{3} s^{-1}\right)\end{array}$ \\
\hline Walker Branch & Ozone & 23.3 & 0.057 \\
\hline Oak Ridge, TN & Climate & 21.6 & 0.053 \\
\hline Little River & Ozone & 27.5 & 59.8 \\
\hline GSMNP(W) Townsend, TN & Climate & 7.7 & 16.7 \\
\hline Cataloochie Creek & Ozone & 24.8 & 15.8 \\
\hline GSMNP (E), NC & Climate & 14 & 8.9 \\
\hline New River & Ozone & 17.8 & 487.8 \\
\hline Glen Lynn, VA & Climate & 16 & 438.5 \\
\hline Fernow & Ozone & 26.2 & 0.018 \\
\hline Parsons, WV & Climate & 44.2 & 0.031 \\
\hline James River & Ozone & 14.8 & 175.1 \\
\hline Buchanan, VA & Climate & 21.5 & 254.3 \\
\hline
\end{tabular}

\section{References for Supplementary Information}


Kleinbaum, D.G., Kupper, L.L., Muller, K.E., \& Nizam, A. Applied Regression Techniques.

(Kugeshev, A et al., eds. Duxbury Press, Washington, 1998)

Korshover, J., and Angell, J., A review of air stagnation cases in the eastern United States during 1981-annual summary. Mon. Weath. Rev. 110 (1982) 1515.

Palmer, W.C. Meteorological drought. (US Weather Bureau, Wash.D.C.,1965).

Statistix. 2000. Analytical software for desktop applications. Version 7.0 


\section{Supplementary Information}

\section{An Overview of Methods and Analytical Strategy}

We have included this section to expand upon both conceptual and statistical details included in the documentation of primary methods in the main text. Because this was an exploratory study we examined a diverse range of potentially useful predictor environmental variables to be used in defining factors that most strongly influenced late season streamflow. For this study late season streamflow was defined as the average monthly flow over the interval August through October. Other flow intervals were also examined, including the interval April through October, September and October, and the minimum weekly flow within the August - October interval. Similar results were found for most of these intevals. We focused on August through October as it corresponded to a period of fully mature foliage, late in the growing season, and an interval for which chonic effects from 3-4 months of previous exposure of foliage to ozone would be expected be more likely. This was based in part on our previously published studies of ozone effects on growth and water use by individual trees in Tennessee in which effects on seasonal growth patterns were more apparent late in the growing season (McLaughlin et al., 2007).

As discussed in the text, we chose as predictor environmental variables traditional measures of physical climate, temperature, PDSI, and rainfall, that were available at relevant locations across our entire study region. Ozone data were acquired from 4 regional and 1 local monitoring stations to represent the regional air quality within the airsheds in which our 6 watersheds were located. The ozone data were characterized by metrics that decades of air pollution research tell us can be important in defining potentially phytotoxic levels of exposure to ozone. They included averages of both hourly peak concentrations each day, and accumulated exposure doses at and above $60 \mathrm{nl} / \mathrm{l}$, a frequently used threshhold for phytotoxicity (Fowler, 1999),. For all environmental data we used monthly averages over intervals that would most logically influence both biological and physical limitations on water flow through hydrologic pathways from the atmosphere, through processing forests to streams. These were segmented into 2 to 7 month, sometimes overlapping, averaging intervals to capture phenotypic variations expected and found across the $430 \mathrm{~km}$ North -South latitudinal gradient encompassing the 6 study sites.

The combination of 6 primary indicators (3 physical climate and 3 ozone variables) and four product terms to capture drought (PDSI)* Ozone interactions (see SI 2.0), gave us 34 total possible environmental predictors to consider - an excessive number to test en mass with only 26 years of streamflow data. We approached this task by restricting initial analyses to predictor subsets that were determined to most closely correlate with streamflow and by initially 
analyzing ozone and climate data subsets separately to determine which sets of variables were most effective as streamflow predictors. In this process the ultimate model building was done using Best Regression Analysis (Kleinbaum et al., 1998) to identify the best combinations of predictor variables from subsets of 14 or fewer candidates. These were selected from equal numbers of candidate ozone and climate predictor variables to assure equal chances of ozone and climate variables appearing in the final model.

We have conducted numerous tests to validate the statistical validity and predictive capacity of the streamflow models we have developed in this process. The validity of the ozone signal was verified both by determining that models based solely on climate were consistently and significantly improved by the addition of ozone predictor terms and by measuring the effects of removal of ozone variables from the best models developed with both climate and ozone predictors. The Multiple-Partial Correlation Analysis by which we made separate estimates of ozone and climate signals in complete models, which had 7-11 predictor variables, was also used to estimate the influence of model size and complexity on the relative magnitude of estimates of both ozone and climate influences. For both the Walker Branch Watershed (WBWS) and the New River Watershed (NRWS), estimates of both ozone and ozone climate interactions as well as estimates of climate plus climate*ozone interactions steadily improved and stayed in the same relative ratio to eachother as overall model $\mathrm{R} 2$ improved at all levels from $\mathrm{N}=3$ to $\mathrm{N}=11$. For WBWS, estimates of the influences of $\mathrm{O}+\mathrm{O} * \mathrm{C}$ averaged $27 \%$ and increased from $25 \%$ at $\mathrm{N}=3$ to $27 \%$ at $\mathrm{N}=11$. Influences of $\mathrm{C}+\mathrm{C}^{*} \mathrm{O}$ averaged $50 \%$ of $\mathrm{R} 2$ and increased from $42 \%$ at $\mathrm{N}=3$ to $62 \%$ at $\mathrm{N}=11$. Similarly, for NRWS $\mathrm{O}+\mathrm{O}^{*} \mathrm{C}$ influences ranged from $11 \%$ at $\mathrm{N}=3$ to $15 \%$ at $\mathrm{N}=10$, while $\mathrm{C}+\mathrm{C}^{*} \mathrm{O}$ was more stable, ranging from $64 \%$ at $\mathrm{N}=3$ to $62 \%$ at $\mathrm{N}=10$. Thus estimates of contributions of climate and ozone components in the models were rather consistent across models at increasing levels of complexity.

The possibility of overfitting models was also explored by determining that models developed from subsets of the same data were consistent in form and fit to the data. In addition the consistencies in form and fit to watershed flow data across watersheds also support the strength and validity of models developed by these methods of variable definition and selection. Variable subsets identified as important at one watershed worked well at other watersheds. A separate test to estimate relative contributions of annual differences in patterns of ozone and climate to annual differences in flow between the Walker Branch and New River Watersheds identified annual differences in ozone exposure as being relatively more important than differences in climatic factors in contributing to these annual flow differences. 
More detailed descriptions of methodological procedures in these studies can be found in the following sections: Watershed Characteristics and Data Sources (SI 1.0); Intraregional Comparisons of Watershed Flow Characteristics and Environmental Data_(SI 2.0); Historical Ozone Exposures Across the Study Region (SI 3.0); and Estimating the Relative Magnitude of Ozone Effects on Streamflow (SI 4.0).

\section{SI1.0 Watershed Characteristics and Data}

The locations of all watersheds examined in these studies are noted in Figure 1 of the main text. The direction of flow is indicated by area proportional triangles with the downstream apex located at the position of the monitoring stations. The two largest watersheds examined the Upper James ( 525,000 ha) and the New River $(970,000$ ha) were estimated by land cover maps to be at least $75 \%$ in mature second growth forests. The remaining four watersheds were estimated at $>95 \%$ forest cover. All watersheds were typically forested with mixed deciduous forests typically dominated by oaks, hickories, and yellow poplar.

a. Walker Branch Watershed (WBWS), TN - Analysis interval: 26 yrs, 1982-2007. Located at Oak Ridge, Tennessee, this research watershed is comprised of a total of 98 ha of forested hills at $\mathbf{2 0 0 - 3 0 0 ~ m ~ i n ~ e l e v a t i o n . ~ T h e ~ w a t e r s h e d ~ h a s ~ b e e n ~ m a i n t a i n e d ~ a s ~ a ~ l o n g ~}$ term research facility by Oak Ridge National Laboratory (ORNL) for the Department of Energy and its predecessor agencies since 1969. Estimated forest cover is $>99 \%$. Flow, temperature, and precipitation data for 1982-2007 were acquired from the Walker Branch Watershed website: (http://walkerbranch.ornl.gov). Regional Palmer Drought Severity Index (PDSI) data were derived from National Atmospheric and Oceanic Administration (NOAA) for Tennessee Climate Division 6. Ozone data were provided for the Mascot, TN station located approximately $30 \mathrm{~km}$ East of from Oak Ridge. This station is maintained by the State of Tennessee, Division of Air Quality.

b. Little River (LR), TN - Analysis interval: 19 yrs, 1989-2007. The Little River, monitored at Townsend Tennessee, comprises over 28,000 ha (106 square miles) of forest lands located along the western slopes of the Great Smoky Mountains National Park. This watershed ranges in elevation from 200 to $2300 \mathrm{~m}$ and is fully forested. Temperature, precipitation and ozone data for 1982-2007 were provided by Jim Renfro, Air Quality Specialist with the National Park Service from a monitoring station maintained at Look Rock TN. The Look Rock Station is located at $750 \mathrm{~m}$ elevation at ridge crest approximately $30 \mathrm{~km}$ east of the Townsend, stream gauging station. Regional Palmer 
Drought Severity Index (PDSI) data were derived from NOAA for Tennessee Climate Division 6. Streamflow data were obtained from the US Geological Survey (USGS).

c. Cataloochee Creek (CC), NC-Analysis interval: 26 yrs, 1982-2007. The USGS gauging streamflow gauging station for this watershed is at latitude $35^{\circ} 40^{\prime} 02^{\prime \prime}$ and longitude $83^{\circ} 04^{\prime} 22^{\prime \prime}$. The basin drains $127 \mathrm{~km}^{2}$ of steep, mountainous fully forested terrain that ranges in elevation from $749 \mathrm{~m}$ at the gage to $1,876 \mathrm{~m}$. The main channel is perennial with a mean monthly discharge varying from $1.5 \mathrm{~m}^{3} / \mathrm{s}$ during low flow in September and October to $5.7 \mathrm{~m}^{3} / \mathrm{s}$ in March when spring rains combine with snowmelt. Average annual runoff from the basin was $78 \mathrm{~cm}$ from 1934 through 1995 (U.S. Geological Survey, Water Resources Data, North Carolina). Climate of the area is characterized by abundant precipitation and moderate temperatures. Mean monthly air temperatures range from $4^{\circ} \mathrm{C}$ in December to $23^{\circ} \mathrm{C}$ in July at an elevation of $445 \mathrm{~m}$ and $0^{\circ} \mathrm{C}$ in March to $16^{\circ} \mathrm{C}$ in July at an elevation of $1,920 \mathrm{~m}$.

d. New River (NR), VA - Analysis interval: 19 yrs, 1990-2008. The New River Watershed drains approximately 970,000 hectares ( 3768 Square miles) of predominantly forested (>80\% forest) mountain lands in Southwestern Virginia. The stream gauge is maintained by the US Geological Survey at Glen Lynn, VA near the border between Virginia and West VA and approximately $30 \mathrm{~km}$ Northeast of Bluefield, VA. Regional meteorological data for precipitation, temperature and PDSI were derived from NOAA for Virginia Climatic Division 6. Ozone monitoring data were provided for 1990-2008 by the Virginia Division of Environmental Quality (VADEQ) for a rural station near Wytheville, VA. Three sections of the New River, including a 2,212 square miles upper section monitored at Allistonia, VA, the middle section monitored near Radford Virginia (2767 square miles) and the full watershed monitored at Glen Lynn were evaluated with the same basic results regarding the importance of ozone as a contributor to late season streamflow.

e. James River (JR), VA - Analysis interval: 26 yrs, 1982-2007. The upper James River drains a 525,000 ha (2,073 square mile) sparsely populated rural and predominantly forested watershed that derives from eastern West Virginia and West-Central Virginia. The monitoring station (Latitude $37^{\circ} 31^{\prime} 50^{\prime \prime}$, Longitude $79^{\circ} 40^{\prime} 45^{\prime \prime}$ ) at Buchanan, Virginia is approximately $30 \mathrm{~km}$ East of Roanoke, VA. Regional meteorological data for precipitation, temperature and PDSI were derived from NOAA for Virginia Climatic Division 5. Ozone monitoring data were provided for 1982-2008 by the Virginia Division of Environmental Quality (VADEQ) for a rural station in Roanoke County near Roanoke, VA. 
f. Fernow Experimental Watershed (FEW), WVA - Analysis interval: 18 yrs, 1989-2006. This is a USDA Forest Service long term hydrologic research installation established in 1951. It is located in mountainous areas near Parsons, West Virginia on unglaciated Allegheny Plateau with elevations ranging from 533 to 1,112 meters above sea level. The climate is characterized as rainy and cool. Mean annual precipitation is about 1,470 $\mathrm{mm}$ per year, distributed evenly throughout the year. Mean annual temperature is $8.9^{\circ} \mathrm{C}$. Vegetation is dominated by mixed upland deciduous forests. In this study, we used Watershed 4, a small (39 ha) watershed designated as a Control watershed at Fernow. Streamflow has been monitored since 1951 using a V-notch weir. Hourly ozone data were collected on site since 1989.

\section{SI 2.0 Intraregional Comparisons of Watershed Flow Characteristics and Environmental Data}

The watersheds within the study region are linked by generally similar rolling topography, heavily forested cover, and synoptic summer weather patterns dominated by Southwest to Northeast wind flow patterns and occasional area-wide air stagnation patterns. Typical time lapses of less than a week are required for frontal movement across the region. Summer air 
stagnation patterns typically emerge several times each year and result in area wide elevation of ozone, temperature, and haze. Our analyses provided several measures of this regional homogeneity. First, analysis of historical ozone exposure patterns across the region revealed differences in levels of annual exposure at various sites, but similar patterns of fluctuation at all sites (Figure SI 3.1). Linkages of other factors influencing annual variations in flow were also apparent.

A correlation matrix of annual late-season watershed flow at the six watersheds across the common interval of 1992-2006 indicated that flows were generally well correlated across the region, particularly among the largest watersheds. Pearson correlation coefficients typically ranged from 0.49 to 0.90 among flow at larger watersheds. Among smaller watershed, flow at WBWS was well correlated with that at larger watersheds (0.26 to 0.85), while flows at Fernow, the smallest and most northerly watershed were much more weakly correlated with flow at other watersheds ( 0.13 for NR (largest) to 0.49 for WBWS(next smallest)). In general watersheds were similarly influenced by similarities in synoptic weather patterns across this region. In initial exploratory analyses, for example, specific meteorological conditions, including ozone exposure at Walker Branch Watershed (WBWS) at the southwestern end of the region were found to do a surprisingly good job of predicting flow of the 2100 square mile James River Watershed (JRWS) $\left(R^{2}=0.38, p<0.05\right)$. Prediction of flows for the JRWS were substantially improved by considering the specific annual scale meteorology and ozone exposure of that watershed $\left(R^{2}=0.92\right)$, but the significant aspects of the larger regional scale meteorological patterns influenced both watersheds in similar ways.

Table SI2.1 Mean Environmental Data for the Six Watersheds

\begin{tabular}{|c|c|c|c|c|c|c|}
\hline Comparative Environmental Data ${ }^{1}$ & WBWS & LR & $\mathrm{CC}$ & NR & $\mathbf{J R}$ & FEW \\
\hline Ozone (AOT60 in PPMH) & 1.72 & 2.6 & 1.72 & 0.82 & 0.83 & 0.74 \\
\hline Ozone (MxH in PPB) & 68.2 & 67.8 & 68.2 & 59.4 & 58.7 & 58.8 \\
\hline PDSI & 1.47 & 1.43 & -0.05 & 0.34 & 0.26 & - \\
\hline Rainfall (mm/d) & 4.45 & 4.45 & 4.91 & 4.05 & 3.97 & 4.45 \\
\hline
\end{tabular}


1.Data are averages per month for the months May through September averaged over the years; 1990-2006. A site-specific calculation of regional water deficit was used in Place of Palmer Drought Severity Index (PDSI) for Fernow Watershed.

\section{SI 3.0. Historical Ozone Exposure across the Study Region}

The ozone exposure data used in these analyses originated from five locations Look Rock, TN(for Little River); Mascot, TN (for WBWS and Cataloochie Creek): Wythville, VA (for New River); Roanoke, VA (for James River); and Fernow, WV (for the Fernow reference watershed) as described in the text. In Figure SI-3 we have plotted the historical trends in ozone exposure across the region as represented by these watersheds. The exposure metric $\mathrm{O}_{3} \mathrm{AOT} 6 \mathrm{O}_{59}$ presented was identified as' significant in 3 of the 6 watershed models. Figure SI 3 represents two important aspects of ozone exposure within the study region. First, there was a clear gradient in ozone exposure with the highest values in the southwestern region and lowest values for Fernow and the James River Watershed (JRWS). Second, despite differences in levels of exposure, the year to year patterns of relative highs and lows were very similar across the region. These patterns are driven by regional similarities in air stagnation patterns that occur with a relatively high annual frequency across the region (Korschover, 1973).

We have chosen to use an exposure threshold of $60 \mathrm{nl} \mathrm{I}^{-1}$ to represent potential ozone impacts on forest water use, but other indices such as $40 \mathrm{nl} \mathrm{l}^{-1}$, which is a frequent metric in European studies, could also have been used. For comparison purposes, within our study region the seasonal (April through October) total AOT40 and AOT60 values were $34 \mathrm{ul} \mathrm{I}^{-1} \mathrm{~h}$ and $9.6 \mathrm{ul} \mathrm{I}^{-1} \mathrm{~h}$ respectively for WBWS (Mascot, TN) and $25.7 \mathrm{ul} \mathrm{I}^{-1} \mathrm{~h}$ and $4.9 \mathrm{ul} \mathrm{I}^{-1} \mathrm{~h}$ respectively for JRWS (Roanoke, VA). 


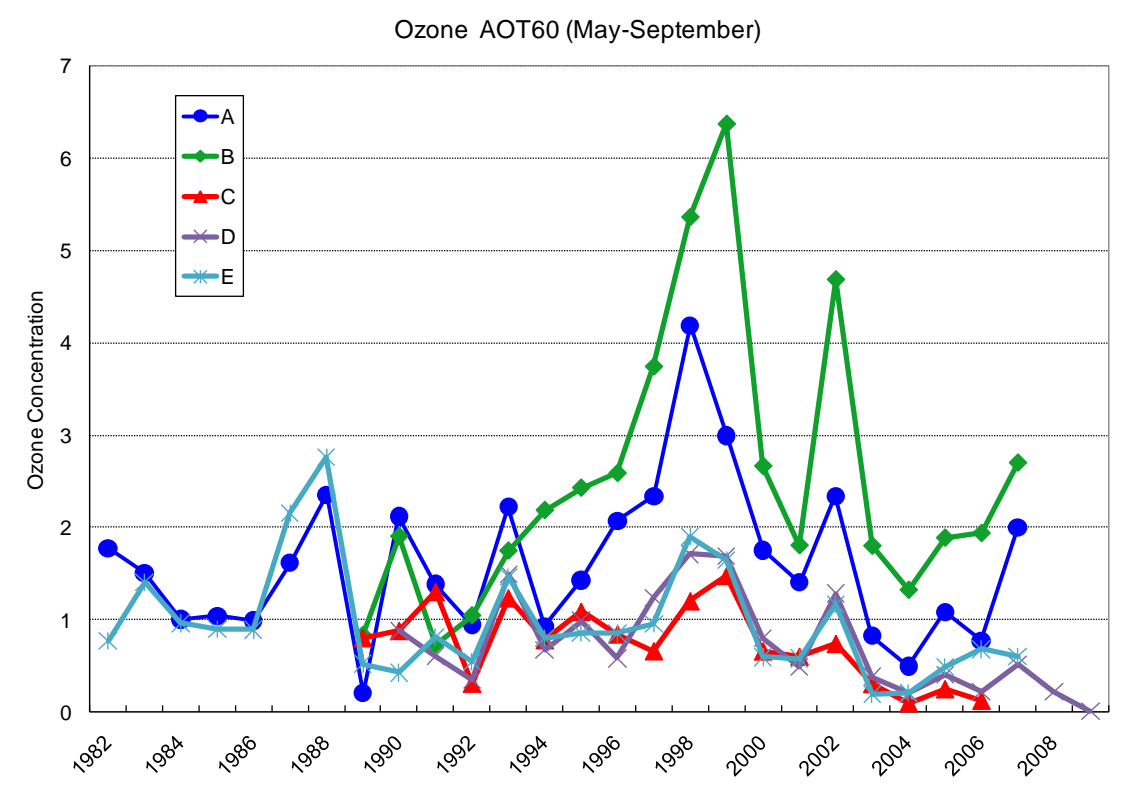

Figure SI3.1a Historical ozone trends for AOT6059 across the study region.

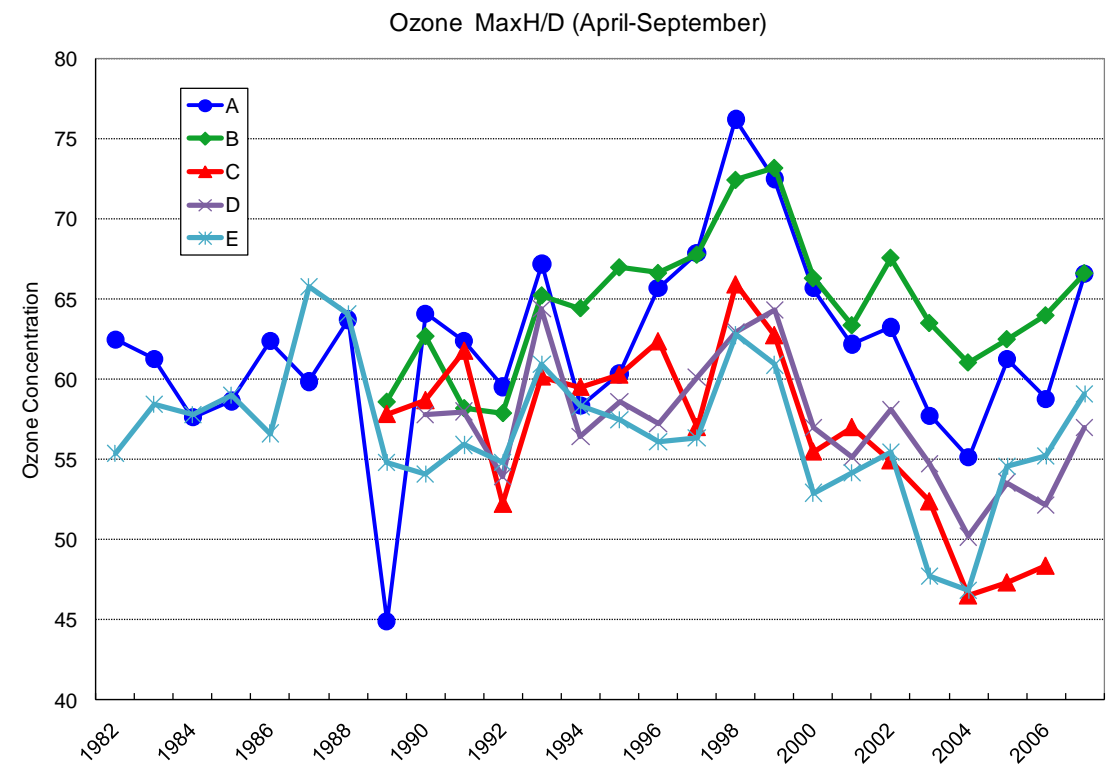

Figure SI3.1b Historical ozone trends for Hourly Maximum per Day across the study region. Where: 
$A=$ Mascot, $T N$ - source for Walker Branch Watershed and Cataloochie Creek

$B=$ Look Rock, TN - Source for the Little River at Townsend, TN

$C=$ Fernow WVA - onsite monitor for Furnow Watershed

D=Wytheville, VA - source for New River AT Gen Lyn, VA

$E=$ Roanoke, VA - source for James River at Buchanan, VA

\section{SI 4.0 Estimating the Magnitude of Ozone Effects on Relative Streamflow}

The Multiple-Partial Correlation Analysis that were presented in Table 4 of the manuscript provide conservative estimates of the percent of the long term variance in annual late-season streamflow that is contributed by annual ozone exposure or climate. The estimate is based on model predictions of actual variance.

To translate that variance into an ozone effect we have first calculated the variance of the time series of late season flow for each watershed and then translated the (\%) ozone effect into a \% of variance ( and flow in CFS).. The magnitude of that effect can then be compared to mean or minimum flow as a relative indicator of the potential of ozone to modify flow characteristics of the watershed. Thus the data shown in Table SI 4.1 combine the flow variance data for each watershed and the estimates of variance attributable to climate and ozone as derived from empirical models of historical flow for each watershed. Estimates of average effects across watersheds ranged from $15 \%-25 \%$ of mean flow for ozone and $8-44 \%$ for climate. Largest effects estimated by this method occurred at the smaller watersheds which are less "buffered" against large relative changes in flow volume by their small and less variable input catchments than larger regional watersheds. Volume flow changes of course are dependent on watershed size. Our analyses indicate that the predominant effect of ozone will be to reduce flow due to increased water use by forests. However it should be noted that in the very highest ozone years an increase in flow might occur if leaf production were reduced or leaf senescence were accelerated (See discussion by McLaughlin et al, 2007b). Nevertheless these figures provide a relative basis for comparing ozone and climate effects to each other across watersheds and over time. 
Table SI 4.1. Estimates of ozone effects on flow of six Appalachian watersheds based on model estimates of contributions of ozone and climate to variance in annual flow. Note that $C^{*} \mathrm{O}$ interactions have been omitted from the individual effects of ozone and climate presented here.

\begin{tabular}{|c|c|c|c|}
\hline Watershed & Component & $\begin{array}{l}\text { Change as a \% } \\
\text { of Mean }\end{array}$ & $\begin{array}{l}\text { Change in Flow } \\
\left(\text { feet }^{3} s^{-1}\right)\end{array}$ \\
\hline Walker Branch & Ozone & 23.3 & 0.057 \\
\hline Oak Ridge, TN & Climate & 21.6 & 0.053 \\
\hline Little River & Ozone & 27.5 & 59.8 \\
\hline GSMNP(W) Townsend, TN & Climate & 7.7 & 16.7 \\
\hline Cataloochie Creek & Ozone & 24.8 & 15.8 \\
\hline GSMNP (E), NC & Climate & 14 & 8.9 \\
\hline New River & Ozone & 17.8 & 487.8 \\
\hline Glen Lynn, VA & Climate & 16 & 438.5 \\
\hline Fernow & Ozone & 26.2 & 0.018 \\
\hline Parsons, WV & Climate & 44.2 & 0.031 \\
\hline James River & Ozone & 14.8 & 175.1 \\
\hline Buchanan, VA & Climate & 21.5 & 254.3 \\
\hline
\end{tabular}

\section{References for Supplementary Information}


Kleinbaum, D.G., Kupper, L.L., Muller, K.E., \& Nizam, A. Applied Regression Techniques.

(Kugeshev, A et al., eds. Duxbury Press, Washington, 1998)

Korshover, J., and Angell, J., A review of air stagnation cases in the eastern United States during 1981-annual summary. Mon. Weath. Rev. 110 (1982) 1515.

Palmer, W.C. Meteorological drought. (US Weather Bureau, Wash.D.C.,1965).

Statistix. 2000. Analytical software for desktop applications. Version 7.0 


\section{Supplementary Information}

\section{An Overview of Methods and Analytical Strategy}

We have included this section to expand upon both conceptual and statistical details included in the documentation of primary methods in the main text. Because this was an exploratory study we examined a diverse range of potentially useful predictor environmental variables to be used in defining factors that most strongly influenced late season streamflow. For this study late season streamflow was defined as the average monthly flow over the interval August through October. Other flow intervals were also examined, including the interval April through October, September and October, and the minimum weekly flow within the August - October interval. Similar results were found for most of these intevals. We focused on August through October as it corresponded to a period of fully mature foliage, late in the growing season, and an interval for which chonic effects from 3-4 months of previous exposure of foliage to ozone would be expected be more likely. This was based in part on our previously published studies of ozone effects on growth and water use by individual trees in Tennessee in which effects on seasonal growth patterns were more apparent late in the growing season (McLaughlin et al., 2007).

As discussed in the text, we chose as predictor environmental variables traditional measures of physical climate, temperature, PDSI, and rainfall, that were available at relevant locations across our entire study region. Ozone data were acquired from 4 regional and 1 local monitoring stations to represent the regional air quality within the airsheds in which our 6 watersheds were located. The ozone data were characterized by metrics that decades of air pollution research tell us can be important in defining potentially phytotoxic levels of exposure to ozone. They included averages of both hourly peak concentrations each day, and accumulated exposure doses at and above $60 \mathrm{nl} / \mathrm{l}$, a frequently used threshhold for phytotoxicity (Fowler, 1999),. For all environmental data we used monthly averages over intervals that would most logically influence both biological and physical limitations on water flow through hydrologic pathways from the atmosphere, through processing forests to streams. These were segmented into 2 to 7 month, sometimes overlapping, averaging intervals to capture phenotypic variations expected and found across the $430 \mathrm{~km}$ North -South latitudinal gradient encompassing the 6 study sites.

The combination of 6 primary indicators (3 physical climate and 3 ozone variables) and four product terms to capture drought (PDSI)* Ozone interactions (see SI 2.0), gave us 34 total possible environmental predictors to consider - an excessive number to test en mass with only 26 years of streamflow data. We approached this task by restricting initial analyses to predictor subsets that were determined to most closely correlate with streamflow and by initially 
analyzing ozone and climate data subsets separately to determine which sets of variables were most effective as streamflow predictors. In this process the ultimate model building was done using Best Regression Analysis (Kleinbaum et al., 1998) to identify the best combinations of predictor variables from subsets of 14 or fewer candidates. These were selected from equal numbers of candidate ozone and climate predictor variables to assure equal chances of ozone and climate variables appearing in the final model.

We have conducted numerous tests to validate the statistical validity and predictive capacity of the streamflow models we have developed in this process. The validity of the ozone signal was verified both by determining that models based solely on climate were consistently and significantly improved by the addition of ozone predictor terms and by measuring the effects of removal of ozone variables from the best models developed with both climate and ozone predictors. The Multiple-Partial Correlation Analysis by which we made separate estimates of ozone and climate signals in complete models, which had 7-11 predictor variables, was also used to estimate the influence of model size and complexity on the relative magnitude of estimates of both ozone and climate influences. For both the Walker Branch Watershed (WBWS) and the New River Watershed (NRWS), estimates of both ozone and ozone climate interactions as well as estimates of climate plus climate*ozone interactions steadily improved and stayed in the same relative ratio to eachother as overall model $\mathrm{R} 2$ improved at all levels from $\mathrm{N}=3$ to $\mathrm{N}=11$. For WBWS, estimates of the influences of $\mathrm{O}+\mathrm{O} * \mathrm{C}$ averaged $27 \%$ and increased from $25 \%$ at $\mathrm{N}=3$ to $27 \%$ at $\mathrm{N}=11$. Influences of $\mathrm{C}+\mathrm{C}^{*} \mathrm{O}$ averaged $50 \%$ of $\mathrm{R} 2$ and increased from $42 \%$ at $\mathrm{N}=3$ to $62 \%$ at $\mathrm{N}=11$. Similarly, for NRWS $\mathrm{O}+\mathrm{O}^{*} \mathrm{C}$ influences ranged from $11 \%$ at $\mathrm{N}=3$ to $15 \%$ at $\mathrm{N}=10$, while $\mathrm{C}+\mathrm{C}^{*} \mathrm{O}$ was more stable, ranging from $64 \%$ at $\mathrm{N}=3$ to $62 \%$ at $\mathrm{N}=10$. Thus estimates of contributions of climate and ozone components in the models were rather consistent across models at increasing levels of complexity.

The possibility of overfitting models was also explored by determining that models developed from subsets of the same data were consistent in form and fit to the data. In addition the consistencies in form and fit to watershed flow data across watersheds also support the strength and validity of models developed by these methods of variable definition and selection. Variable subsets identified as important at one watershed worked well at other watersheds. A separate test to estimate relative contributions of annual differences in patterns of ozone and climate to annual differences in flow between the Walker Branch and New River Watersheds identified annual differences in ozone exposure as being relatively more important than differences in climatic factors in contributing to these annual flow differences. 
More detailed descriptions of methodological procedures in these studies can be found in the following sections: Watershed Characteristics and Data Sources (SI 1.0); Intraregional Comparisons of Watershed Flow Characteristics and Environmental Data_(SI 2.0); Historical Ozone Exposures Across the Study Region (SI 3.0); and Estimating the Relative Magnitude of Ozone Effects on Streamflow (SI 4.0).

\section{SI1.0 Watershed Characteristics and Data}

The locations of all watersheds examined in these studies are noted in Figure 1 of the main text. The direction of flow is indicated by area proportional triangles with the downstream apex located at the position of the monitoring stations. The two largest watersheds examined the Upper James ( 525,000 ha) and the New River $(970,000$ ha) were estimated by land cover maps to be at least $75 \%$ in mature second growth forests. The remaining four watersheds were estimated at $>95 \%$ forest cover. All watersheds were typically forested with mixed deciduous forests typically dominated by oaks, hickories, and yellow poplar.

a. Walker Branch Watershed (WBWS), TN - Analysis interval: 26 yrs, 1982-2007. Located at Oak Ridge, Tennessee, this research watershed is comprised of a total of 98 ha of forested hills at $\mathbf{2 0 0 - 3 0 0 ~ m ~ i n ~ e l e v a t i o n . ~ T h e ~ w a t e r s h e d ~ h a s ~ b e e n ~ m a i n t a i n e d ~ a s ~ a ~ l o n g ~}$ term research facility by Oak Ridge National Laboratory (ORNL) for the Department of Energy and its predecessor agencies since 1969. Estimated forest cover is $>99 \%$. Flow, temperature, and precipitation data for 1982-2007 were acquired from the Walker Branch Watershed website: (http://walkerbranch.ornl.gov). Regional Palmer Drought Severity Index (PDSI) data were derived from National Atmospheric and Oceanic Administration (NOAA) for Tennessee Climate Division 6. Ozone data were provided for the Mascot, TN station located approximately $30 \mathrm{~km}$ East of from Oak Ridge. This station is maintained by the State of Tennessee, Division of Air Quality.

b. Little River (LR), TN - Analysis interval: 19 yrs, 1989-2007. The Little River, monitored at Townsend Tennessee, comprises over 28,000 ha (106 square miles) of forest lands located along the western slopes of the Great Smoky Mountains National Park. This watershed ranges in elevation from 200 to $2300 \mathrm{~m}$ and is fully forested. Temperature, precipitation and ozone data for 1982-2007 were provided by Jim Renfro, Air Quality Specialist with the National Park Service from a monitoring station maintained at Look Rock TN. The Look Rock Station is located at $750 \mathrm{~m}$ elevation at ridge crest approximately $30 \mathrm{~km}$ east of the Townsend, stream gauging station. Regional Palmer 
Drought Severity Index (PDSI) data were derived from NOAA for Tennessee Climate Division 6. Streamflow data were obtained from the US Geological Survey (USGS).

c. Cataloochee Creek (CC), NC-Analysis interval: 26 yrs, 1982-2007. The USGS gauging streamflow gauging station for this watershed is at latitude $35^{\circ} 40^{\prime} 02^{\prime \prime}$ and longitude $83^{\circ} 04^{\prime} 22^{\prime \prime}$. The basin drains $127 \mathrm{~km}^{2}$ of steep, mountainous fully forested terrain that ranges in elevation from $749 \mathrm{~m}$ at the gage to $1,876 \mathrm{~m}$. The main channel is perennial with a mean monthly discharge varying from $1.5 \mathrm{~m}^{3} / \mathrm{s}$ during low flow in September and October to $5.7 \mathrm{~m}^{3} / \mathrm{s}$ in March when spring rains combine with snowmelt. Average annual runoff from the basin was $78 \mathrm{~cm}$ from 1934 through 1995 (U.S. Geological Survey, Water Resources Data, North Carolina). Climate of the area is characterized by abundant precipitation and moderate temperatures. Mean monthly air temperatures range from $4^{\circ} \mathrm{C}$ in December to $23^{\circ} \mathrm{C}$ in July at an elevation of $445 \mathrm{~m}$ and $0^{\circ} \mathrm{C}$ in March to $16^{\circ} \mathrm{C}$ in July at an elevation of $1,920 \mathrm{~m}$.

d. New River (NR), VA - Analysis interval: 19 yrs, 1990-2008. The New River Watershed drains approximately 970,000 hectares ( 3768 Square miles) of predominantly forested (>80\% forest) mountain lands in Southwestern Virginia. The stream gauge is maintained by the US Geological Survey at Glen Lynn, VA near the border between Virginia and West VA and approximately $30 \mathrm{~km}$ Northeast of Bluefield, VA. Regional meteorological data for precipitation, temperature and PDSI were derived from NOAA for Virginia Climatic Division 6. Ozone monitoring data were provided for 1990-2008 by the Virginia Division of Environmental Quality (VADEQ) for a rural station near Wytheville, VA. Three sections of the New River, including a 2,212 square miles upper section monitored at Allistonia, VA, the middle section monitored near Radford Virginia (2767 square miles) and the full watershed monitored at Glen Lynn were evaluated with the same basic results regarding the importance of ozone as a contributor to late season streamflow.

e. James River (JR), VA - Analysis interval: 26 yrs, 1982-2007. The upper James River drains a 525,000 ha (2,073 square mile) sparsely populated rural and predominantly forested watershed that derives from eastern West Virginia and West-Central Virginia. The monitoring station (Latitude $37^{\circ} 31^{\prime} 50^{\prime \prime}$, Longitude $79^{\circ} 40^{\prime} 45^{\prime \prime}$ ) at Buchanan, Virginia is approximately $30 \mathrm{~km}$ East of Roanoke, VA. Regional meteorological data for precipitation, temperature and PDSI were derived from NOAA for Virginia Climatic Division 5. Ozone monitoring data were provided for 1982-2008 by the Virginia Division of Environmental Quality (VADEQ) for a rural station in Roanoke County near Roanoke, VA. 
f. Fernow Experimental Watershed (FEW), WVA - Analysis interval: 18 yrs, 1989-2006. This is a USDA Forest Service long term hydrologic research installation established in 1951. It is located in mountainous areas near Parsons, West Virginia on unglaciated Allegheny Plateau with elevations ranging from 533 to 1,112 meters above sea level. The climate is characterized as rainy and cool. Mean annual precipitation is about 1,470 $\mathrm{mm}$ per year, distributed evenly throughout the year. Mean annual temperature is $8.9^{\circ} \mathrm{C}$. Vegetation is dominated by mixed upland deciduous forests. In this study, we used Watershed 4, a small (39 ha) watershed designated as a Control watershed at Fernow. Streamflow has been monitored since 1951 using a V-notch weir. Hourly ozone data were collected on site since 1989.

\section{SI 2.0 Intraregional Comparisons of Watershed Flow Characteristics and Environmental Data}

The watersheds within the study region are linked by generally similar rolling topography, heavily forested cover, and synoptic summer weather patterns dominated by Southwest to Northeast wind flow patterns and occasional area-wide air stagnation patterns. Typical time lapses of less than a week are required for frontal movement across the region. Summer air 
stagnation patterns typically emerge several times each year and result in area wide elevation of ozone, temperature, and haze. Our analyses provided several measures of this regional homogeneity. First, analysis of historical ozone exposure patterns across the region revealed differences in levels of annual exposure at various sites, but similar patterns of fluctuation at all sites (Figure SI 3.1). Linkages of other factors influencing annual variations in flow were also apparent.

A correlation matrix of annual late-season watershed flow at the six watersheds across the common interval of 1992-2006 indicated that flows were generally well correlated across the region, particularly among the largest watersheds. Pearson correlation coefficients typically ranged from 0.49 to 0.90 among flow at larger watersheds. Among smaller watershed, flow at WBWS was well correlated with that at larger watersheds (0.26 to 0.85), while flows at Fernow, the smallest and most northerly watershed were much more weakly correlated with flow at other watersheds ( 0.13 for NR (largest) to 0.49 for WBWS(next smallest)). In general watersheds were similarly influenced by similarities in synoptic weather patterns across this region. In initial exploratory analyses, for example, specific meteorological conditions, including ozone exposure at Walker Branch Watershed (WBWS) at the southwestern end of the region were found to do a surprisingly good job of predicting flow of the 2100 square mile James River Watershed (JRWS) $\left(R^{2}=0.38, p<0.05\right)$. Prediction of flows for the JRWS were substantially improved by considering the specific annual scale meteorology and ozone exposure of that watershed $\left(R^{2}=0.92\right)$, but the significant aspects of the larger regional scale meteorological patterns influenced both watersheds in similar ways.

Table SI2.1 Mean Environmental Data for the Six Watersheds

\begin{tabular}{|c|c|c|c|c|c|c|}
\hline Comparative Environmental Data ${ }^{1}$ & WBWS & LR & $\mathrm{CC}$ & NR & $\mathbf{J R}$ & FEW \\
\hline Ozone (AOT60 in PPMH) & 1.72 & 2.6 & 1.72 & 0.82 & 0.83 & 0.74 \\
\hline Ozone (MxH in PPB) & 68.2 & 67.8 & 68.2 & 59.4 & 58.7 & 58.8 \\
\hline PDSI & 1.47 & 1.43 & -0.05 & 0.34 & 0.26 & - \\
\hline Rainfall (mm/d) & 4.45 & 4.45 & 4.91 & 4.05 & 3.97 & 4.45 \\
\hline
\end{tabular}


1.Data are averages per month for the months May through September averaged over the years; 1990-2006. A site-specific calculation of regional water deficit was used in Place of Palmer Drought Severity Index (PDSI) for Fernow Watershed.

\section{SI 3.0. Historical Ozone Exposure across the Study Region}

The ozone exposure data used in these analyses originated from five locations Look Rock, TN(for Little River); Mascot, TN (for WBWS and Cataloochie Creek): Wythville, VA (for New River); Roanoke, VA (for James River); and Fernow, WV (for the Fernow reference watershed) as described in the text. In Figure SI-3 we have plotted the historical trends in ozone exposure across the region as represented by these watersheds. The exposure metric $\mathrm{O}_{3} \mathrm{AOT} 6 \mathrm{O}_{59}$ presented was identified as' significant in 3 of the 6 watershed models. Figure SI 3 represents two important aspects of ozone exposure within the study region. First, there was a clear gradient in ozone exposure with the highest values in the southwestern region and lowest values for Fernow and the James River Watershed (JRWS). Second, despite differences in levels of exposure, the year to year patterns of relative highs and lows were very similar across the region. These patterns are driven by regional similarities in air stagnation patterns that occur with a relatively high annual frequency across the region (Korschover, 1973).

We have chosen to use an exposure threshold of $60 \mathrm{nl} \mathrm{I}^{-1}$ to represent potential ozone impacts on forest water use, but other indices such as $40 \mathrm{nl} \mathrm{l}^{-1}$, which is a frequent metric in European studies, could also have been used. For comparison purposes, within our study region the seasonal (April through October) total AOT40 and AOT60 values were $34 \mathrm{ul} \mathrm{I}^{-1} \mathrm{~h}$ and $9.6 \mathrm{ul} \mathrm{I}^{-1} \mathrm{~h}$ respectively for WBWS (Mascot, TN) and $25.7 \mathrm{ul} \mathrm{I}^{-1} \mathrm{~h}$ and $4.9 \mathrm{ul} \mathrm{I}^{-1} \mathrm{~h}$ respectively for JRWS (Roanoke, VA). 


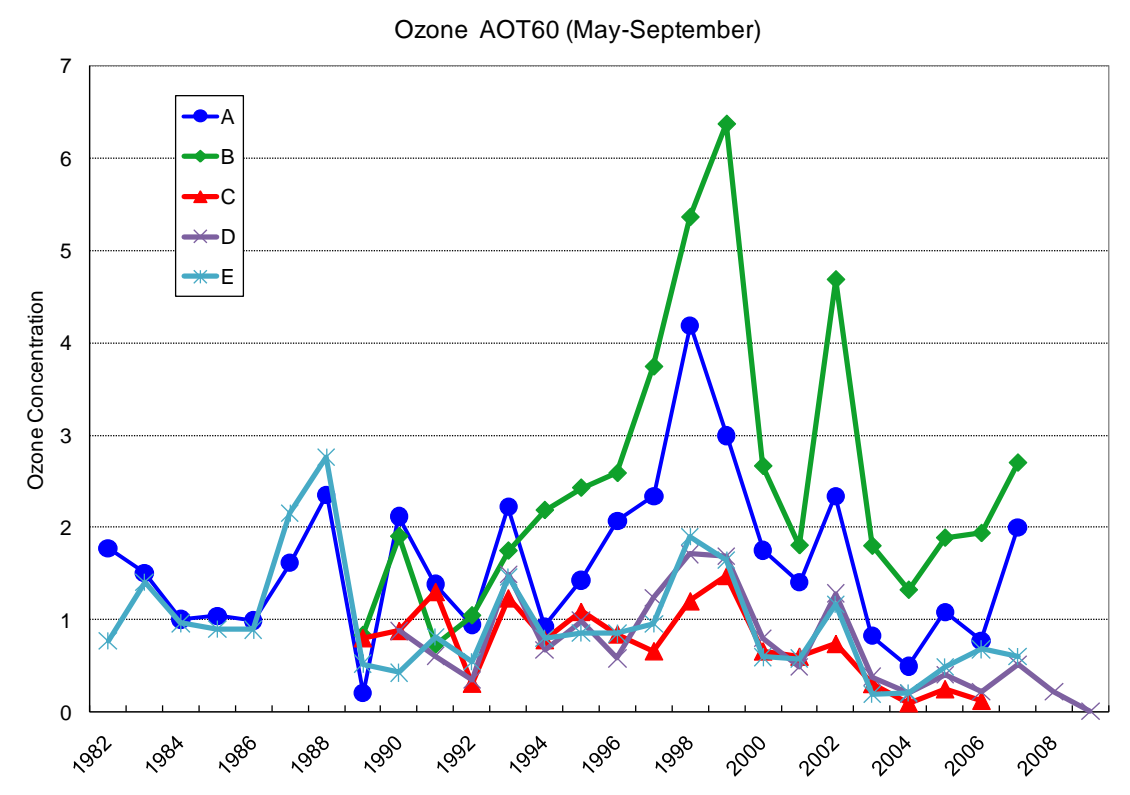

Figure SI3.1a Historical ozone trends for AOT6059 across the study region.

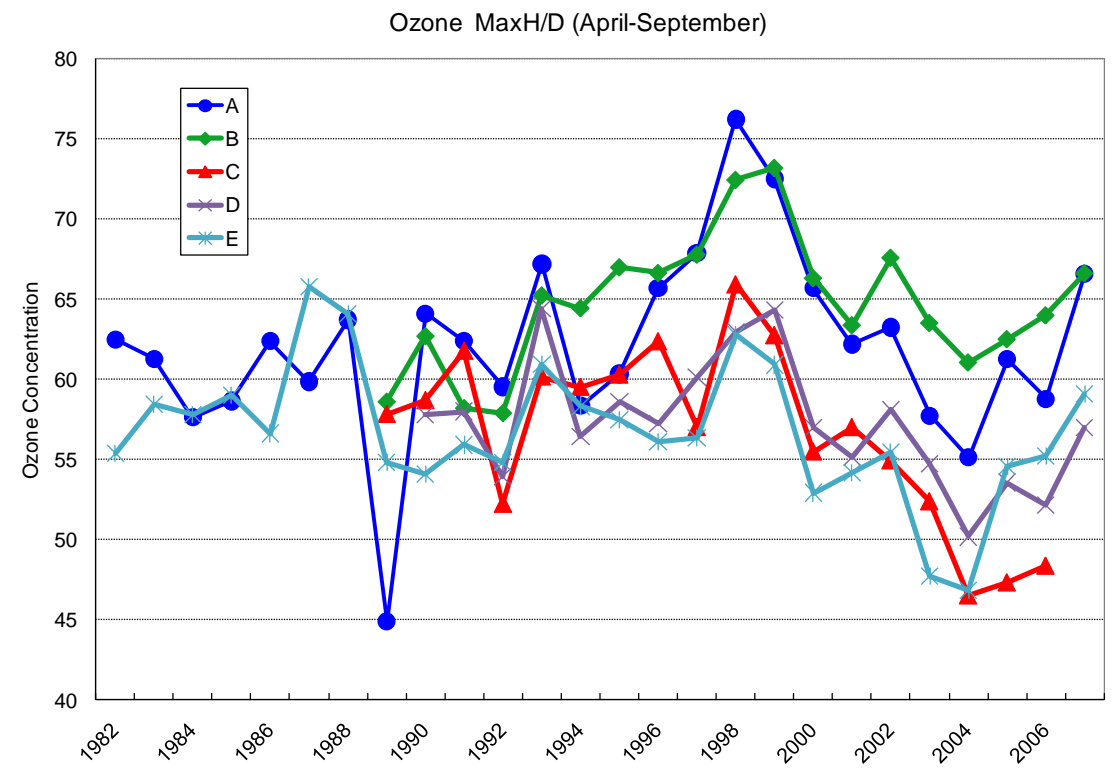

Figure SI3.1b Historical ozone trends for Hourly Maximum per Day across the study region. Where: 
$A=$ Mascot, $T N$ - source for Walker Branch Watershed and Cataloochie Creek

$B=$ Look Rock, TN - Source for the Little River at Townsend, TN

$C=$ Fernow WVA - onsite monitor for Furnow Watershed

D=Wytheville, VA - source for New River AT Gen Lyn, VA

$E=$ Roanoke, VA - source for James River at Buchanan, VA

\section{SI 4.0 Estimating the Magnitude of Ozone Effects on Relative Streamflow}

The Multiple-Partial Correlation Analysis that were presented in Table 4 of the manuscript provide conservative estimates of the percent of the long term variance in annual late-season streamflow that is contributed by annual ozone exposure or climate. The estimate is based on model predictions of actual variance.

To translate that variance into an ozone effect we have first calculated the variance of the time series of late season flow for each watershed and then translated the (\%) ozone effect into a \% of variance ( and flow in CFS).. The magnitude of that effect can then be compared to mean or minimum flow as a relative indicator of the potential of ozone to modify flow characteristics of the watershed. Thus the data shown in Table SI 4.1 combine the flow variance data for each watershed and the estimates of variance attributable to climate and ozone as derived from empirical models of historical flow for each watershed. Estimates of average effects across watersheds ranged from $15 \%-25 \%$ of mean flow for ozone and $8-44 \%$ for climate. Largest effects estimated by this method occurred at the smaller watersheds which are less "buffered" against large relative changes in flow volume by their small and less variable input catchments than larger regional watersheds. Volume flow changes of course are dependent on watershed size. Our analyses indicate that the predominant effect of ozone will be to reduce flow due to increased water use by forests. However it should be noted that in the very highest ozone years an increase in flow might occur if leaf production were reduced or leaf senescence were accelerated (See discussion by McLaughlin et al, 2007b). Nevertheless these figures provide a relative basis for comparing ozone and climate effects to each other across watersheds and over time. 
Table SI 4.1. Estimates of ozone effects on flow of six Appalachian watersheds based on model estimates of contributions of ozone and climate to variance in annual flow. Note that $C^{*} \mathrm{O}$ interactions have been omitted from the individual effects of ozone and climate presented here.

\begin{tabular}{|c|c|c|c|}
\hline Watershed & Component & $\begin{array}{l}\text { Change as a \% } \\
\text { of Mean }\end{array}$ & $\begin{array}{l}\text { Change in Flow } \\
\left(\text { feet }^{3} s^{-1}\right)\end{array}$ \\
\hline Walker Branch & Ozone & 23.3 & 0.057 \\
\hline Oak Ridge, TN & Climate & 21.6 & 0.053 \\
\hline Little River & Ozone & 27.5 & 59.8 \\
\hline GSMNP(W) Townsend, TN & Climate & 7.7 & 16.7 \\
\hline Cataloochie Creek & Ozone & 24.8 & 15.8 \\
\hline GSMNP (E), NC & Climate & 14 & 8.9 \\
\hline New River & Ozone & 17.8 & 487.8 \\
\hline Glen Lynn, VA & Climate & 16 & 438.5 \\
\hline Fernow & Ozone & 26.2 & 0.018 \\
\hline Parsons, WV & Climate & 44.2 & 0.031 \\
\hline James River & Ozone & 14.8 & 175.1 \\
\hline Buchanan, VA & Climate & 21.5 & 254.3 \\
\hline
\end{tabular}

\section{References for Supplementary Information}


Kleinbaum, D.G., Kupper, L.L., Muller, K.E., \& Nizam, A. Applied Regression Techniques.

(Kugeshev, A et al., eds. Duxbury Press, Washington, 1998)

Korshover, J., and Angell, J., A review of air stagnation cases in the eastern United States during 1981-annual summary. Mon. Weath. Rev. 110 (1982) 1515.

Palmer, W.C. Meteorological drought. (US Weather Bureau, Wash.D.C.,1965).

Statistix. 2000. Analytical software for desktop applications. Version 7.0 


\section{Supplementary Information}

\section{An Overview of Methods and Analytical Strategy}

We have included this section to expand upon both conceptual and statistical details included in the documentation of primary methods in the main text. Because this was an exploratory study we examined a diverse range of potentially useful predictor environmental variables to be used in defining factors that most strongly influenced late season streamflow. For this study late season streamflow was defined as the average monthly flow over the interval August through October. Other flow intervals were also examined, including the interval April through October, September and October, and the minimum weekly flow within the August - October interval. Similar results were found for most of these intevals. We focused on August through October as it corresponded to a period of fully mature foliage, late in the growing season, and an interval for which chonic effects from 3-4 months of previous exposure of foliage to ozone would be expected be more likely. This was based in part on our previously published studies of ozone effects on growth and water use by individual trees in Tennessee in which effects on seasonal growth patterns were more apparent late in the growing season (McLaughlin et al., 2007).

As discussed in the text, we chose as predictor environmental variables traditional measures of physical climate, temperature, PDSI, and rainfall, that were available at relevant locations across our entire study region. Ozone data were acquired from 4 regional and 1 local monitoring stations to represent the regional air quality within the airsheds in which our 6 watersheds were located. The ozone data were characterized by metrics that decades of air pollution research tell us can be important in defining potentially phytotoxic levels of exposure to ozone. They included averages of both hourly peak concentrations each day, and accumulated exposure doses at and above $60 \mathrm{nl} / \mathrm{l}$, a frequently used threshhold for phytotoxicity (Fowler, 1999),. For all environmental data we used monthly averages over intervals that would most logically influence both biological and physical limitations on water flow through hydrologic pathways from the atmosphere, through processing forests to streams. These were segmented into 2 to 7 month, sometimes overlapping, averaging intervals to capture phenotypic variations expected and found across the $430 \mathrm{~km}$ North -South latitudinal gradient encompassing the 6 study sites.

The combination of 6 primary indicators (3 physical climate and 3 ozone variables) and four product terms to capture drought (PDSI)* Ozone interactions (see SI 2.0), gave us 34 total possible environmental predictors to consider - an excessive number to test en mass with only 26 years of streamflow data. We approached this task by restricting initial analyses to predictor subsets that were determined to most closely correlate with streamflow and by initially 
analyzing ozone and climate data subsets separately to determine which sets of variables were most effective as streamflow predictors. In this process the ultimate model building was done using Best Regression Analysis (Kleinbaum et al., 1998) to identify the best combinations of predictor variables from subsets of 14 or fewer candidates. These were selected from equal numbers of candidate ozone and climate predictor variables to assure equal chances of ozone and climate variables appearing in the final model.

We have conducted numerous tests to validate the statistical validity and predictive capacity of the streamflow models we have developed in this process. The validity of the ozone signal was verified both by determining that models based solely on climate were consistently and significantly improved by the addition of ozone predictor terms and by measuring the effects of removal of ozone variables from the best models developed with both climate and ozone predictors. The Multiple-Partial Correlation Analysis by which we made separate estimates of ozone and climate signals in complete models, which had 7-11 predictor variables, was also used to estimate the influence of model size and complexity on the relative magnitude of estimates of both ozone and climate influences. For both the Walker Branch Watershed (WBWS) and the New River Watershed (NRWS), estimates of both ozone and ozone climate interactions as well as estimates of climate plus climate*ozone interactions steadily improved and stayed in the same relative ratio to eachother as overall model $\mathrm{R} 2$ improved at all levels from $\mathrm{N}=3$ to $\mathrm{N}=11$. For WBWS, estimates of the influences of $\mathrm{O}+\mathrm{O} * \mathrm{C}$ averaged $27 \%$ and increased from $25 \%$ at $\mathrm{N}=3$ to $27 \%$ at $\mathrm{N}=11$. Influences of $\mathrm{C}+\mathrm{C}^{*} \mathrm{O}$ averaged $50 \%$ of $\mathrm{R} 2$ and increased from $42 \%$ at $\mathrm{N}=3$ to $62 \%$ at $\mathrm{N}=11$. Similarly, for NRWS $\mathrm{O}+\mathrm{O}^{*} \mathrm{C}$ influences ranged from $11 \%$ at $\mathrm{N}=3$ to $15 \%$ at $\mathrm{N}=10$, while $\mathrm{C}+\mathrm{C}^{*} \mathrm{O}$ was more stable, ranging from $64 \%$ at $\mathrm{N}=3$ to $62 \%$ at $\mathrm{N}=10$. Thus estimates of contributions of climate and ozone components in the models were rather consistent across models at increasing levels of complexity.

The possibility of overfitting models was also explored by determining that models developed from subsets of the same data were consistent in form and fit to the data. In addition the consistencies in form and fit to watershed flow data across watersheds also support the strength and validity of models developed by these methods of variable definition and selection. Variable subsets identified as important at one watershed worked well at other watersheds. A separate test to estimate relative contributions of annual differences in patterns of ozone and climate to annual differences in flow between the Walker Branch and New River Watersheds identified annual differences in ozone exposure as being relatively more important than differences in climatic factors in contributing to these annual flow differences. 
More detailed descriptions of methodological procedures in these studies can be found in the following sections: Watershed Characteristics and Data Sources (SI 1.0); Intraregional Comparisons of Watershed Flow Characteristics and Environmental Data_(SI 2.0); Historical Ozone Exposures Across the Study Region (SI 3.0); and Estimating the Relative Magnitude of Ozone Effects on Streamflow (SI 4.0).

\section{SI1.0 Watershed Characteristics and Data}

The locations of all watersheds examined in these studies are noted in Figure 1 of the main text. The direction of flow is indicated by area proportional triangles with the downstream apex located at the position of the monitoring stations. The two largest watersheds examined the Upper James ( 525,000 ha) and the New River $(970,000$ ha) were estimated by land cover maps to be at least $75 \%$ in mature second growth forests. The remaining four watersheds were estimated at $>95 \%$ forest cover. All watersheds were typically forested with mixed deciduous forests typically dominated by oaks, hickories, and yellow poplar.

a. Walker Branch Watershed (WBWS), TN - Analysis interval: 26 yrs, 1982-2007. Located at Oak Ridge, Tennessee, this research watershed is comprised of a total of 98 ha of forested hills at $\mathbf{2 0 0 - 3 0 0 ~ m ~ i n ~ e l e v a t i o n . ~ T h e ~ w a t e r s h e d ~ h a s ~ b e e n ~ m a i n t a i n e d ~ a s ~ a ~ l o n g ~}$ term research facility by Oak Ridge National Laboratory (ORNL) for the Department of Energy and its predecessor agencies since 1969. Estimated forest cover is $>99 \%$. Flow, temperature, and precipitation data for 1982-2007 were acquired from the Walker Branch Watershed website: (http://walkerbranch.ornl.gov). Regional Palmer Drought Severity Index (PDSI) data were derived from National Atmospheric and Oceanic Administration (NOAA) for Tennessee Climate Division 6. Ozone data were provided for the Mascot, TN station located approximately $30 \mathrm{~km}$ East of from Oak Ridge. This station is maintained by the State of Tennessee, Division of Air Quality.

b. Little River (LR), TN - Analysis interval: 19 yrs, 1989-2007. The Little River, monitored at Townsend Tennessee, comprises over 28,000 ha (106 square miles) of forest lands located along the western slopes of the Great Smoky Mountains National Park. This watershed ranges in elevation from 200 to $2300 \mathrm{~m}$ and is fully forested. Temperature, precipitation and ozone data for 1982-2007 were provided by Jim Renfro, Air Quality Specialist with the National Park Service from a monitoring station maintained at Look Rock TN. The Look Rock Station is located at $750 \mathrm{~m}$ elevation at ridge crest approximately $30 \mathrm{~km}$ east of the Townsend, stream gauging station. Regional Palmer 
Drought Severity Index (PDSI) data were derived from NOAA for Tennessee Climate Division 6. Streamflow data were obtained from the US Geological Survey (USGS).

c. Cataloochee Creek (CC), NC-Analysis interval: 26 yrs, 1982-2007. The USGS gauging streamflow gauging station for this watershed is at latitude $35^{\circ} 40^{\prime} 02^{\prime \prime}$ and longitude $83^{\circ} 04^{\prime} 22^{\prime \prime}$. The basin drains $127 \mathrm{~km}^{2}$ of steep, mountainous fully forested terrain that ranges in elevation from $749 \mathrm{~m}$ at the gage to $1,876 \mathrm{~m}$. The main channel is perennial with a mean monthly discharge varying from $1.5 \mathrm{~m}^{3} / \mathrm{s}$ during low flow in September and October to $5.7 \mathrm{~m}^{3} / \mathrm{s}$ in March when spring rains combine with snowmelt. Average annual runoff from the basin was $78 \mathrm{~cm}$ from 1934 through 1995 (U.S. Geological Survey, Water Resources Data, North Carolina). Climate of the area is characterized by abundant precipitation and moderate temperatures. Mean monthly air temperatures range from $4^{\circ} \mathrm{C}$ in December to $23^{\circ} \mathrm{C}$ in July at an elevation of $445 \mathrm{~m}$ and $0^{\circ} \mathrm{C}$ in March to $16^{\circ} \mathrm{C}$ in July at an elevation of $1,920 \mathrm{~m}$.

d. New River (NR), VA - Analysis interval: 19 yrs, 1990-2008. The New River Watershed drains approximately 970,000 hectares ( 3768 Square miles) of predominantly forested (>80\% forest) mountain lands in Southwestern Virginia. The stream gauge is maintained by the US Geological Survey at Glen Lynn, VA near the border between Virginia and West VA and approximately $30 \mathrm{~km}$ Northeast of Bluefield, VA. Regional meteorological data for precipitation, temperature and PDSI were derived from NOAA for Virginia Climatic Division 6. Ozone monitoring data were provided for 1990-2008 by the Virginia Division of Environmental Quality (VADEQ) for a rural station near Wytheville, VA. Three sections of the New River, including a 2,212 square miles upper section monitored at Allistonia, VA, the middle section monitored near Radford Virginia (2767 square miles) and the full watershed monitored at Glen Lynn were evaluated with the same basic results regarding the importance of ozone as a contributor to late season streamflow.

e. James River (JR), VA - Analysis interval: 26 yrs, 1982-2007. The upper James River drains a 525,000 ha (2,073 square mile) sparsely populated rural and predominantly forested watershed that derives from eastern West Virginia and West-Central Virginia. The monitoring station (Latitude $37^{\circ} 31^{\prime} 50^{\prime \prime}$, Longitude $79^{\circ} 40^{\prime} 45^{\prime \prime}$ ) at Buchanan, Virginia is approximately $30 \mathrm{~km}$ East of Roanoke, VA. Regional meteorological data for precipitation, temperature and PDSI were derived from NOAA for Virginia Climatic Division 5. Ozone monitoring data were provided for 1982-2008 by the Virginia Division of Environmental Quality (VADEQ) for a rural station in Roanoke County near Roanoke, VA. 
f. Fernow Experimental Watershed (FEW), WVA - Analysis interval: 18 yrs, 1989-2006. This is a USDA Forest Service long term hydrologic research installation established in 1951. It is located in mountainous areas near Parsons, West Virginia on unglaciated Allegheny Plateau with elevations ranging from 533 to 1,112 meters above sea level. The climate is characterized as rainy and cool. Mean annual precipitation is about 1,470 $\mathrm{mm}$ per year, distributed evenly throughout the year. Mean annual temperature is $8.9^{\circ} \mathrm{C}$. Vegetation is dominated by mixed upland deciduous forests. In this study, we used Watershed 4, a small (39 ha) watershed designated as a Control watershed at Fernow. Streamflow has been monitored since 1951 using a V-notch weir. Hourly ozone data were collected on site since 1989.

\section{SI 2.0 Intraregional Comparisons of Watershed Flow Characteristics and Environmental Data}

The watersheds within the study region are linked by generally similar rolling topography, heavily forested cover, and synoptic summer weather patterns dominated by Southwest to Northeast wind flow patterns and occasional area-wide air stagnation patterns. Typical time lapses of less than a week are required for frontal movement across the region. Summer air 
stagnation patterns typically emerge several times each year and result in area wide elevation of ozone, temperature, and haze. Our analyses provided several measures of this regional homogeneity. First, analysis of historical ozone exposure patterns across the region revealed differences in levels of annual exposure at various sites, but similar patterns of fluctuation at all sites (Figure SI 3.1). Linkages of other factors influencing annual variations in flow were also apparent.

A correlation matrix of annual late-season watershed flow at the six watersheds across the common interval of 1992-2006 indicated that flows were generally well correlated across the region, particularly among the largest watersheds. Pearson correlation coefficients typically ranged from 0.49 to 0.90 among flow at larger watersheds. Among smaller watershed, flow at WBWS was well correlated with that at larger watersheds (0.26 to 0.85), while flows at Fernow, the smallest and most northerly watershed were much more weakly correlated with flow at other watersheds ( 0.13 for NR (largest) to 0.49 for WBWS(next smallest)). In general watersheds were similarly influenced by similarities in synoptic weather patterns across this region. In initial exploratory analyses, for example, specific meteorological conditions, including ozone exposure at Walker Branch Watershed (WBWS) at the southwestern end of the region were found to do a surprisingly good job of predicting flow of the 2100 square mile James River Watershed (JRWS) $\left(R^{2}=0.38, p<0.05\right)$. Prediction of flows for the JRWS were substantially improved by considering the specific annual scale meteorology and ozone exposure of that watershed $\left(R^{2}=0.92\right)$, but the significant aspects of the larger regional scale meteorological patterns influenced both watersheds in similar ways.

Table SI2.1 Mean Environmental Data for the Six Watersheds

\begin{tabular}{|c|c|c|c|c|c|c|}
\hline Comparative Environmental Data ${ }^{1}$ & WBWS & LR & $\mathrm{CC}$ & NR & $\mathbf{J R}$ & FEW \\
\hline Ozone (AOT60 in PPMH) & 1.72 & 2.6 & 1.72 & 0.82 & 0.83 & 0.74 \\
\hline Ozone (MxH in PPB) & 68.2 & 67.8 & 68.2 & 59.4 & 58.7 & 58.8 \\
\hline PDSI & 1.47 & 1.43 & -0.05 & 0.34 & 0.26 & - \\
\hline Rainfall (mm/d) & 4.45 & 4.45 & 4.91 & 4.05 & 3.97 & 4.45 \\
\hline
\end{tabular}


1.Data are averages per month for the months May through September averaged over the years; 1990-2006. A site-specific calculation of regional water deficit was used in Place of Palmer Drought Severity Index (PDSI) for Fernow Watershed.

\section{SI 3.0. Historical Ozone Exposure across the Study Region}

The ozone exposure data used in these analyses originated from five locations Look Rock, TN(for Little River); Mascot, TN (for WBWS and Cataloochie Creek): Wythville, VA (for New River); Roanoke, VA (for James River); and Fernow, WV (for the Fernow reference watershed) as described in the text. In Figure SI-3 we have plotted the historical trends in ozone exposure across the region as represented by these watersheds. The exposure metric $\mathrm{O}_{3} \mathrm{AOT} 6 \mathrm{O}_{59}$ presented was identified as' significant in 3 of the 6 watershed models. Figure SI 3 represents two important aspects of ozone exposure within the study region. First, there was a clear gradient in ozone exposure with the highest values in the southwestern region and lowest values for Fernow and the James River Watershed (JRWS). Second, despite differences in levels of exposure, the year to year patterns of relative highs and lows were very similar across the region. These patterns are driven by regional similarities in air stagnation patterns that occur with a relatively high annual frequency across the region (Korschover, 1973).

We have chosen to use an exposure threshold of $60 \mathrm{nl} \mathrm{I}^{-1}$ to represent potential ozone impacts on forest water use, but other indices such as $40 \mathrm{nl} \mathrm{l}^{-1}$, which is a frequent metric in European studies, could also have been used. For comparison purposes, within our study region the seasonal (April through October) total AOT40 and AOT60 values were $34 \mathrm{ul} \mathrm{I}^{-1} \mathrm{~h}$ and $9.6 \mathrm{ul} \mathrm{I}^{-1} \mathrm{~h}$ respectively for WBWS (Mascot, TN) and $25.7 \mathrm{ul} \mathrm{I}^{-1} \mathrm{~h}$ and $4.9 \mathrm{ul} \mathrm{I}^{-1} \mathrm{~h}$ respectively for JRWS (Roanoke, VA). 


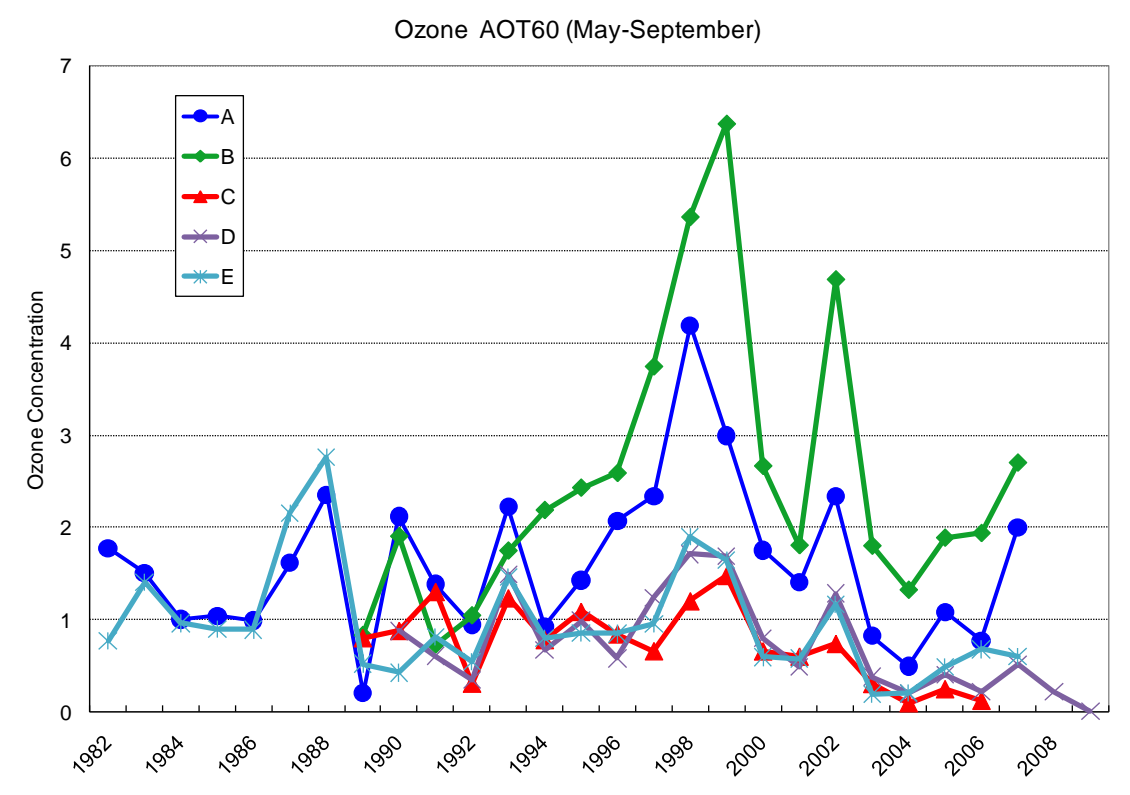

Figure SI3.1a Historical ozone trends for AOT6059 across the study region.

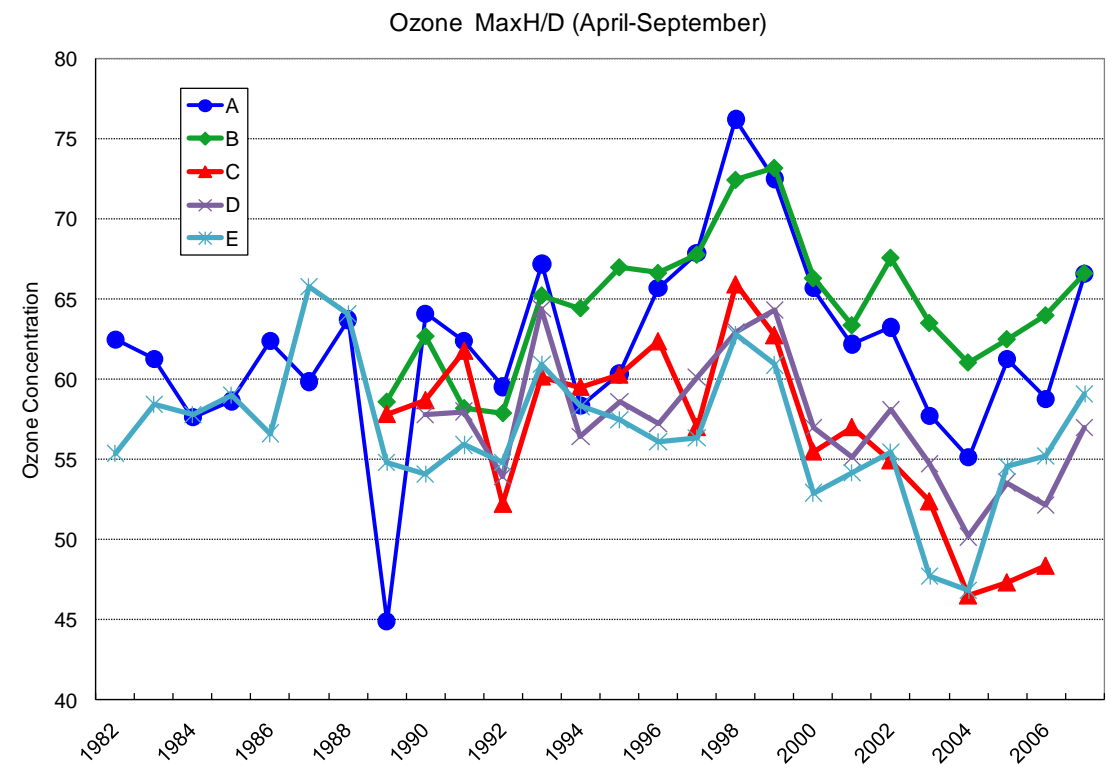

Figure SI3.1b Historical ozone trends for Hourly Maximum per Day across the study region. Where: 
$A=$ Mascot, $T N$ - source for Walker Branch Watershed and Cataloochie Creek

$B=$ Look Rock, TN - Source for the Little River at Townsend, TN

$C=$ Fernow WVA - onsite monitor for Furnow Watershed

D=Wytheville, VA - source for New River AT Gen Lyn, VA

$E=$ Roanoke, VA - source for James River at Buchanan, VA

\section{SI 4.0 Estimating the Magnitude of Ozone Effects on Relative Streamflow}

The Multiple-Partial Correlation Analysis that were presented in Table 4 of the manuscript provide conservative estimates of the percent of the long term variance in annual late-season streamflow that is contributed by annual ozone exposure or climate. The estimate is based on model predictions of actual variance.

To translate that variance into an ozone effect we have first calculated the variance of the time series of late season flow for each watershed and then translated the (\%) ozone effect into a \% of variance ( and flow in CFS).. The magnitude of that effect can then be compared to mean or minimum flow as a relative indicator of the potential of ozone to modify flow characteristics of the watershed. Thus the data shown in Table SI 4.1 combine the flow variance data for each watershed and the estimates of variance attributable to climate and ozone as derived from empirical models of historical flow for each watershed. Estimates of average effects across watersheds ranged from $15 \%-25 \%$ of mean flow for ozone and $8-44 \%$ for climate. Largest effects estimated by this method occurred at the smaller watersheds which are less "buffered" against large relative changes in flow volume by their small and less variable input catchments than larger regional watersheds. Volume flow changes of course are dependent on watershed size. Our analyses indicate that the predominant effect of ozone will be to reduce flow due to increased water use by forests. However it should be noted that in the very highest ozone years an increase in flow might occur if leaf production were reduced or leaf senescence were accelerated (See discussion by McLaughlin et al, 2007b). Nevertheless these figures provide a relative basis for comparing ozone and climate effects to each other across watersheds and over time. 
Table SI 4.1. Estimates of ozone effects on flow of six Appalachian watersheds based on model estimates of contributions of ozone and climate to variance in annual flow. Note that $C^{*} \mathrm{O}$ interactions have been omitted from the individual effects of ozone and climate presented here.

\begin{tabular}{|c|c|c|c|}
\hline Watershed & Component & $\begin{array}{l}\text { Change as a \% } \\
\text { of Mean }\end{array}$ & $\begin{array}{l}\text { Change in Flow } \\
\left(\text { feet }^{3} s^{-1}\right)\end{array}$ \\
\hline Walker Branch & Ozone & 23.3 & 0.057 \\
\hline Oak Ridge, TN & Climate & 21.6 & 0.053 \\
\hline Little River & Ozone & 27.5 & 59.8 \\
\hline GSMNP(W) Townsend, TN & Climate & 7.7 & 16.7 \\
\hline Cataloochie Creek & Ozone & 24.8 & 15.8 \\
\hline GSMNP (E), NC & Climate & 14 & 8.9 \\
\hline New River & Ozone & 17.8 & 487.8 \\
\hline Glen Lynn, VA & Climate & 16 & 438.5 \\
\hline Fernow & Ozone & 26.2 & 0.018 \\
\hline Parsons, WV & Climate & 44.2 & 0.031 \\
\hline James River & Ozone & 14.8 & 175.1 \\
\hline Buchanan, VA & Climate & 21.5 & 254.3 \\
\hline
\end{tabular}

\section{References for Supplementary Information}


Kleinbaum, D.G., Kupper, L.L., Muller, K.E., \& Nizam, A. Applied Regression Techniques.

(Kugeshev, A et al., eds. Duxbury Press, Washington, 1998)

Korshover, J., and Angell, J., A review of air stagnation cases in the eastern United States during 1981-annual summary. Mon. Weath. Rev. 110 (1982) 1515.

Palmer, W.C. Meteorological drought. (US Weather Bureau, Wash.D.C.,1965).

Statistix. 2000. Analytical software for desktop applications. Version 7.0 


\section{Supplementary Information}

\section{An Overview of Methods and Analytical Strategy}

We have included this section to expand upon both conceptual and statistical details included in the documentation of primary methods in the main text. Because this was an exploratory study we examined a diverse range of potentially useful predictor environmental variables to be used in defining factors that most strongly influenced late season streamflow. For this study late season streamflow was defined as the average monthly flow over the interval August through October. Other flow intervals were also examined, including the interval April through October, September and October, and the minimum weekly flow within the August - October interval. Similar results were found for most of these intevals. We focused on August through October as it corresponded to a period of fully mature foliage, late in the growing season, and an interval for which chonic effects from 3-4 months of previous exposure of foliage to ozone would be expected be more likely. This was based in part on our previously published studies of ozone effects on growth and water use by individual trees in Tennessee in which effects on seasonal growth patterns were more apparent late in the growing season (McLaughlin et al., 2007).

As discussed in the text, we chose as predictor environmental variables traditional measures of physical climate, temperature, PDSI, and rainfall, that were available at relevant locations across our entire study region. Ozone data were acquired from 4 regional and 1 local monitoring stations to represent the regional air quality within the airsheds in which our 6 watersheds were located. The ozone data were characterized by metrics that decades of air pollution research tell us can be important in defining potentially phytotoxic levels of exposure to ozone. They included averages of both hourly peak concentrations each day, and accumulated exposure doses at and above $60 \mathrm{nl} / \mathrm{l}$, a frequently used threshhold for phytotoxicity (Fowler, 1999),. For all environmental data we used monthly averages over intervals that would most logically influence both biological and physical limitations on water flow through hydrologic pathways from the atmosphere, through processing forests to streams. These were segmented into 2 to 7 month, sometimes overlapping, averaging intervals to capture phenotypic variations expected and found across the $430 \mathrm{~km}$ North -South latitudinal gradient encompassing the 6 study sites.

The combination of 6 primary indicators (3 physical climate and 3 ozone variables) and four product terms to capture drought (PDSI)* Ozone interactions (see SI 2.0), gave us 34 total possible environmental predictors to consider - an excessive number to test en mass with only 26 years of streamflow data. We approached this task by restricting initial analyses to predictor subsets that were determined to most closely correlate with streamflow and by initially 
analyzing ozone and climate data subsets separately to determine which sets of variables were most effective as streamflow predictors. In this process the ultimate model building was done using Best Regression Analysis (Kleinbaum et al., 1998) to identify the best combinations of predictor variables from subsets of 14 or fewer candidates. These were selected from equal numbers of candidate ozone and climate predictor variables to assure equal chances of ozone and climate variables appearing in the final model.

We have conducted numerous tests to validate the statistical validity and predictive capacity of the streamflow models we have developed in this process. The validity of the ozone signal was verified both by determining that models based solely on climate were consistently and significantly improved by the addition of ozone predictor terms and by measuring the effects of removal of ozone variables from the best models developed with both climate and ozone predictors. The Multiple-Partial Correlation Analysis by which we made separate estimates of ozone and climate signals in complete models, which had 7-11 predictor variables, was also used to estimate the influence of model size and complexity on the relative magnitude of estimates of both ozone and climate influences. For both the Walker Branch Watershed (WBWS) and the New River Watershed (NRWS), estimates of both ozone and ozone climate interactions as well as estimates of climate plus climate*ozone interactions steadily improved and stayed in the same relative ratio to eachother as overall model $\mathrm{R} 2$ improved at all levels from $\mathrm{N}=3$ to $\mathrm{N}=11$. For WBWS, estimates of the influences of $\mathrm{O}+\mathrm{O} * \mathrm{C}$ averaged $27 \%$ and increased from $25 \%$ at $\mathrm{N}=3$ to $27 \%$ at $\mathrm{N}=11$. Influences of $\mathrm{C}+\mathrm{C}^{*} \mathrm{O}$ averaged $50 \%$ of $\mathrm{R} 2$ and increased from $42 \%$ at $\mathrm{N}=3$ to $62 \%$ at $\mathrm{N}=11$. Similarly, for NRWS $\mathrm{O}+\mathrm{O}^{*} \mathrm{C}$ influences ranged from $11 \%$ at $\mathrm{N}=3$ to $15 \%$ at $\mathrm{N}=10$, while $\mathrm{C}+\mathrm{C}^{*} \mathrm{O}$ was more stable, ranging from $64 \%$ at $\mathrm{N}=3$ to $62 \%$ at $\mathrm{N}=10$. Thus estimates of contributions of climate and ozone components in the models were rather consistent across models at increasing levels of complexity.

The possibility of overfitting models was also explored by determining that models developed from subsets of the same data were consistent in form and fit to the data. In addition the consistencies in form and fit to watershed flow data across watersheds also support the strength and validity of models developed by these methods of variable definition and selection. Variable subsets identified as important at one watershed worked well at other watersheds. A separate test to estimate relative contributions of annual differences in patterns of ozone and climate to annual differences in flow between the Walker Branch and New River Watersheds identified annual differences in ozone exposure as being relatively more important than differences in climatic factors in contributing to these annual flow differences. 
More detailed descriptions of methodological procedures in these studies can be found in the following sections: Watershed Characteristics and Data Sources (SI 1.0); Intraregional Comparisons of Watershed Flow Characteristics and Environmental Data_(SI 2.0); Historical Ozone Exposures Across the Study Region (SI 3.0); and Estimating the Relative Magnitude of Ozone Effects on Streamflow (SI 4.0).

\section{SI1.0 Watershed Characteristics and Data}

The locations of all watersheds examined in these studies are noted in Figure 1 of the main text. The direction of flow is indicated by area proportional triangles with the downstream apex located at the position of the monitoring stations. The two largest watersheds examined the Upper James ( 525,000 ha) and the New River $(970,000$ ha) were estimated by land cover maps to be at least $75 \%$ in mature second growth forests. The remaining four watersheds were estimated at $>95 \%$ forest cover. All watersheds were typically forested with mixed deciduous forests typically dominated by oaks, hickories, and yellow poplar.

a. Walker Branch Watershed (WBWS), TN - Analysis interval: 26 yrs, 1982-2007. Located at Oak Ridge, Tennessee, this research watershed is comprised of a total of 98 ha of forested hills at $\mathbf{2 0 0 - 3 0 0 ~ m ~ i n ~ e l e v a t i o n . ~ T h e ~ w a t e r s h e d ~ h a s ~ b e e n ~ m a i n t a i n e d ~ a s ~ a ~ l o n g ~}$ term research facility by Oak Ridge National Laboratory (ORNL) for the Department of Energy and its predecessor agencies since 1969. Estimated forest cover is $>99 \%$. Flow, temperature, and precipitation data for 1982-2007 were acquired from the Walker Branch Watershed website: (http://walkerbranch.ornl.gov). Regional Palmer Drought Severity Index (PDSI) data were derived from National Atmospheric and Oceanic Administration (NOAA) for Tennessee Climate Division 6. Ozone data were provided for the Mascot, TN station located approximately $30 \mathrm{~km}$ East of from Oak Ridge. This station is maintained by the State of Tennessee, Division of Air Quality.

b. Little River (LR), TN - Analysis interval: 19 yrs, 1989-2007. The Little River, monitored at Townsend Tennessee, comprises over 28,000 ha (106 square miles) of forest lands located along the western slopes of the Great Smoky Mountains National Park. This watershed ranges in elevation from 200 to $2300 \mathrm{~m}$ and is fully forested. Temperature, precipitation and ozone data for 1982-2007 were provided by Jim Renfro, Air Quality Specialist with the National Park Service from a monitoring station maintained at Look Rock TN. The Look Rock Station is located at $750 \mathrm{~m}$ elevation at ridge crest approximately $30 \mathrm{~km}$ east of the Townsend, stream gauging station. Regional Palmer 
Drought Severity Index (PDSI) data were derived from NOAA for Tennessee Climate Division 6. Streamflow data were obtained from the US Geological Survey (USGS).

c. Cataloochee Creek (CC), NC-Analysis interval: 26 yrs, 1982-2007. The USGS gauging streamflow gauging station for this watershed is at latitude $35^{\circ} 40^{\prime} 02^{\prime \prime}$ and longitude $83^{\circ} 04^{\prime} 22^{\prime \prime}$. The basin drains $127 \mathrm{~km}^{2}$ of steep, mountainous fully forested terrain that ranges in elevation from $749 \mathrm{~m}$ at the gage to $1,876 \mathrm{~m}$. The main channel is perennial with a mean monthly discharge varying from $1.5 \mathrm{~m}^{3} / \mathrm{s}$ during low flow in September and October to $5.7 \mathrm{~m}^{3} / \mathrm{s}$ in March when spring rains combine with snowmelt. Average annual runoff from the basin was $78 \mathrm{~cm}$ from 1934 through 1995 (U.S. Geological Survey, Water Resources Data, North Carolina). Climate of the area is characterized by abundant precipitation and moderate temperatures. Mean monthly air temperatures range from $4^{\circ} \mathrm{C}$ in December to $23^{\circ} \mathrm{C}$ in July at an elevation of $445 \mathrm{~m}$ and $0^{\circ} \mathrm{C}$ in March to $16^{\circ} \mathrm{C}$ in July at an elevation of $1,920 \mathrm{~m}$.

d. New River (NR), VA - Analysis interval: 19 yrs, 1990-2008. The New River Watershed drains approximately 970,000 hectares ( 3768 Square miles) of predominantly forested (>80\% forest) mountain lands in Southwestern Virginia. The stream gauge is maintained by the US Geological Survey at Glen Lynn, VA near the border between Virginia and West VA and approximately $30 \mathrm{~km}$ Northeast of Bluefield, VA. Regional meteorological data for precipitation, temperature and PDSI were derived from NOAA for Virginia Climatic Division 6. Ozone monitoring data were provided for 1990-2008 by the Virginia Division of Environmental Quality (VADEQ) for a rural station near Wytheville, VA. Three sections of the New River, including a 2,212 square miles upper section monitored at Allistonia, VA, the middle section monitored near Radford Virginia (2767 square miles) and the full watershed monitored at Glen Lynn were evaluated with the same basic results regarding the importance of ozone as a contributor to late season streamflow.

e. James River (JR), VA - Analysis interval: 26 yrs, 1982-2007. The upper James River drains a 525,000 ha (2,073 square mile) sparsely populated rural and predominantly forested watershed that derives from eastern West Virginia and West-Central Virginia. The monitoring station (Latitude $37^{\circ} 31^{\prime} 50^{\prime \prime}$, Longitude $79^{\circ} 40^{\prime} 45^{\prime \prime}$ ) at Buchanan, Virginia is approximately $30 \mathrm{~km}$ East of Roanoke, VA. Regional meteorological data for precipitation, temperature and PDSI were derived from NOAA for Virginia Climatic Division 5. Ozone monitoring data were provided for 1982-2008 by the Virginia Division of Environmental Quality (VADEQ) for a rural station in Roanoke County near Roanoke, VA. 
f. Fernow Experimental Watershed (FEW), WVA - Analysis interval: 18 yrs, 1989-2006. This is a USDA Forest Service long term hydrologic research installation established in 1951. It is located in mountainous areas near Parsons, West Virginia on unglaciated Allegheny Plateau with elevations ranging from 533 to 1,112 meters above sea level. The climate is characterized as rainy and cool. Mean annual precipitation is about 1,470 $\mathrm{mm}$ per year, distributed evenly throughout the year. Mean annual temperature is $8.9^{\circ} \mathrm{C}$. Vegetation is dominated by mixed upland deciduous forests. In this study, we used Watershed 4, a small (39 ha) watershed designated as a Control watershed at Fernow. Streamflow has been monitored since 1951 using a V-notch weir. Hourly ozone data were collected on site since 1989.

\section{SI 2.0 Intraregional Comparisons of Watershed Flow Characteristics and Environmental Data}

The watersheds within the study region are linked by generally similar rolling topography, heavily forested cover, and synoptic summer weather patterns dominated by Southwest to Northeast wind flow patterns and occasional area-wide air stagnation patterns. Typical time lapses of less than a week are required for frontal movement across the region. Summer air 
stagnation patterns typically emerge several times each year and result in area wide elevation of ozone, temperature, and haze. Our analyses provided several measures of this regional homogeneity. First, analysis of historical ozone exposure patterns across the region revealed differences in levels of annual exposure at various sites, but similar patterns of fluctuation at all sites (Figure SI 3.1). Linkages of other factors influencing annual variations in flow were also apparent.

A correlation matrix of annual late-season watershed flow at the six watersheds across the common interval of 1992-2006 indicated that flows were generally well correlated across the region, particularly among the largest watersheds. Pearson correlation coefficients typically ranged from 0.49 to 0.90 among flow at larger watersheds. Among smaller watershed, flow at WBWS was well correlated with that at larger watersheds (0.26 to 0.85), while flows at Fernow, the smallest and most northerly watershed were much more weakly correlated with flow at other watersheds ( 0.13 for NR (largest) to 0.49 for WBWS(next smallest)). In general watersheds were similarly influenced by similarities in synoptic weather patterns across this region. In initial exploratory analyses, for example, specific meteorological conditions, including ozone exposure at Walker Branch Watershed (WBWS) at the southwestern end of the region were found to do a surprisingly good job of predicting flow of the 2100 square mile James River Watershed (JRWS) $\left(R^{2}=0.38, p<0.05\right)$. Prediction of flows for the JRWS were substantially improved by considering the specific annual scale meteorology and ozone exposure of that watershed $\left(R^{2}=0.92\right)$, but the significant aspects of the larger regional scale meteorological patterns influenced both watersheds in similar ways.

Table SI2.1 Mean Environmental Data for the Six Watersheds

\begin{tabular}{|c|c|c|c|c|c|c|}
\hline Comparative Environmental Data ${ }^{1}$ & WBWS & LR & $\mathrm{CC}$ & NR & $\mathbf{J R}$ & FEW \\
\hline Ozone (AOT60 in PPMH) & 1.72 & 2.6 & 1.72 & 0.82 & 0.83 & 0.74 \\
\hline Ozone (MxH in PPB) & 68.2 & 67.8 & 68.2 & 59.4 & 58.7 & 58.8 \\
\hline PDSI & 1.47 & 1.43 & -0.05 & 0.34 & 0.26 & - \\
\hline Rainfall (mm/d) & 4.45 & 4.45 & 4.91 & 4.05 & 3.97 & 4.45 \\
\hline
\end{tabular}


1.Data are averages per month for the months May through September averaged over the years; 1990-2006. A site-specific calculation of regional water deficit was used in Place of Palmer Drought Severity Index (PDSI) for Fernow Watershed.

\section{SI 3.0. Historical Ozone Exposure across the Study Region}

The ozone exposure data used in these analyses originated from five locations Look Rock, TN(for Little River); Mascot, TN (for WBWS and Cataloochie Creek): Wythville, VA (for New River); Roanoke, VA (for James River); and Fernow, WV (for the Fernow reference watershed) as described in the text. In Figure SI-3 we have plotted the historical trends in ozone exposure across the region as represented by these watersheds. The exposure metric $\mathrm{O}_{3} \mathrm{AOT} 6 \mathrm{O}_{59}$ presented was identified as' significant in 3 of the 6 watershed models. Figure SI 3 represents two important aspects of ozone exposure within the study region. First, there was a clear gradient in ozone exposure with the highest values in the southwestern region and lowest values for Fernow and the James River Watershed (JRWS). Second, despite differences in levels of exposure, the year to year patterns of relative highs and lows were very similar across the region. These patterns are driven by regional similarities in air stagnation patterns that occur with a relatively high annual frequency across the region (Korschover, 1973).

We have chosen to use an exposure threshold of $60 \mathrm{nl} \mathrm{I}^{-1}$ to represent potential ozone impacts on forest water use, but other indices such as $40 \mathrm{nl} \mathrm{l}^{-1}$, which is a frequent metric in European studies, could also have been used. For comparison purposes, within our study region the seasonal (April through October) total AOT40 and AOT60 values were $34 \mathrm{ul} \mathrm{I}^{-1} \mathrm{~h}$ and $9.6 \mathrm{ul} \mathrm{I}^{-1} \mathrm{~h}$ respectively for WBWS (Mascot, TN) and $25.7 \mathrm{ul} \mathrm{I}^{-1} \mathrm{~h}$ and $4.9 \mathrm{ul} \mathrm{I}^{-1} \mathrm{~h}$ respectively for JRWS (Roanoke, VA). 


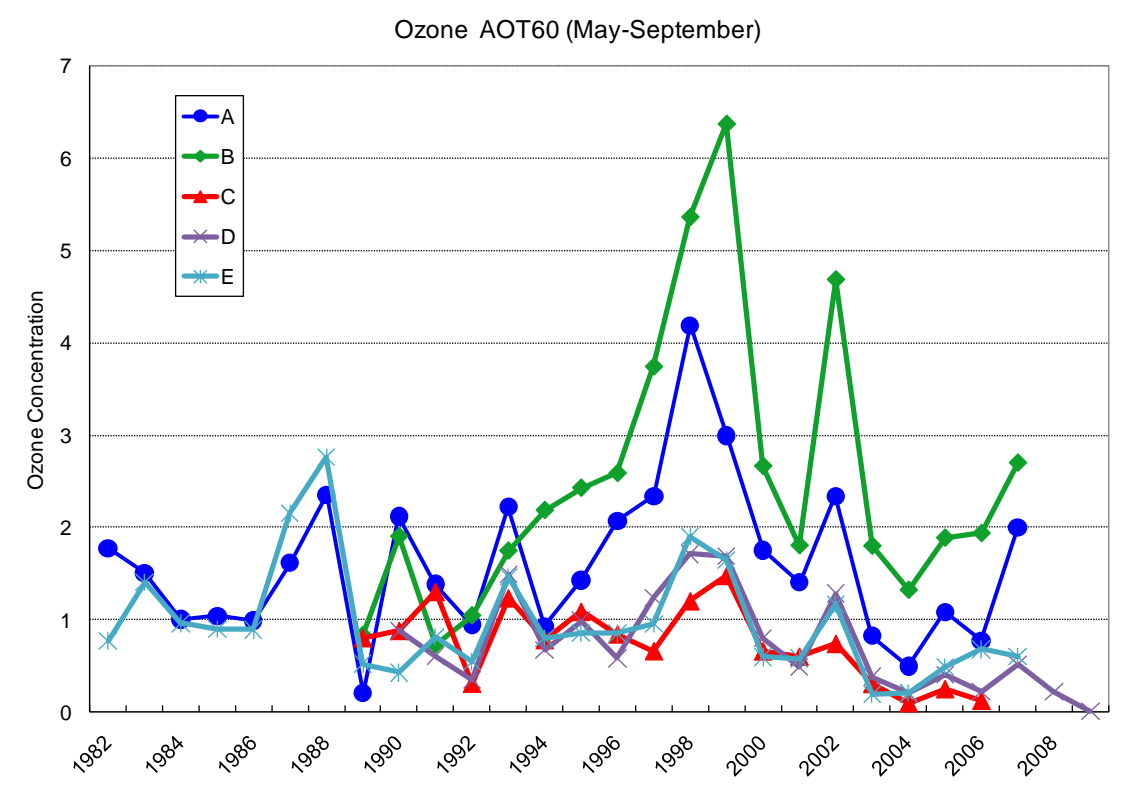

Figure SI3.1a Historical ozone trends for AOT6059 across the study region.

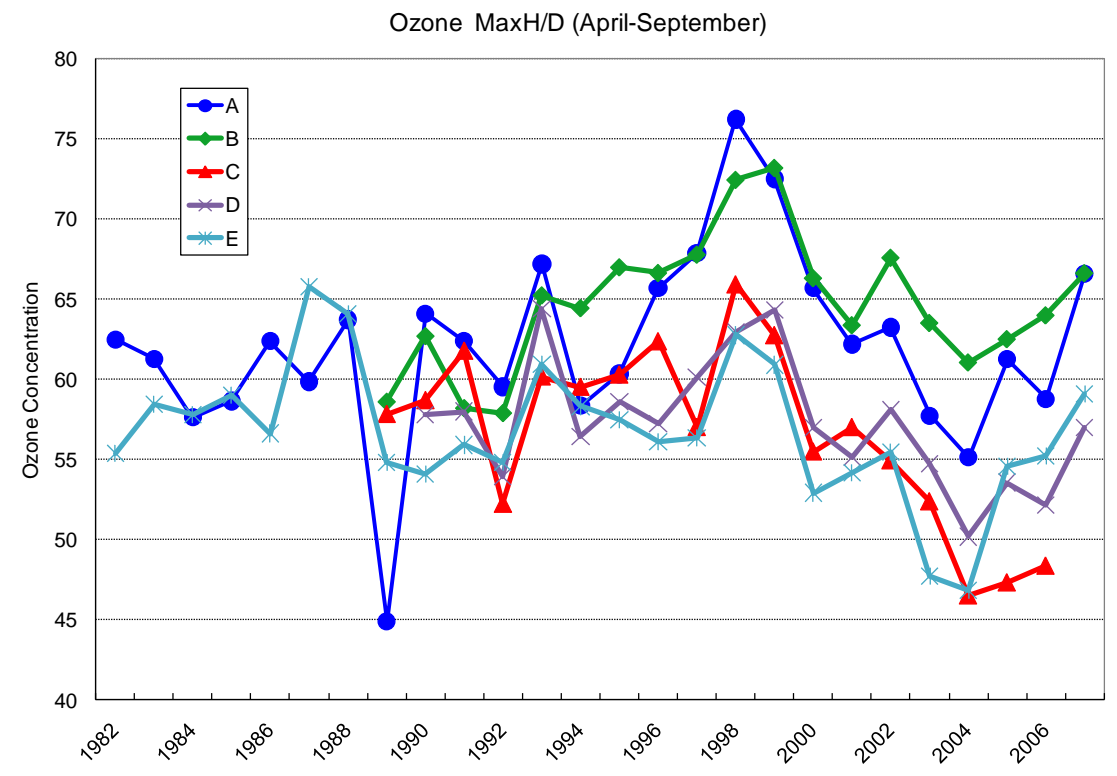

Figure SI3.1b Historical ozone trends for Hourly Maximum per Day across the study region. Where: 
$A=$ Mascot, $T N$ - source for Walker Branch Watershed and Cataloochie Creek

$B=$ Look Rock, TN - Source for the Little River at Townsend, TN

$C=$ Fernow WVA - onsite monitor for Furnow Watershed

D=Wytheville, VA - source for New River AT Gen Lyn, VA

$E=$ Roanoke, VA - source for James River at Buchanan, VA

\section{SI 4.0 Estimating the Magnitude of Ozone Effects on Relative Streamflow}

The Multiple-Partial Correlation Analysis that were presented in Table 4 of the manuscript provide conservative estimates of the percent of the long term variance in annual late-season streamflow that is contributed by annual ozone exposure or climate. The estimate is based on model predictions of actual variance.

To translate that variance into an ozone effect we have first calculated the variance of the time series of late season flow for each watershed and then translated the (\%) ozone effect into a \% of variance ( and flow in CFS).. The magnitude of that effect can then be compared to mean or minimum flow as a relative indicator of the potential of ozone to modify flow characteristics of the watershed. Thus the data shown in Table SI 4.1 combine the flow variance data for each watershed and the estimates of variance attributable to climate and ozone as derived from empirical models of historical flow for each watershed. Estimates of average effects across watersheds ranged from $15 \%-25 \%$ of mean flow for ozone and $8-44 \%$ for climate. Largest effects estimated by this method occurred at the smaller watersheds which are less "buffered" against large relative changes in flow volume by their small and less variable input catchments than larger regional watersheds. Volume flow changes of course are dependent on watershed size. Our analyses indicate that the predominant effect of ozone will be to reduce flow due to increased water use by forests. However it should be noted that in the very highest ozone years an increase in flow might occur if leaf production were reduced or leaf senescence were accelerated (See discussion by McLaughlin et al, 2007b). Nevertheless these figures provide a relative basis for comparing ozone and climate effects to each other across watersheds and over time. 
Table SI 4.1. Estimates of ozone effects on flow of six Appalachian watersheds based on model estimates of contributions of ozone and climate to variance in annual flow. Note that $C^{*} \mathrm{O}$ interactions have been omitted from the individual effects of ozone and climate presented here.

\begin{tabular}{|c|c|c|c|}
\hline Watershed & Component & $\begin{array}{l}\text { Change as a \% } \\
\text { of Mean }\end{array}$ & $\begin{array}{l}\text { Change in Flow } \\
\left(\text { feet }^{3} s^{-1}\right)\end{array}$ \\
\hline Walker Branch & Ozone & 23.3 & 0.057 \\
\hline Oak Ridge, TN & Climate & 21.6 & 0.053 \\
\hline Little River & Ozone & 27.5 & 59.8 \\
\hline GSMNP(W) Townsend, TN & Climate & 7.7 & 16.7 \\
\hline Cataloochie Creek & Ozone & 24.8 & 15.8 \\
\hline GSMNP (E), NC & Climate & 14 & 8.9 \\
\hline New River & Ozone & 17.8 & 487.8 \\
\hline Glen Lynn, VA & Climate & 16 & 438.5 \\
\hline Fernow & Ozone & 26.2 & 0.018 \\
\hline Parsons, WV & Climate & 44.2 & 0.031 \\
\hline James River & Ozone & 14.8 & 175.1 \\
\hline Buchanan, VA & Climate & 21.5 & 254.3 \\
\hline
\end{tabular}

\section{References for Supplementary Information}


Kleinbaum, D.G., Kupper, L.L., Muller, K.E., \& Nizam, A. Applied Regression Techniques.

(Kugeshev, A et al., eds. Duxbury Press, Washington, 1998)

Korshover, J., and Angell, J., A review of air stagnation cases in the eastern United States during 1981-annual summary. Mon. Weath. Rev. 110 (1982) 1515.

Palmer, W.C. Meteorological drought. (US Weather Bureau, Wash.D.C.,1965).

Statistix. 2000. Analytical software for desktop applications. Version 7.0 